Universidade de São Paulo

FaCuldade de Filosofia, Letras e CiênCias Humanas

DEPARTAMENTO DE LETRAS ORIENTAIS

Programa de Pós-Graduação em Estudos Judaicos e Árabes

\title{
A REDE de TELEVISÃo ÁrABE Al JAZEERA: CRESCIMENTO E RELEVÂNCIA NO CONTEXTO LOCAL E INTERNACIONAL
}

\section{Gabriela Santos Lian}

Dissertação apresentada como requisito para aquisição do título de mestre pelo Curso de Pós-Graduação em Estudos Judaicos e Árabes, Faculdade de Filosofia, Letras e Ciências Humanas, Universidade de São Paulo.

Orientador: Prof. Dr. Paulo Daniel Farah

SÃo PAULO 2013 
GABRIELA SANTOS LIAN

A rede de televisão árabe Al Jazeera: crescimento e relevância no contexto local e internacional 
Autorizo a reprodução e divulgação total ou parcial deste trabalho, por qualquer meio convencional ou eletrônico, para fins de estudo e pesquisa, desde que citada a fonte.

Catalogação da Publicação 
Nome: LIAN, Gabriela Santos

Título: A rede de televisão árabe Al Jazeera: crescimento e relevância no contexto local e internacional

Dissertação apresentada à Faculdade de Filosofia, Letras e Ciências Humanas da Universidade de São Paulo para obtenção do título de Mestre pelo Curso de PósGraduação em Estudos Judaicos e Árabes.

Aprovado em:

Banca Examinadora

Prof. Dr. Instituição:

Julgamento: Assinatura:

Prof. Dr. Instituição:

Julgamento: Assinatura:

Prof. Dr. Instituição:

Julgamento: Assinatura: 
À minha avó Nagibe El-Khouri Lian, minha eterna gratidão por dividir comigo seu amor à cultura árabe e seus conhecimentos. 


\section{AGRADECIMENTOS}

- Ao Prof. Dr. Paulo Daniel Elias Farah, por me mostrar os caminhos e me dar o privilégio de aprender tanto com ele.

- $\quad$ Ao Marcelo Bellini Dalio, pelo companheirismo e parceria em todos os momentos.

- $\quad$ À minha irmã Juliana Lian e aos meus pais Maria Tereza e Ricardo Lian por acreditar e incentivar.

- $\quad$ À Dolly Attie Khouri pela co-participação nesse desafio.

- $\quad$ Ao Prof. Luciano Barrionuevo pelas aulas de conversação sobre o tema da pesquisa.

- $\quad$ Ao Embaixador Anuar Nahes e à diplomata Claudia Assaf pela receptividade e papel fundamental na viagem ao Catar.

- $\quad$ Aos funcionários da Al Jazeera Ezzeddine Abdelmoula e Sarah Taha por abrirem as portas e me proporcionarem tantos contatos. Aos amigos Deddah Abdallah, Laith Mushtaq e Stephanie Dötzer, pela hospitalidade em Doha e na emissora.

- $\quad$ Aos colaboradores da TV Globo Caco Barcellos, Marcel Souto Maior, Mariano Boni, Eduardo Acquarone, Jorge Zappia e Maria Thereza Pinheiro pela força. Às chefes Ana Escalada, Mônica Pinheiro e Rosane Batista pelas dispensas providenciais. E aos colegas Fabrício Marta, Ana Paula Brasil, Alexandre Mattoso e Carlos Jardim pela compreensão e apoio.

- $\quad$ Aos amigos do Departamento de Letras Orientais, Luís Henrique Costa e Jorge Luiz Mesquita, pela atenção especial. 
Busque o conhecimento

Ainda que na China.

Hadith (ato e dito) do Profeta Maomé 


\section{RESUMO}

O objetivo principal deste trabalho é analisar o crescimento da Al Jazeera, a rede de TV árabe que mudou a realidade da imprensa no Oriente Médio e em poucos anos se tornou uma das mais vistas no mundo. A rede de TV foi fundada em 1996 em Doha, Catar, durante um período de grandes mudanças no país. Até o ano anterior, um governo conservador limitava os avanços, mas um golpe de Estado levou ao poder o atual Emir, que começou a promover reformas liberais resultando assim em mudanças significativas ao país. A criação da $\mathrm{Al}$ Jazeera era parte de um plano de modernização. Em 2001, o canal árabe ganhou notoriedade quando transmitiu os vídeos de Osama Bin Laden. Desde então, o mundo voltou os olhos para o que estava sendo produzido lá. Em 2006, a emissora lançou um canal em inglês, a fim de mostrar as notícias de uma perspectiva árabe. A pesquisa foi baseada na bibliografia especializada e nos trabalhos teóricos de comunicação que complementam com observações in loco e entrevistas com a equipe da Al Jazeera em Doha. Nesta dissertação, analisam-se o contexto de surgimento da Al Jazerra, a cobertura de algumas guerras e transformações, o surgimento de outros veículos e a criação do canal em inglês com o intuito de compreender o processo de consolidação e expansão dessa rede.

Palavras-chave: Al Jazeera, televisão, oriente médio, árabe, Catar, guerra. 


\begin{abstract}
The main purpose of this paper is to analyze the growth of Al Jazeera, the Arabic TV network that changed the reality of media in Middle East and in a couple of years became one of the world most watched station. The TV network was founded in 1996 in Doha, Qatar, during a great changing time in the country. Until last year, a conservative government restricted the progress, but a coup brought to power the current Emir, who began promoting liberal reforms resulting in significant changes to the country. The creation of Al Jazeera was part of a modernization plan. In 2001, the Arabic channel gained notoriety when broadcasted videos of Osama Bin Laden. Since then, the world turned its eyes to what was being produced there. In 2006, the station launched a channel in English, in order to show the news from an Arab perspective. The research was based on specialized literature review and theoretical works which complement with on ground observations and interviews given by Al Jazeera's staff in Doha. In this thesis, we analyze the context of the emergence of Al Jazerra, covering wars and some social transformations, the emergence of other media and creating the channel in English, in order to understand the process of consolidation and expansion of this network.
\end{abstract}

Keywords: Al Jazeera, television, middle east, arabic, Qatar, war. 


\section{LISTA DE FIGURAS}

Figura 1. Distribuição geral das respostas à pergunta: Quando você assiste noticiário internacional, qual das emissoras de TV você assiste mais frequentemente? Dados em porcentagem. 70

Figura 2. Distribuição entre os diferentes países das respostas à pergunta: Quando você assiste noticiário internacional, qual das emissoras de TV você assiste mais frequentemente? Dados em porcentagem. EAU refere-se aos Emirados Árabes Unidos.

Figura 3. Distribuição geral das respostas à pergunta: Dos canais de notícia que você assiste, qual você assiste mais de cinco vezes por semana? Dados em porcentagem.

Figura 4. Distribuição entre os diferentes países das respostas à pergunta: Dos canais de notícia que você assiste, qual você assiste mais de cinco vezes por semana? Dados em porcentagem.

Figura 5. Veículos de mídia mais citados na Alemanha em 2006. Adaptado de 655 quotes in 39 german opinion leading media such as FAZ, Spiegel, ARD-Tagesthemen. 73

Figura 6. Divisão percentual entre países citados no noticiário da Al Jazeera International e dos principais telejornais noturnos norte-americanos entre novembro de 2006 e janeiro de 2007. Dados em porcentagem. 74

Figura 7. Divisão percentual entre temas citados nas notícias dos principais telejornais noturnos norte-americanos entre Novembro de 2006 a Janeiro de 2007. Dados em porcentagem. 75

Figura 8. Porcentagem que o tema religião foi noticiado na Al Jazeera International e nos principais canais de notícias em diferentes países em fevereiro de 2007. Dados em porcentagem.

Figura 9. Divisão percentual da perspectiva sobre os protagonistas do tema "Religião" da Al Jazeera International e dos principais canais de notícias em diferentes países em fevereiro de 2007. 


\section{LISTA DE APÊNDICES}

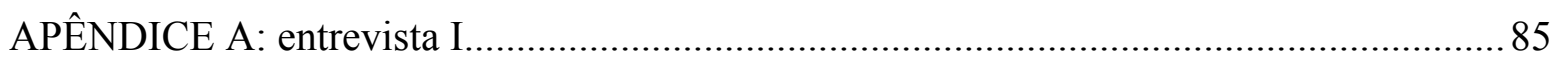

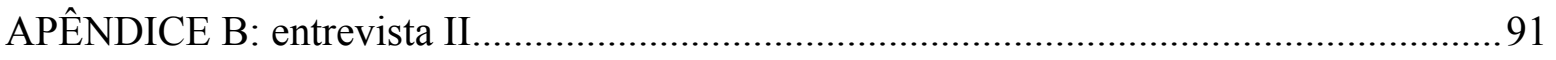

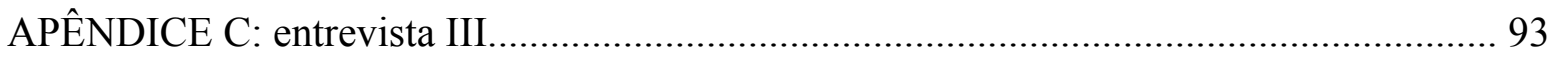

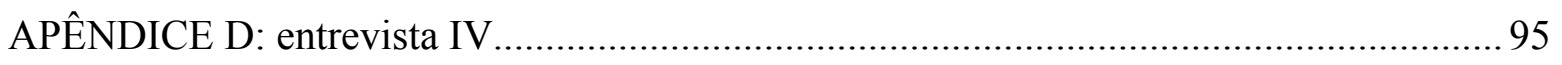

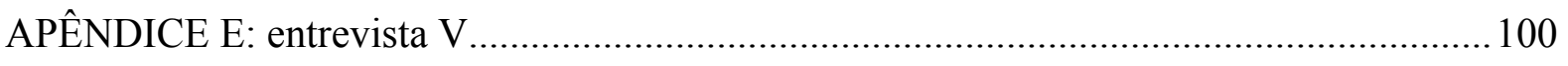

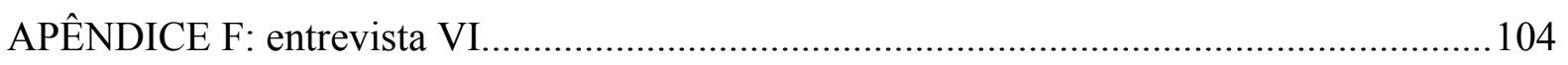

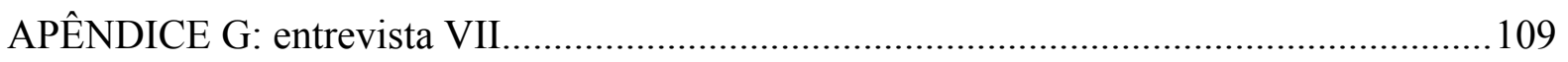

\section{LISTA DE ANEXOS}

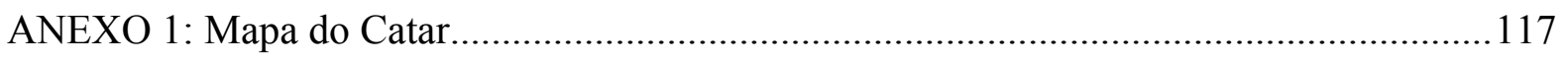

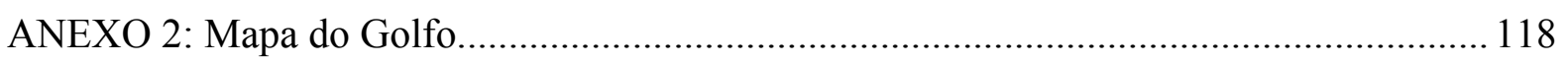

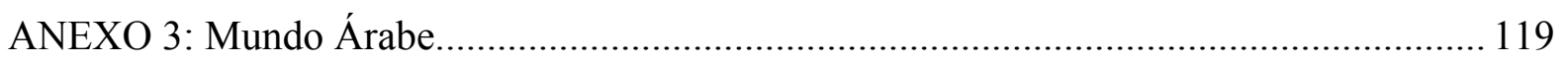


Introdução e metodologia................................................................................... 13

Capítulo $1 \mathrm{O}$ contexto do surgimento da Al Jazeera .......................................... 17

1.1 Aspectos históricos e culturais ................................................................................ 17

1.2 O Catar na antiga era de Xeique Hamad............................................................17

1.3 As transformações e o novo Catar na era do Emir ................................................ 18

1.4 A importância da Xeica Moza nas transformações do país .................................. 19

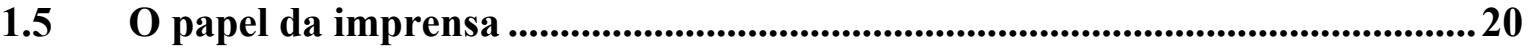

1.6 A chegada da Al Jazeera..........................................................................................21

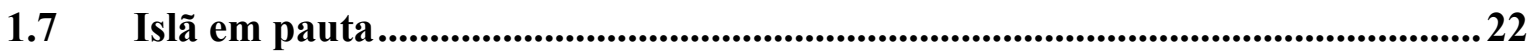

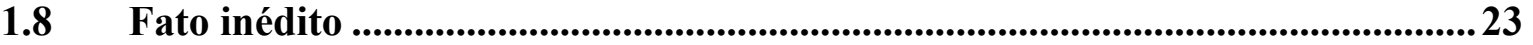

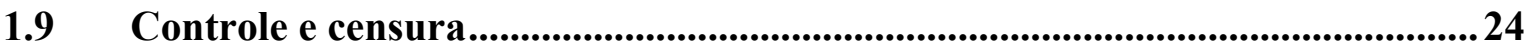

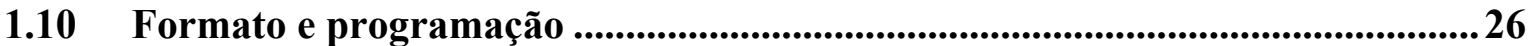

1.11 Polêmica ao vivo ...................................................................................................... 27

1.12 A resistência de uma sociedade conservadora .....................................................28

1.13 O Catar na Al Jazeera ..................................................................................................30

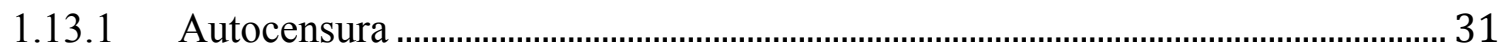

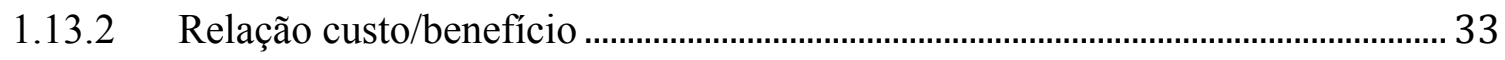

1.14 Bagagem cultural........................................................................................................3 34

Capítulo 2 Cobertura de Guerras ......................................................................... 38

2.12001 - A primeira grande cobertura .......................................................................... 38

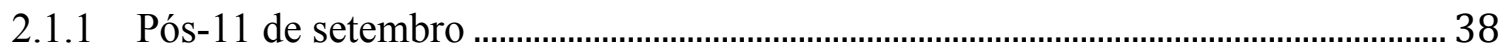

2.1.2 O início da guerra no Afeganistão................................................................................. 39

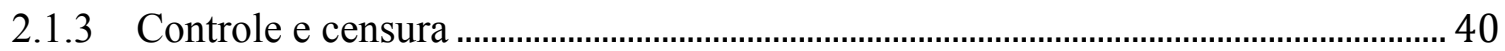

2.1.4 O que foi e o que não foi noticiado ................................................................................ 41

2.1.5 A emissora chamada de porta-voz do terrorismo...................................................... 42

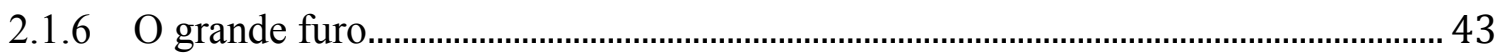




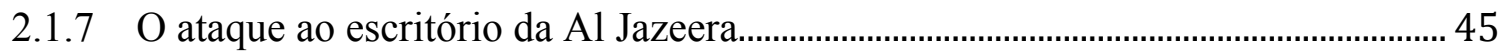

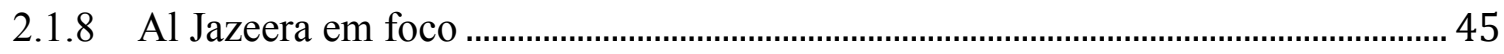

$2.2 \quad 2003$ - A cobertura da invasão ao Iraque ...................................................47

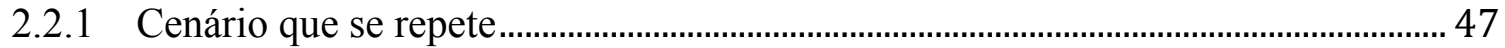

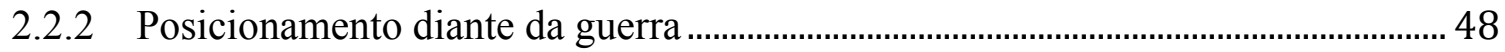

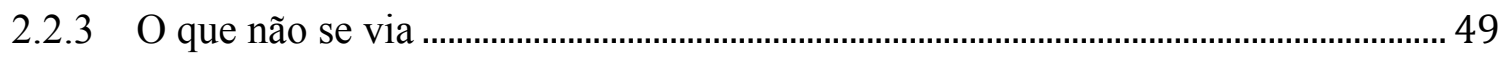

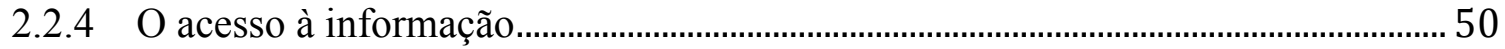

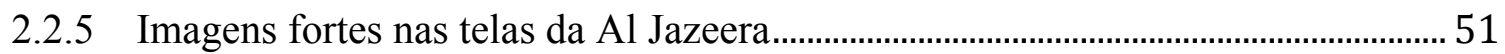

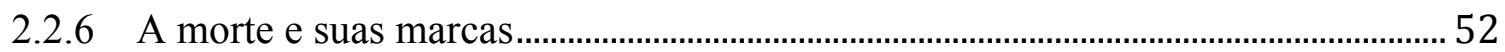

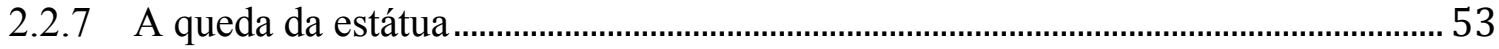

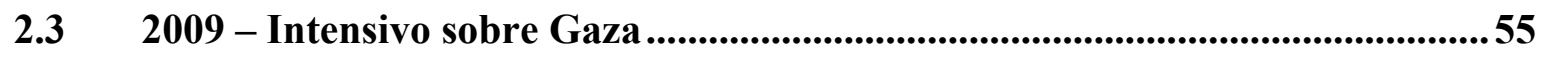

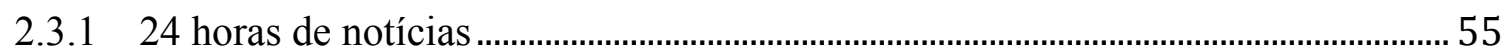

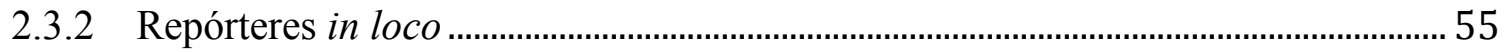

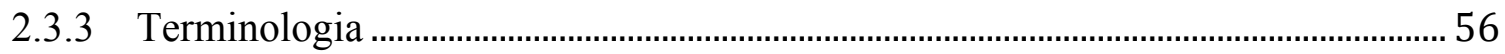

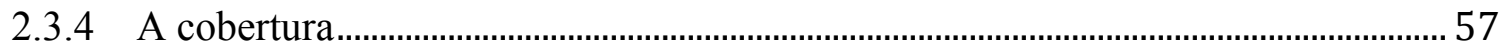

$2.4 \quad 2011$ - O ano da Primavera Árabe ........................................................................58

2.4.1 O início da cobertura da Al Jazeera ............................................................................... 58

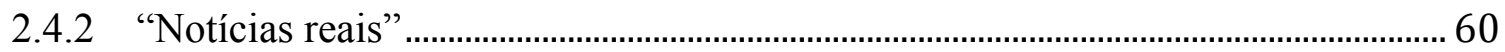

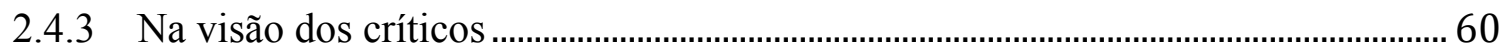

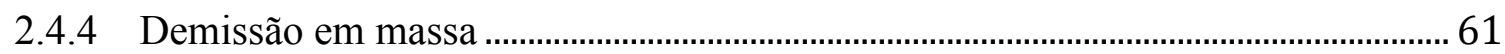

Capítulo 3 A consolidação da Al Jazeera e o surgimento de outros canais no

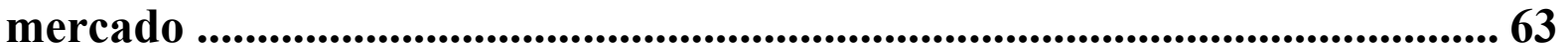

3.1 Comemoração dos 10 anos de Al Jazeera ..........................................................63

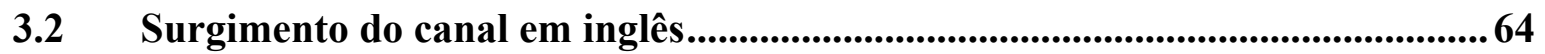

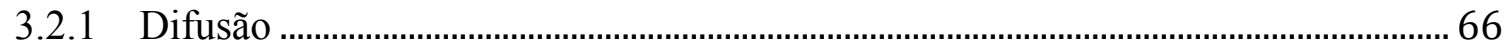

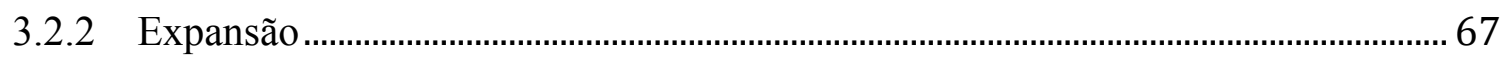

3.3 Repercussão: similares pelo mundo...................................................................68

$3.4 \quad$ Pesquisas de audiência .............................................................................................69 6

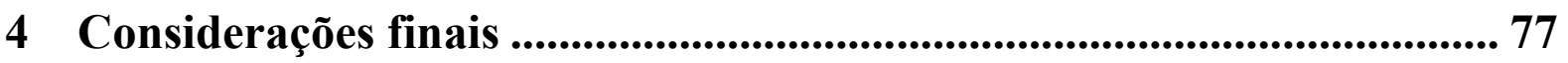




\section{Introdução e metodologia}

De acordo com a Declaração Universal dos Direitos Humanos adotada pela Organização das Nações Unidas (ONU), "todo mundo tem direito à liberdade de opinião e de expressão". Mas o que é adotado pela ONU pode não ser adotado pelo resto do mundo. Esse princípio, por exemplo, foi completamente ignorado e ficou distante da realidade de boa parte do Oriente Médio. Em algumas regiões, a imprensa, que deveria ser ferramenta para o debate de ideias, sempre foi usada como veículo pelo qual os governos imprimem ordem sobre seu povo. Nestes locais, a mídia informativa tendenciosa ficou caracterizada pelo que se chama de "supremacia da censura".

A Primavera Árabe, como ficou conhecida a onda de conflitos e protestos no mundo árabe em 2011, foi o estopim da insatisfação geral da população em relação às políticas repressivas dos governos ditatoriais. Uma onda revolucionária percorreu o norte da África e o Oriente Médio na tentativa de chamar a atenção da comunidade internacional para todos esses anos de repressão e censura na mídia, na internet e nas ruas de países árabes.

Durante muitos anos, o jornalismo que se via no mundo árabe estava muito distante da produção ocidental e intimamente ligado à política local. Nos países mais fechados, as reportagens institucionais pró-governo eram as únicas que circulavam. A agenda dos governantes era sempre a principal notícia do dia e dificilmente se discutia sobre os problemas daquela região. Para se informar sobre o que estava acontecendo no mundo, o cidadão árabe era obrigado a recorrer aos meios de comunicação internacionais, que geralmente produziam o noticiário da Europa e da América, predominantemente em inglês.

Em 1996, houve uma mudança nesse cenário quando uma nova emissora surgiu na pequena península do Catar. A Al Jazeera (“a ilha”, como podemos traduzir o nome dado a ela) começou a transmitir notícias, opiniões e pontos de vista a partirde uma perspectiva árabe. Os governantes do país acreditaram na ideia e fundaram o canal de televisão que iria revolucionar a imprensa do Oriente Médio.

Nesse período, o país passava por uma grande transformação. Até o ano anterior, um governo conservador limitava avanços, mas com o golpe de Estado e ascensão do atual Emir ao poder, algumas reformas trouxeram significativas mudanças para a região.

O Catar é um país que vem ampliando sua presença no cenário internacional e buscando um 
papel de liderança na região apesar de suas dimensões territoriais reduzidas. Exemplos que demonstram esse esforço incluem sediar concertos internacionais, eventos esportivos de renome como Campeonatos Internacionais de Tênis, Atletismo e Futebol, rodadas comercias, e o maior evento de todos, a Copa do Mundo de 2022.

A escolha por parte da Federação Internacional de Futebol (FIFA) aconteceu em dezembro de 2010, quando se candidataram também países europeus, entre eles Inglaterra, Portugal e Espanha, Estados com tradição no esporte. O nome do Catar causou surpresa, uma vez que o país sequer participou de uma Copa do Mundo. Também será o primeiro da Liga Árabe a receber tal competição.

A criação da rede de televisão (TV) Al Jazeera também era parte do plano de modernização. Com o lema "a opinião e a outra opinião", a emissora assume em sua essência que veio trazer polêmica. Quando um tema está em discussão, a pluralidade de opiniões precisa existir para o enriquecimento do debate. Os mais tradicionais desgostam da ideia, pois acham que a razão merece mais espaço e a discordância deveria ser desprezada. É natural que divergências apareçam quando há diferentes pontos de vista, sendo difícil saber quem está certo e quem está errado.

As opiniões sobre a TV Al Jazeera são controversas. Vários a descreveram como antiárabe, antijudaica e antiamericana. Muitos regimes vizinhos ficaram furiosos com as políticas da empresa. Por outro lado, ela se tornou a voz de quem antes nunca havia falado. Trouxe os dois lados da notícia, quebrando a tradição da imprensa árabe de servir a um único interessado.

Contudo, o canal árabe foi crescendo e em 2001 ganhou notoriedade quando divulgou vídeos de Osama Bin Laden. Desde então, o mundo voltou os olhos para o que era produzido e veiculado ali. Em 2006, a emissora lançou um canal em inglês, a fim de transmitir um noticiário com o ponto de vista árabe, mas destinado a atingir também aqueles que não dominam o idioma. Na comemoração de seus 10 anos, ela já havia se tornado uma das maiores emissoras de TV do mundo.

O sucesso que fez a partir daí ocasionou a quebrado monopólio jornalístico de décadas da imprensa ocidental. Houve um grande fortalecimento desse tipo de linguagem e também um incentivo ao aparecimento de outros veículos com propostas bastante parecidas. O surgimento da emissora fomentou uma concorrência até com os grandes líderes do mercado mundial de notícias. 
Assim, a Al Jazeera tem mudado a realidade dos meios de comunicação no Oriente Médio e das pessoas em todos os países árabes. A importância dela na revolução árabe é evidente: por meio do canal, toda a população passou a ter contato com a diversidade. Ela tem contribuído para o desenvolvimento da imprensa árabe à medida que estabelece um novo paradigma para o jornalismo profissional. Ao passo que a emissora conseguepromover a discutição de ideias e temas polêmicos, o debate na região deixa de ser conservador ou até proibido e passa a ser natural, mesmo com assuntos antes considerados tabus.

Só o fato de a TV Al Jazeera ter se tornado em tão pouco tempo uma das emissoras mais influentes do mundo já valeria um trabalho de pesquisa em qualquer país. Aqui no Brasil isso se faz ainda mais importante, uma vez que quase não há bibliografia sobre o tema em português. Um estudo inédito no meio acadêmico contribui para mostrar a realidade desta região e como o canal se adaptou ao cenário internacional para transmitir sua mensagem.

A pesquisa também poderá ser aproveitada para outras análises referentes à mídia televisiva de maneira geral e à cultura árabe, hoje tão miscigenada com a cultura brasileira. No Brasil, vivem atualmente cerca de 16 milhões de árabes e de descendentes de árabes. Essas pessoas compartilham as tradições e pensamentos passados de geração para geração, mesmo que o aprendizado da língua tenha se perdido ou esteja menos difundido.

É importante considerar que este trabalho leva em conta a efemeridade da TV. A ideia de fazer a análise de uma óptica mais ampla e sem tanto rigor para reportagens eleitas ou para um produto específico dentro do canal é proposital. A produção televisiva corre contra o tempo por dois motivos: o primeiro é que cada jornal tem um espaço pré-determinado e precisa colocar no ar, independentemente da relevância, os acontecimentos do dia; o segundo é que a notícia exige imediatismo e a necessidade de colocar rápido no ar se sobrepõe - muitas vezes não há tempo para que o material exibido seja trabalhado como os profissionais gostariam - e, assim, seria injusto fazer um julgamento minucioso.

O objetivo deste trabalho consiste em fazer um mapeamento da história da rede de TV, descrevendo os fatores que contribuíram para seu crescimento, a fim de responder à pergunta: o que faz da Al Jazeera a Al Jazeera? Em outras palavras: o que fez dessa emissora uma das maiores do mundo? Ou: o que ela tem de novo, de que forma mudou a realidade das pessoas no Oriente Médio, quais foram suas contribuições para aquela região?

A ideia é identificar os traços que ela inscreve na cena contemporânea e de que maneira tem alterado o cenário da região. Por meio da descrição de sua história, do levantamento de dados, 
descrição de coberturas relevantes e da discussão sobre a identidade cultural do canal, pretende-se abrir caminho para pesquisas futuras que aprofundem ainda mais o tema.

Este trabalho contempla entrevistas com colaboradores da Al Jazeera e conhecedores do assunto que a acompanharam desde sua estreia na TV (ver entrevistas nos anexos). A pesquisa de campo ocorreu em Doha, no ano de 2009, na sede da Al Jazeera, onde foi possível observar a cultura e as relações no Golfo, além de acompanhar a forma de trabalho dos profissionais envolvidos nas coberturas do canal. A visita à Universidade do Catar contribuiu para acrescentar à pesquisa uma análise acadêmica sobre o tema e a bibliografia em que esta obra se baseia.

É importante deixar registrado que a transcrição das entrevistas é literal e que os erros gramaticais foram mantidos uma vez que não interferem na compreensão do conteúdo. Este trabalho tem como base uma bibliografia especializada no assunto e por isso recente, além de obras de teóricos conhecedores das identidades culturais que compõem o objeto da observação e descrição feitas aqui.

O primeiro capítulo desta dissertação versa sobre o contexto de surgimento de Al Jazeera e aspectos históricos, culturais e sociais do Catar.

No segundo capítulo, aborda-se a cobertura de guerras, entre as quais aquela sobre o pós-11de setembro e a guerra no Afeganistão, a invasão do Iraque, a ofensiva sobre Gaza e a Primavera Árabe.

O terceiro capítulo analisa a consolidação da Al Jazeera e o surgimento de outros veículos no mercado, o décimo aniversário dessa rede e a criação do canal em inglês, entre outros temas. 


\section{Capítulo 10 contexto do surgimento da Al Jazeera}

\subsection{Aspectos históricos e culturais}

Menos de um milhão de habitantes vivem na península que ocupa um espaço vinte vezes menor do que o território ocupado pelo estado de São Paulo. Um pedaço de terra infértil, desértico e dependente de recursos estrangeiros se destaca entre os países da região e atualmente chama a atenção do mundo todo.

O Catar, um pequeno país que fica no Golfo Arábico, ao lado da Arábia Saudita e dos Emirados Árabes Unidos, é uma monarquia sem instituições eleitas democraticamente ou partidos políticos e sempre foi considerado um dos mais conservadores de todo o mundo árabe. E é esse país que agora salta aos olhos de quem olha o mapa e tenta entender como vem dali tanto barulho. Para compreender corretamente todas as mudanças e seus resultados, é preciso concentrar as atenções no Catar e em sua história.

As transformações no Catar começaram a ter relevância no noticiário internacional em 1995, quando o Emir Sheikh Hamad Bin Khalifa Al Thani assumiu o governo do Catar. Sua família, os Al Thani, é a maior das famílias governantes no Oriente Médio e é conhecida por seu caráter argumentativo. Entretanto, as transições de um governante para outro nunca foram fáceis. Nesse caso, o poder foi tomado por meio de um golpe militar.

\subsection{O Catar na antiga era de Xeique Hamad}

O antigo emir era o pai do Xeique Hamad - Sheikh Khalifa Bin Hamad Al Thani -, que assumira o cargo mais alto da monarquia logo após a independência do país, em 1972. Ele ficou no comando do governo por aproximadamente 23 anos. Foram tempos de importante desenvolvimento no que diz respeito à infraestrutura, à política interna e externa e à criação de um Estado moderno.

Mas foi nesse período, segundo Hugh Miles, que o Catar se firmou como uma quase extensão da Arábia Saudita, cúmplice que era do mesmo conservadorismo e compartilhando a mesma política que mantinha fechado o país. A família Al-Thani emergiu graças ao movimento religioso do wahabismo, vertente do islamismo criada na Arábia central que influenciou o ambiente político e cultural da história do Catar. 
O que contribuiu muito para que o desenvolvimento e o conhecimento ficassem restritos por alguns anos foi a ideia de que o Catar deveria se limitar, em todos os sentidos, para não ameaçar a soberania dos países vizinhos, como acreditava o Xeique Khalifa Bin Hamed Al Thani. "Apesar de ter uma fenomenal reserva de gás natural, o antigo Emir acreditava que os interesses do Catar não seriam atendidos se o país evoluísse à frente dos outros da região, cultural, econômica e politicamente falando" (MILES, 2005, p. 15).

Seu filho mais velho, o primeiro de cinco, teve contato com um governo considerado democrático em uma viagem a Londres, quando ainda era criança. A democracia era tão distante de sua realidade que esse conceito lhe pareceu ridículo, tanto que teve um ataque de riso assistindo a um debate no Parlamento. Depois, esse mesmo garoto voltou à Inglaterra, onde permaneceu até 1977. Seu contato com o ocidente e com as informações que circulavam na Europa foi crucial para que houvesse uma valorização do conhecimento, para que a modernização se tornasse um objetivo e viesse a desencadear uma série de mudanças alguns anos depois. No seu retorno ao Catar, em 1977, assumiu o cargo de ministro da Defesa.

Durante anos, esse filho mais velho viu o pai abusar dopoder e agir arbitrariamente de acordo com seus caprichos. Dizia-se que o xeique gostava muito de viajar, e nos últimos anos de governo, passava mais tempo na Riviera francesa do que no comando do país. Foi na volta de uma dessas viagens internacionais, em 1995, que o xeique depôs o primeiro ministro e colocou outro no lugar.

O filho, incomodado com tamanho autoritarismo e temendo que o pai pudesse fazer o mesmo consigo, usou a sua influência de ministro da Defesa, deu um golpe e assumiu o poder. Contase que o xeique estava em Genebra e soube pelo rádio o que fez o próprio filho.

\subsection{As transformações e o novo Catar na era do Emir}

Desde 27 de junho de 1995, é o Emir Sheikh Hamad Bin Khalifa Al Thani quem governa o país. Aos 44 anos, ele se tornou o mais jovem na história do Golfo a conquistar o poder estatal, já que o histórico na maioria dos países da região era de governantes de 60, 70 e até 80 anos de idade, muitos com mais de 25 anos de mandato. O novo emir e sua equipe pertenciam a uma geração diferente, mais aberta à política e às idéias do ocidente.

Sua chegada provocou uma reviravolta no panorama que os catarianos estavam acostumados a ver. Influenciado pelo contato que teve com a democracia da Europa e dos Estados Unidos, 
o novo emir rompeu com a tradição e ousou uma espécie de revolução na linha de pensamento que vinha conduzindo a política do país até então. Adepto da privatização, ele transformou instituições estatais de serviço antiquado e, como qualquer gestor sensível, desenvolveu bom relacionamento pessoal com seus subordinados de confiança.

Também houve uma série de mudanças nas leis, entre elas a criação de eleições municipais e a introdução de eleições democráticas para alguns cargos e assuntos. Foi em 1999 que aconteceram as primeiras eleições da história do Catar. Apesar disso, é importante ressaltar que a constituição do país é mais influenciada pela religião do que pela participação do público e que essa participação em algumas decisões é um bom começo. No entanto, ela ainda é muito incipiente e está longe de ser significativa para grandes mudanças na política do país.

Não obstante, vale enfatizar que o Catar ainda não é uma democracia. O emir não é um tirano, mas tem o poder sobre tudo e não é eleito pelo povo. A oposição não é tolerada e ainda não há um debate verdadeiro sobre como o país tem sido governado. Com uma palavra, o Emir pode mudar a vida de qualquer indivíduo ou família no Catar - mesmo de poderosos. Em 5 de agosto de 2003, o Emir anunciou que seu sucessor não seria mais seu irmão, mas seu quarto filho e, assim, em um único momento, sua decisão mudou a história do país para sempre.

\subsection{A importância da Xeica Moza nas transformações do país}

Nessa nova política de mudanças, o papel da mulher foi rediscutido. No Catar, a grande maioria das mulheres usa véu e vive de forma muito tradicional. O conservadorismo era tamanho que, antes do novo governo, elas não tinham os mesmos direitos dos homens perante a Justiça. Elas passaram a ter o direito a voto, o que parecia muito estranho para os cidadãos catarianos, mesmo já no início do século XXI. Elas agora também trabalham e, desde 1999, concorrem a cargos políticos (a primeira vez nos países do Golfo). A sociedade que antes oprimia muito as mulheres passou a dar um espaço para elas. Também houve mudanças no papel da mulher no campo educacional.

Um dos nomes mais importantes nessa questão é o da Xeica Moza bint Nasser al-Misned, a segunda das três esposas do emir. A importância de uma mulher na diplomacia do país é um aspecto muito particular do regime de Xeique Hamad e novidade na região, já que as discussões políticas nos países árabes e as exposições públicas sempre se restringiram ao universo masculino. Foi necessário um certo tempo até que sua figura pudesse ser divulgada: fotografias da Xeica Moza eram proibidas - até que ela apareceu em uma entrevista ao lado 
do marido para a surpresa do mundo árabe. Desde então, passou a ser presença constante na mídia e em eventos políticos.

A esposa do emir participa na política do país e contribui muito para o impulso das mulheres rumo à universidade. Agora cada vez mais frequentadas pelo sexo feminino, as universidades representam mais do que a liberdade à informação, representam a reaproximação da sociedade ao conhecimento. A educação pública para mulheres tornou-se tão importante que elas passaram a ser maioria na Universidade do Catar.

Xeica Moza é responsável pela Fundação do Catar para Educação, Ciência e Desenvolvimento Social e integra muitos outros comitês. Algumas vezes, fala em público com plena autoridade enquanto seu marido a assistesentado na plateia. Ela mostra autoconfiança e trabalha para melhorar a situação das mulheres árabes, que ainda sofrem preconceito no Catar. Ela também trabalha em favor dos direitos humanos das crianças, pois acabou com a corrida de camelos que usava trabalho infantil, por exemplo.

Juntos, o emir e a primeira-dama de formação ocidental decidiram concentrar esforços para fazer do Catar um líder em educação. Desde então, o tema se tornou obsessão para o casal. Diversas universidades de prestígio demonstraram interesse em abrir campus no Catar e instalaram unidades suas no país. Além disso, o presidente da Universidade do Catar integra o grupo de governo, de modo que as decisões da academia podem ter preferência, ainda que esteja entre ministros.

\subsection{O papel da imprensa}

Diferentemente de outros governantes árabes, o novo emir criou o hábito de explicar boa parte de suas políticas e ideias falando diretamente com a imprensa. Quando ele decidiu abandonar a política conservadora do pai de se manter atrás dos vizinhos, fazendo o possível para elevar a posição do Catar no mundo, também passou a fazer de tudo para que o país se tornasse conhecido e noticiado.

Assim surgiu a ideia de criar um canal de notícias na televisão árabe que fizesse um jornalismo parecido com o dos grandes canais internacionais, mas de um ponto de vista árabe. A proposta era a de um canal que estivesse mais próximo do que se podia ver em países da Europa e nos Estados Unidos em termos de qualidade, com o mesmo estilo de produção das TVs dominantes no mercado, como CNN, BBC, Fox, entre outras. Esse canal, aparentemente, 
até poderia ter a cara e o formato do ocidente, mas teria que se posicionar de outra maneira diante dos fatos.

O jornalista Ayman Gaballah, chefe de redação, relembrou o início do processo:

Dia após dia, mês após mês, ano após ano, fomos descobrindo que o desafio era maior do que tínhamos pensado. Não é para copiar a imprensa ocidental, não é para fazer réplicas da imprensa ocidental com sabor árabe ou cultura árabe ou perspectiva árabe. Não! Nosso sonho não existe em lugar nenhum do mundo [...] Talvez a imprensa ocidental estivesse mais perto do que pensamos naquela época, em 1996 (GABALLAH, 2009).

Gaballah disse que quando se deparou com determinadas questões ocidentais, descobriu que o Ocidente lidava com alguns assuntos do mesmo jeito que os governos árabes abordavam suas questões. "Não há liberdade, há apenas um ponto de vista exibido na tela, não há tolerância em ouvir a outra opinião. Então nós descobrimos que o sonho que procurávamos estava longe demais, então tivemos que alcançar nosso próprio caminho" (GABALLAH, 2009). O novo projeto tinha o objetivo de promover liberdade para tratar de todas as pautas de interesse coletivo. E a grande estratégia para conseguir fazer um jornalismo diferenciado na região seria noticiar apresentando todos os lados da notícia, dando oportunidade para cada corrente apresentar suas ideias, dando voz para quem nunca tinha sido ouvido. Dessa forma, segundo o ideal do Emir, conseguiria atingir o maior número possível de árabes no mundo, chamando ao passo que atrairia a atenção para seu próprio país.

\subsection{A chegada da Al Jazeera}

Foi em 1996 que aconteceu a mais efetiva de todas as mudanças no país e que resultou em tantas outras transformações: a criação da Al Jazeera, um canal de TV completamente diferente de tudo o que já tinha sido visto ali.

$\mathrm{O}$ canal árabe da $\mathrm{BBC}$, que funcionou por muito pouco tempo, havia sido fechado alguns meses antes, o que deixara desempregados 250 jornalistas árabes, com experiência em transmissão de notícias e administração de mídia. "Eles estavam de repente fora do sonho de fazer a diferença no mundo árabe, produzindo jornalismo em um padrão melhor” (MILES, 2005, p. 33). A Al Jazeera procurou-os. Ao receberem o convite, 120 deles aceitaram.

A história da imprensa nos países árabes mudou como um todo quando surgiu uma rede de televisão árabe, sediada em pleno Golfo, com árabes no comando, que transmitia notícias em árabe, com alto padrão de qualidade. Aproximadamente $25 \%$ dos funcionários eram catarianos, os outros pertenciam a diversas nacionalidades do Oriente Médio. 
O repórter Mohammed Val afirmou que a linha editorial foi muito importante para construir a história do canal.

A Al Jazeera criou sua política editorial não para evitar dar todos os pontos de vista de um conflito, e isso é o que a distinguiu da CNN e BBC, porque a $\mathrm{CNN}$ e a BBC tendem sempre a dar um único ponto de vista: o ponto de vista dos governantes ocidentais. As histórias da Al Jazeera são sempre complexas, o que significa que são cheias de ângulos. (VAL, 2009).

\subsection{Islã em pauta}

As atividades e práticas religiosas, como o mês sagrado do Ramadã e a anual peregrinação a Meca, eram notícias relevantes para a Al Jazeera. Em seus boletins e transmissões interativas com a data da reportagem, o uso do calendário islâmico é adotado e aparece antes do calendário gregoriano. O fuso horário de Meca é citado antes do horário de Londres. Nota-se que havia uma preocupação com a cultura do Islã, que contrastava com a cobertura ocidental dessa temática (BARKHO, 2006).

A linguagem adotada pelo canal também mostrou porque os árabes e muçulmanos tem mais empatia e apreço pela Al Jazeera do que por emissoras como BBC, CNN e Fox News. Cada palavra, cada expressão ou forma de se referir a um grupo, a um lugar, a um conceito, é previamente pensada e escolhida como maneira mais apropriada de fazer as referências, demonstrando respeito à cultura árabe.

O mesmo não se vê em outros canais pelo mundo. Desde o 11 de setembro de 2001, quando os Estados Unidos sofreram um ataque promovido por um grupo de extremistas islâmicos, os muçulmanos têm sido retratados na imprensa internacional de forma generalizada.

Generalizações indevidas caracterizam, na maioria das vezes, a visão que o Ocidente tem do islamismo; e vice-versa. Supostos especialistas, que nunca estiveram nas sociedades que analisam nem jamais abriram o Alcorão, contribuem para uma interpretação quase sempre enviesada dos vários mundos muçulmanos. Quem foi a dois ou três países dessa órbita compreende que eles são bastante diversos. (FARAH, 2001, p. 10).

As discussões em torno do assunto se estendem e levam em consideração a forma como é retratado o Oriente e o Ocidente.

O novo cenário das relações entre o Ocidente e o Oriente encontra a popularização dos meios de comunicação de massa. As considerações e análises feitas especialmente sobre o Islã passam a extrapolar as fronteiras da academia e dos especialistas e - especialmente nos momentos de crise são levados ao programa de talk show da televisão (MORAES, 2011, p. 29). 
Em seu livro Covering Islam, lançado em 1981, Edward Said analisa a representação domuçulmano no trabalho da imprensa. Na versão revisada, lançada em 1997, ele constata que o foco nos muçulmanos aumentou nesses 15 anos na imprensa americana e ocidental, sobretudo carregado de uma exagerada hostilidade e beligerância já previstas em 1981.

Generalizações maliciosas sobre o Islã tem se tornado a última aceitável forma de denegrir a cultura estrangeira no Ocidente; o que tem sido dito sobre a mente muçulmana, ou caráter, ou religião, ou cultura como um todo não pode ser dito nas discussões tradicionais sobre africanos, judeus, outros orientais ou Asiáticos (SAID, 1997, pág. 12)

\subsection{Fato inédito}

Além de toda essa abordagem diferenciada, a Al Jazeera tinha uma proposta inovadora: "ser ponte entre culturas, sustentando o direito ao conhecimento, reforçando os valores de democracia e o respeito às liberdades e direitos humanos" (TV AL JAZEERA SATELLITE NETWORK, 2007, p. 210). As palavras com que ela se vendia para o mundo causavam estranheza naquele contexto. "Democracia", "liberdade" e "direitos humanos" eram conceitos pouco presentes na realidade dos cidadãos habitantes do Golfo, ou até desconhecidos.

A valorização de opiniões divergentes não existia na região. No ocidente, o jornalismo sempre esteve acostumado com a presença de mais de um lado da notícia na cobertura de um fato. Parece óbvio dizer que uma reportagem tem que procurar ouvir todas as pessoas envolvidas e dar oportunidade para pessoas de opiniões diferentes se expressarem. No oriente, porém, ver uma emissora atuar como um fórum de pluralidade era realmente inédito. A novidade causou surpresa para os quehabitavam esses países conservadores.

Antes da Al Jazeera nós não tínhamos imprensa assim nos países árabes, no mundo árabe. Antes, só havia mídia oficial. E só. Não se viam pessoas comentando nas ruas, não se podia ver na TV o povo falando sobre os assuntos. A Al Jazzera colocou você e eu, minha mãe e minha família e todo mundo sentando em uma sala assistindo e discutindo sobre política, religião, tudo. Isso é novo, disse o cinegrafista iraquiano Laith Mushtaq (MUSHTAQ, 2009).

O novo emir, quando assumiu o trono, veio com ideias novas. Ele percebeu que para avançar teria que se comunicar bem com seus cidadãos e que a educação era ferramenta primordial para que essa relação fluísse bem. Desde então, os catarianos presenciaram mudanças radicais com a reforma e passaram a ser mais educados e politicamente mais bem informados do que antes. 
Albert Hourani em Uma história dos povos árabes, quando reflete sobre a cultura nacional das décadas de 1940 e 1950, afirma que a criação de uma elite educada através do ensino superior era um processo que tinha começado muito antes em alguns países árabes.

As mudanças na sociedade, e entre elas a chegada ao poder de uma elite nacional, levaram a uma rápida disseminação da educação. As exigências da vida nas cidades tornavam tanto mais necessárias a alfabetização e a aquisição de qualificações; os governos nacionalistas empenhavam-se na construção de países fortes, e isso envolvia o uso de todas as potencialidades humanas; governos centralizados modernos precisavam comunicar-se com seus cidadãos mais plenamente do que fora necessário antes (HOURANI, 2006, p. 508).

A modernização da imprensa estava nas prioridades do emir para estreitar a relação com o povo e fazer o país avançar. O investimento na nova imprensa, especialmente na Al Jazeera, era uma via de mão dupla: além de mudar a maneira como os cidadãos de lá veem o resto do mundo, mudaria drasticamente a aparência do Catar internacionalmente.

No mundo árabe de forma geral, as altas taxas de analfabetismo ainda dificultam o acesso à informação de qualidade à população. O noticiário televisivo torna-se assim ainda mais relevante ao conseguir informar pessoas que não tiveram acesso à educação e não conseguem ler uma manchete de jornal. Segundo Barkho, a predominante tradição oral nos 22 estados árabes é o que faz da televisão a principal fonte de informação, uma vez que basta ouvir e assistir às imagens, em contraponto à leitura exigida pela imprensa escrita (BARKHO, 2006).

\subsection{Controle e censura}

Ao divulgar imagens impressionantes e informações sobre os conflitos, a Al Jazeera levava os fatos para todo o mundo árabe e islâmico. As imagens televisivas transcenderam fronteiras e chegaram até casas, escritórios e cafés, do Oriente Médio, do norte da África, passando por pequenos vilarejos da Indonésia até o Paquistão. E não precisava ser letrado para saber o que estava acontecendo. "A Al Jazeera fez uma revolução na mídia árabe”, disse Muhammad Jasimal-Ali, diretor-geral na época (TV AL JAZEERA SATELLITE NETWORK, 2007, p. 24).

Apesar da novidade, essa não foi a primeira vez que o mundo árabe ficou eufórico por uma nova mídia. Jornais locais existem desde o século XIX, o rádio desde a Segunda Guerra e a transmissão televisiva chegou logo depois. Com a Guerra Civil no Líbano (1975-1991), muitos meios de comunicação se mudaram para a Europa, o que deu espaço para a imprensa saudita. 
O problema dessa abundante imprensa sempre foi o controle do Ministério da Informação, cujo foco principal é servir aos interesses do governo. Os meios de comunicação são monitorados de perto, quando não controlados pelo regime. $\mathrm{O}$ todo poderoso e onipresente Ministério é responsável por isso e está em muitos desses países até hoje, e a figura do ministro, grande conhecido no mundo árabe, existe para controlar ou censurar o conteúdo de notícias produzidas (MILES, 2005).

Os jornais e as TVs acabavam se concentrando em transmitir a agenda do xeique, emir ou presidente naquele dia e celebravam entediantes datas nacionais. Era toda uma dedicação do noticiário televisivo com fatos pouco relevantes para a população. A mídia também era usada para medir a opinião dos cidadãos sobre determinado assunto, com debates nos jornais, antes de uma decisão do governo.

Como se esperava, os árabes aprenderam a desprezar o que liam, viam ou escutavam pelos noticiários e a desacreditar na informação dos meios de comunicação. A imprensa era considerada uma parte do governo, que só transmitia e nunca investigava ou criticava o que vinha de seus líderes. O que deixava os árabes em contato com as notícias do mundo eram a Radio Monte Carlo, a Voz da América e a BBC - todas em árabe, mas ocidentais e, por isso, objetos de suspeita.

Boa parte do espaço das primeiras páginas ainda está dominada por fotografias de membros do regime recebendo autoridades estrangeiras ou desempenhando funções de Estado. Os eventos do calendário governamental sempre são notícia e o dia-a-dia dos grandes líderes tem destaque especial. Os canais de TV também usam horas e horas de sua programação exibindo música, dança e filmes.

[Foi] a primeira vez que um canal no mundo árabe não começa seus boletins de notícias ou seus noticiários com as atividades do presidente em vigor. $\mathrm{E}$ essa foi a grande mudança que fizemos desde o primeiro dia, porque não fizemos isso. Nós começamos dando notícias reais, desde o primeiro minuto (VAL, 2009).

A presença de notícias com enfoque crítico sempre foi raridade na imprensa árabe e só existia quando os olhares voltavam-se para fora das fronteiras, para a terra dos outros. Reportagens investigativas e exposições de mau comportamento entre as elites dominantes quase nunca eram publicadas nos diferentes veículos de mídia do Oriente Médio. 


\subsection{Formato e programação}

A televisão é um formato que, de alguma forma, limita o aprofundamento das questões apresentadas. Por exigir dinamismo, as redes de TV dificilmente dão espaço para reportagens mais longas. Apesar de ser este seu meio de comunicação, a Al Jazeera investiu no conteúdo e inovou na densidade permitindo um mergulho nos temas.

Dessa forma, a emissora árabe contraria essa premissa. A programação é focada nas notícias, mas também cede espaço para os debates em torno dos assuntos do momento. Quando os outros canais da própria rede surgiram, os assuntos ficaram ainda mais específicos. A variedade de programas, além do noticiário factual, permite reflexões mais elaboradas dos temas em questão. Por vezes as emissoras internacionais não dão oportunidade para esse aprofundamento e isso foi um diferencial da Al Jazeera.

Foram os programas de entrevista e debate que fizeram, em um primeiro momento, o nome da Al Jazeera. Um dos programa mais conhecidos chama-se "Mais de uma opinião" e conta com uma discussão ao vivo entre convidados. "Sem fronteiras" é um programa de entrevistas. "Super secreto" é de documentários que sempre investigam assuntos controversos. "Diálogo aberto" coloca um grupo de dez ou doze pessoas do público contra o convidado. "Só para mulheres", programa sobre temas femininos.

Em "Direção oposta", o apresentador coloca, ao vivo, um tema polêmico para dois convidados debaterem ao passo que o público pode ligar para se manifestar durante a discussão. É o mais radical e revolucionário, considerando-se que o discurso livre nos países árabes é algo raro. Alguns acreditam que o programa é um passo para a democracia, outros só enxergam uma competição de gritaria. O apresentador Al-Qasim é a alma do debate, colocando questões de modo que os convidados respondam da forma mais radical possível, e já recebeu inúmeras acusações de colaborar com serviços de inteligência de países estrangeiros (MILES, 2005).

"Religião e vida" é um programa que discute a vida moderna sob a perspectiva islâmica. O Xeique Yusufal-Qaradawi, que exerce um papel fundamental no programa, orienta sua fala de acordo com seus conhecimentos do Alcorão. Ele foi exilado do Egito por ser membro da Irmandade Muçulmana, que por décadas se opôs ao governo egípcio, e se radicou no Catar, tendo já servido porvezes aos interesses do Estado, inclusive ao conferir legitimidade religiosa às políticas sociais do novo emir. Sua flexível interpretação do livro sagrado dos 
muçulmanos contrasta com o conservadorismo ainda presente na Arábia Saudita e no Afeganistão.

Não levou muito tempo, no entanto, para que os programas de debate da Al Jazeera gerassem controvérsia. A primeira delas ocorreu com "Direção oposta", em que a o governo jordaniano foi publicamente criticado por uma convidada, de modo que o escritório da emissora em Aman teve que ser fechado, tamanho o desentendimento diplomático desencadeado. Outros tabus também eram quebrados quase toda semana. "Religião e vida" foi mais um programa que causou polêmicas.

Durante toda a programação, a filosofia de "uma opinião e outra opinião" ganhava peso. O seu criador diz que foi assim que a Al Jazeera mostrou como pretende trabalhar: ouvindo os árabes e a oposição árabe. Jamil Azar, que além de ser apresentador de notícias e membro do grupo editorial do canal, ajudou desde o começo na criação da Al Jazeera, conta que essa atitudede conceder voz à oposição sobre todos os assuntos foi revolucionária na imprensa árabe e em um país árabe.

\begin{abstract}
Nós queríamos ser imparciais e balanceados porque eles também são parte da cena, os israelenses são parte da cena na região. Acho que ainda aderimos a isso até agora [...] Antes da Al Jazeera havia apenas uma opinião em toda discussão e era a opinião dos governantes do regime. Quando nós chegamos, nós introduzimos a outra opinião e foi um grande passo para a imprensa árabe (AZAR, 2009).
\end{abstract}

\title{
1.11 Polêmica ao vivo
}

Ao dar espaço para as mais distintas vozes e opiniões, a Al Jazeera se destacou entre todos os outros meios de comunicação. A ideia, segundo o porta-voz da emissora, era mesmo apresentar ao telespectador árabe os diversos lados da história bem argumentados e deixá-lo se posicionar como quisesse. O debate entre pessoas com pontos de vista diferentes trouxe outra realidade para a região. Em Voices of the New Arab Public, Marc Lynch afirma que os novos argumentos públicos eram abertos e sem restrição e defende que nos programas de entrevista é preferível uma alta intensidade de argumentação a uma visão oficial do debate para acalmar a discussão. (LYNCH, 2007).

Foi a primeira vez que um israelense falou em uma rede de TV árabe, e em hebraico, o que deixou boa parte da população perplexa e a outra parte revoltada. $\mathrm{Na}$ Al Jazeera, judeus e palestinos discutem ao vivo, o que significa não poder editar, não poder evitar que vá ao ar o que foi dito. No exato momento em que um argumento é proferido, milhões de pessoas 
sintonizadas assistem e assimilam. Concordando ou não, governantes e telespectadores ouvem o que o outro tem a dizer e não podem fazer nada a não ser continuar a discussão com quem estiver por perto.

A política de entrevistar israelenses era mais um diferencial da Al Jazeera em relação aos outros canais árabes, e por esse comportamento ela recebeu severas críticas. O emir do Catar foi acusado de proteger os sionistas e seus aliados, assim comoà emissora acusava-se de ser uma "ferramenta dos sionistas que espalha os que contribuem para esse tumor chamado Israel” (MILES, 2005, p. 93). A Al Jazeera desafiou ao continuar com seu lema, ao dar aos israelenses a chance de falar. Antes dessa política, muitos árabes sequer tinham ouvido a voz de um israelense.

O slogan da emissora "a opinião e a outra opinião" tem tudo a ver com essa questão e é assim que ela se vende. A emissora chama a atenção para a valorização de opiniões distintas em uma mesma notícia.

O que distingue a Al Jazeera não é simplesmente a variedade de assuntos e a natureza dos tópicos que aborda, mas também a multiplicidade de pontos de vista que almeja para entreter, enquanto reflete cada tom da opinião árabe e islâmica nunca antes considerada tão importante (ZAYANI; SAHRAOUI, 2007, p. 62).

Levando em consideração todo esse cenário, pode-se dizer que o Catar teve um grande impulso no sentido das liberdades de expressão e civis. Para os padrões ocidentais, liberdade de expressão e de imprensa ainda são severamente restritas ali. Crítica pública à família real ou ao Islã permanecemproibidas. O mesmo vale para participações em organizações que criticam o governo. Mas a redução às restrições, como por exemplo a abolição do Ministério da Informação em 1996, fez com que o país ficasse bem à frente dos demais da região.

Nós permitimos que eles (árabes) conversem não apenas com nossos apresentadores, mas com nossos convidados, nos nossos programas, ao vivo, no ar, eles podem telefonar e fazer suas colocações, expressar suas opiniões. Isso é algo que foi uma novidade na imprensa árabe. Nós ainda fazemos isso, pessoas podem telefonar e dialogar com nossos convidados e colocar suas questões. E é por isso que falaram por aí que nós aparentamos ser um parlamento árabe no ar (AZAR, 2009).

\subsection{A resistência de uma sociedade conservadora}

Um dos fatores que explica por que as mudanças chegaram ao Catar antes de a outros países árabes é a dimensão do país. É mais fácil mudar um país pequeno do que um país grande, porque se atinge a sociedade como um todo mais rapidamente. Ainda assim esta 
transformação não foi nada fácil. As mudanças causaram alguns desconfortos por uma série de razões.

A primeira delas é devido ao fato de que trazer novas ideias não é algo bem vindo em uma região tão conservadora. A militância islâmica não tem força política significante no Catar, diferentemente de muitos outros países no Golfo. Entretanto, há muitos radicais islâmicos tradicionalistas que se opõem às novas reformas introduzidas pelo Xeique Hamad.

Vale destacar que nem todos ali anseiam pela democracia: muitos deles estão felizes com o atual sistema e acreditam que a democracia não funcionaria bem. Os catarianos mais conservadores temem que as reformas estejam acontecendo rápido demais.

Outro motivo é o estremecimento de algumas relações internacionais. A radical reforma do Catar de forma geral tem sido bem vista pelo ocidente, mas é rejeitada por quem está muito perto. Os catarianos e os sauditas não têm, particularmente, um relacionamento amistoso. Apesar de os dois países compartilharem o conservadorismo wahabita, o Catar é mais moderado e tolerante, ainda que para padrões ocidentais possa parecer conservador demais. Além disso, os sauditas acreditam serem os mais fortes do Golfo, o que incomoda os outros países da região, principalmente os catarianos, que têm renda per capita maior.

Por causa desse ambiente tradicional, a Al Jazeera chocou a opinião pública do Oriente Médio e por isso sofreu censura internacional por anos. Foi quando vieram as críticas dos vizinhos: “o perigo provocado pelo canal é maior do que o da imprensa ocidental, cujos pensamentos nós já conhecemos", disseram (MILES, 2005, p. 51). Em posse das informações sobre os acontecimentos, o povo árabe, pela primeira vez, fez seus autocráticos líderes terem que defender suas políticas e decisões. Alguns países tentaram obstruir o sinal de transmissão do canal (MILES, 2005).

As críticas vinham de toda parte: a Arábia Saudita acusou a Al Jazeera de envenenar a opinião pública com as coisas que divulgava e até de ter a BBC por trás. Um jornal saudita afirmou que a emissora interferia nas relações internacionais dos países. Nas mesquitas, as acusações eram de corromper a moral árabe. As reações no país eram no sentido de proibir qualquer contato com funcionários da empresa ou banir os produtos que viessem dali.

Virou lugar-comum dizer que a Al Jazeera era o "canal suspeito". Os simpatizantes de sua ideologia eram acusados de ter ligações com Saddam Hussein, com Osama Bin Laden e até com Israel. Entre israelenses, a crítica era de ser anti-israelense ou árabe nacionalista. 
Entreseculares, de ser islamista. O canal era suspeito de ser fundado por Osama Bin Laden, por Saddam Hussein e até pela CIA, o que provocou sérias repercussões diplomáticas.

No Kuwait, as críticas também eram duras. O incômodo era motivadopelo fato de o telespectador que ligava poder fazer suas colocações sem ser interrompido, o que, para eles, indicaria a política de atingir o Kuwait. O ministro da Informação chegou a voar até o Catar para fazer seu protesto pessoalmente. $\mathrm{O}$ emir explicou que era uma companhia autônoma e responsável por suas decisões editoriais e que ele não podia fazer nada. Ele passou a sofrer pressão de líderes árabes que exigiam uma intervenção política sobre a Al Jazeeraque a submetesse dentro das tradições regionais.

Jordânia e Egito também tiveram atritos com o Catar por causa da transmissão do novo canal árabe. O único governante árabe que não polemizou sobre a Al Jazeera foi Saddam Hussein. Ele calculou que tinha mais a ganhar com o canal sematacá-lo. Os outros todos a acusaram de ser pró-Iraque, pró-Israel, militante islâmica, agente do governo britânico, pedaço do governo catariano. Os embaixadores árabes em Doha disseram que passaram tanto tempo preocupados com a emissora que se sentiam embaixadores de uma TV e não de um país.

Em dezembro de 1998 a União de Transmissão dos Estados Árabes se expandiu como parte da nova política de liberar a imprensa árabe do controle do governo. Todas as rádios e estações de TV privadas foram convidadas, menos a Al Jazeera, já que todos tinham que mostrar compromisso com os princípios da mídia árabe e respeito à Liga Árabe. O recado era claro: para fazer parte do grupo, a Al Jazeera teria que se comportar.

\subsection{O Catar na Al Jazeera}

Também crescia a insatisfação com o fato de que a Al Jazeera não analisava o regime catariano criticamente como fazia com os vizinhos. Dizia-se que ela vinha sendo mordaz contra a maioria dos regimes árabes, mas raramente olhava para dentro de seu próprio território. A política nacional pouco aparecia nos jornais da emissora, salvo algumas exceções.

O conflito entre Hamad Bin Khalifa e seu pai deposto não teve atenção. Além disso, a decisão do emir em 2001 de adiar eleições parlamentares por dois anos sem nenhuma justificativa passou sem ser noticiada. Em resposta, as autoridades do canal argumentaram que o Catar é 
uma pequena nação com pouca notícia e que qualquer evento local fica atrás das questões que envolvem todo o Oriente Médio e das notícias do mundo.

O Catar é um país muito pequeno, e a maioria das pessoas aqui não é catariana, como eu. Eu não sou catariano. E os catarianos que estão envolvidos com a política do país são minoria. Se você pensar sobre isso, há muito pouco desenvolvimento e notícias gerados no país. [...] De qualquer maneira, se houvesse alguma notícia do Catar que valesse a pena difundir, nós a difundiríamos. Visitas de líderes e conferências mundiais no Catar nós cobrimos. Fora isso, podemos falar sobre muito pouco. Especialmente, não se esqueça de que somos uma sociedade tribal aqui, e os catarianos são muito leais aos emir. Portanto, quase não há problema, quero dizer, não há nenhum problema (AZAR, 2009).

Os críticos questionavam: Se a Al Jazeera deixa de noticiar o Catar por ser um país pequeno, como justificar a cobertura de eventos no Bahrein, um pequeno estado insular, bem menor do que o Catar? Os dois países já tiveram divergências ao longo de sua história, os barenitas inclusive protestaram contra a decisão do Xeique Hamad de criar eleições municipais. A questão colocada é se a política interna do Bahrein tem mais relevância do que a do Catar. O que chama a atenção é que a Al Jazeera recebeu figuras de oposição ou vozes dissidentes de cada país árabe, exceto do Catar. A explicação da emissora de que o Catar é um país pequeno, com poucos cidadãos, e que por isso não merecia ser notícia não convencia quem estava incomodado com sua política.

Mohammed El-Nawawy e AdelIskander defendem que, graças a Al Jazeera, os catarianos já sentiram o gosto da liberdade de expressão, mas, quando o assunto se volta para as questões internas, eles não veem nada mais do que as cansativas relações públicas do governo.

No Oriente Médio, existe um questionamento crescente e um pedido de mudança. A ausência de uma cobertura séria da política do Catar na programação da Al Jazeera levou governantes árabes a ver a emissora e seu país de origem como hipócritas (EL-NAWAWY; ISKANDAR, 2003, p. 89 tradução nossa).

\subsubsection{Autocensura}

O cuidado excessivo ao fazer referências à família real e aos assuntos internos do Catar tem uma consequência bastante grave: a autocensura. Apesar de o governo ter diminuído as restrições à liberdade de imprensa, os jornalistas continuam exercendo algum tipo de controle sobre eles mesmos, se rendendo à pressão de manter a boa imagem do emir perante o mundo (EL-NAWAWY; ISKANDAR, 2003). 
O repórter Mohammed Val disse que nunca sofreu censura neste canal, diferentemente de quando trabalhou em outros veículos.

Antes de trabalhar na Al Jazeera, eu atuava na imprensa escrita, e é claro, trabalhava em alguns países onde não se pode dizer tudo. No Marrocos, na Mauritânia, em alguns desses países existem muitos assuntos em que não se pode tocar, muitos tabus. Mas na Al Jazeera, aqui, muito poucos assuntos são tabus (VAL, 2009).

Val diz que o Islã é um assunto sagrado e falar sobre isso de um ponto de vista crítico poderia comprometer a carreira de qualquer um: "Você não fala sobre religião, você não profere blasfêmias. Isto não é imposto a você, nós temos nossos próprios limites, nós temos nossa própria autocensura".

O mesmo acontece no meio universitário. Não há controle do conteúdo programático, mas também não há prescrição legal para liberdade, de modo que muitos professores acabam restringindo as críticas e os questionamentos que poderiam fazer.

Para o professor da Universidade do Catar Dr. Mahmoud Hammoud, há sim alguns questionamentos no canal árabe que poderiam desagradar o emir:

Os eventos ditam o que eles divulgam. Algumas vezes eles mostram algo com o qual provavelmente a família real catariana não está satisfeita, mas eles mostram. As pessoas falam na Al Jazeera o que significa que a Al Jazeera divulga livremente (HAMMOUD, 2009).

Não obstante, ele considera a escolha de quem evita tocar em determinados assuntos:

Agora, uma coisa chamada autocensura eu não sei com que frequência acontece porque algumas vezes as pessoas não estão cientes disso. No geral, eles não interferem na política editorial da Al Jazeera (HAMMOUD, 2009).

Uma das explicações de os assuntos políticos catarianos passarem ilesos pelas críticas na Al Jazeera é que isto faz parte de um esforço de não manchar a reputação emergente de um estado progressivo. Contudo, não há dúvida de que há inúmeras questões relevantes para serem noticiadas e discutidas no Catar. $\mathrm{O}$ fato de que os cidadãos só podiam ter TV a cabo, cujos canais tinham que ser previamente aprovados pelo governo catariano, era uma delas. Os críticos também apontariam o despotismo no governo, a falta de eleições parlamentares e a inexistência de uma lei de imprensa que gerencie o relacionamento entre a mídia e o governo.

As linhas entre o governo e Al Jazeera são difíceis de ser desenhadas. Apesar de a empresa ter sido criada e financiada pelo maior governante do país, ele garante que não interfere na conduta editorial do canal. O canal acredita que essa relação é clara e se define como uma emissora fundada indiretamente pelo Estado, mas livre para dizer o que quiser, como outras no plano internacional. Como Mushtag disse em entrevista informal: 
Nós fazemos o melhor para apresentar as notícias e ser honestos às pessoas e transferir o que acontece à nossa volta. Ninguém me obriga como cinegrafista a gravar isso ou não gravar aquilo. E se algum dia alguém disser isso pra mim eu me demito porque eu me recuso. Nós não criamos as coisas. Nós apenas gravamos tudo o que está acontecendo à nossa volta para servir à nossa audiência (informação verbal).

O comando da nova emissora está nas mãos do emir, mas ele garante que os jornalistas não têm restrição alguma por isso. Assim diz o Xeique Hamad Bin Thamer Al Thani, presidente de rede Al Jazeera:

Tudo começou quando a decisão certa foi tomada, aliando recursos humanos, técnicos e financeiros. O que transformou esses componentes em um projeto pioneiro foi a liberdade desfrutada pela redação da Al Jazeera. Apesar de que outras redações na região têm variado os graus de liberdade, o da Al Jazeera se mantém inatingível. Se alguém estava procurando por um segredo por trás de nossa experiência única, seria a distância que separa as decisões políticas e financeiras da redação de notícias (TV AL JAZEERA SATELLITE NETWORK, 2007, p. 9).

\subsubsection{Relação custo/benefício}

A emissora sempre precisou da ajuda financeira do emir, enquanto esta estudava outros meios de se tornar independente. Para ajudar em seu início, o Xeique Hamad deu à Al Jazeera 137 milhões de dólares. O fundo seria para cobrir as despesas dos cinco primeiros anos, quando, pelas projeções iniciais, a emissora já teria atingido independência financeira como algo de valor comercial (MILES, 2005).

Como qualquer outro canal de notícias, o plano era gerar renda através da venda de espaço publicitário, programas e imagens exclusivas, bem como aluguel de equipamentos para outras estações de notícias. Mas não foi isso o que aconteceu. A Al Jazeera falhou na tentativa de atingir rendimento próprio.

A renda obtida com publicidade no canal ficou comprometida em função dos desgastes diplomáticos. A Arábia Saudita é o poder econômico dominante na região, seguida pelo Kuwait, e controla uma grande rede de jornais, revistas, agências de notícias e agências de publicidade. A empresa que gerenciava os comerciais da Al Jazeera era saudita e cancelou o contrato em 1999 - suspeita-se que ela tenha se rendido às pressões do governo saudita. A verba para anúncios vem majoritariamente de empresas sauditas, muitas vezes aconselhadas pelas autoridades do país a não anunciar na Al Jazeera.

Mas a liberdade para lidar com a notícia não tinha preço e contribuiu para reafirmar as transformações no mundo árabe por meio da informação. 
Satélites árabes provavelmente fizeram mais para o mundo árabe do que qualquer movimento crítico organizado poderia fazer, abrindo o espaço público, dando aos cidadão árabes uma oportunidade nova de autoafirmação (LYNCH, 2007, p.29).

E essa liberdade foi o que atraiu tantos jornalistas da extinta BBC árabe, que até então moravam na Inglaterra, para o Catar. As diferenças culturais que chamaram a atenção no início até poderiam prejudicar a permanência de alguns naquele novo cenário se a abertura para que o mesmo jornalismo fosse feito ali não existisse.

\subsection{Bagagem cultural}

Enquanto jornalistas de todo o mundo eram atraídos para o Catar, a audiência era atraída para Al Jazeera. Se levarmos em conta que a maneira com que a notícia é interpretada pode mudar de uma pessoa para outra e que a diferença varia consideravelmente quando duas diferentes culturas estão envolvidas, podemos entender melhor porque os árabes mostravam sua preferência pela emissora aos grandes canais internacionais produzidos no ocidente, como CNN, BBC e Fox.

Leon Barkho avalia que leitores, ouvintes ou espectadores compreendem as notícias quando eles ligam a informação do texto às suas prévias informações ou conceitos que já possuíam anteriormente (BARKHO, 2006). Em outras palavras, as notícias são interpretadas pelos espectadores com base em sua bagagem cultural.

No caso dos árabes e dos muçulmanos, mais do que outras nacionalidades ou religiões, seus repertórios estão profundamente enraizados em sua formação cultural.

E por anos os árabes foram obrigados a confiar na interpretação estrangeira (principalmente ocidental) dos conflitos que aconteciam em seu próprio quintal, ou na sua própria imprensa restrita e controlada que difundia as opiniões dos seus governantes. Al Jazeera deu-lhes aparentemente a oportunidade de ver a sua própria cultura com seus próprios olhos (BARKHO, 2006, p. 3).

Um diferencial que logo atraiu os olhos dos telespectadores foi o idioma. O árabe é falado, sobretudo, em dois continentes, por todo o norte da África, passando pela Península Árabe até o Golfo. É a língua oficial de 22 países, falada por mais de 350 milhões de pessoas, uma das dez mais faladas no mundo. Presente ao longo de todas as fronteiras árabes, ela é um ponto comum entre tantas nacionalidades, apesar de toda a diversidade cultural. Apesar disso, havia muito pouco de jornalismo de qualidade em árabe. A Al Jazeera soube usar essa ferramenta. 
Uma característica presente nos falantes de língua árabe, que pode ser visivelmente encontrada em repórteres e apresentadores da Al Jazeera, é o aspecto expressivo. O sujeito, e aqui podemos incluir entrevistados e comentaristas, deixa sua execução oral ser influenciada pela carga emocional do contexto. Mikhail Bakhtin, quando escreve sobre os gêneros do discurso, explica que a intenção da entonação muda completamente o sentido do que será dito:

A entonação expressiva é um traço constitutivo do enunciado. No sistema da língua, isto é, fora do enunciado, ela não existe. Tanto a palavra quanto a oração enquanto unidades da língua são desprovidas de entonação expressiva. Se uma palavra isolada é pronunciada com entonação expressiva, já não é uma palavra mas um enunciado acabado expresso por uma palavra (BAKHTIN, 1997, p. 290).

O teórico Stuart Hall faz referência ao trabalho de Ferdinand Saussure para examinar a questão da língua na identidade do sujeito:

A língua é um sistema social e não um sistema individual. (...) Falar uma língua não significa expressar nossos pensamentos mais interiores $\mathrm{e}$ originais; significa também ativar a imensa gama de significados que já estão embutidos em nossa língua e em nossos sistemas culturais (HALL, 2006, p. 40).

O mesmo autor questiona o que está acontecendo com as identidades culturais na modernidade tardia e como as identidades culturais nacionais estão sendo afetadas ou deslocadas pelo processo de globalização. O crescimento da homogeneização cultural pode ter como consequência a desintegração das identidades nacionais e o surgimento de novas identidades.

O surgimento da Al Jazeera na pós-modernidade com uma postura pan-arabista deixa evidente esse deslocamento do sujeito.

Por estar perto dos acontecimentos do mundo árabe, a Al Jazeera tem adquirido substancial influência no mundo árabe, trazendo conflitos e questões para as salas de estar de uma audiência predominantemente árabe. De muitas formas, a Al Jazeera revigorou o senso comum no mundo árabe e encorajou uma unidade árabe, tanto que o pan-arabismo foi reinventado no canal (ZAYANI, 2005, p. 8).

Stuart Hall propõe, no entanto, que, ao invés de pensarmos no global como substituindo o local, seria mais interessante pensarmos em uma nova articulação entre o global e o local. Podemos enxergar os nacionalismos, tão presentes no receptor do canal, como uma expressão ambígua do desejo por assimilação no universal e por adesão ao particular.

O telespectador se vê na notícia veiculada. É sobre seu povo a informação ali presente, divulgada por jornalistas de mesma origem. 
Em vez de falar da identidade como uma coisa acabada, deveríamos falar de identificação e vê-la como um processo em andamento. A identidade surge não tanto da plenitude da identidade que já está dentro de nós como indivíduos mas de uma falta de inteireza que é "preenchida" a partir de nosso exterior, pelas formas através das quais nós imaginamos ser vistos por outros (HALL, 2006, p. 39).

Essa identificação é o que atraiu o apresentador Sami Zeidan, filho de mãe inglesa e pai saudita, para o canal árabe. Assim disse o apresentador de notícias Sami Zeidan:

Cada um vê o mundo com seus próprio olhos. E quando você tem uma organização de notícias feita por pessoas com os mesmos antecedentes culturais, eu acho que o produto natural disso é que eles vão ver o mundo de acordo com aquele contexto cultural. E o que é legal pra mim aqui na $\mathrm{Al}$ Jazeera é que isso representa uma diferença grande em termos culturais. E nós não vamos aceitar as normas, valores e estereótipos do ocidente. Nós vamos ver o mundo em uma perspectiva diferente (ZEIDAN, 2009).

Nos documentários e noticiários internacionais, o povo árabe sempre foi mostrado em grandes números, sem características pessoais ou individualidade. Edward Said reflete sobre essa relação entre ocidente e oriente que cria as imagens populares e representações negativas do árabe no resto do mundo:

O Orientalismo pode ser discutido e analisado como a instituição autorizada a lidar com o Oriente - fazendo e corroborando afirmações a seu respeito, descrevendo-o, ensinando-o, colonizando-o, governando-o: em suma, o Orientalismo como um estilo ocidental para dominar, reestruturar e ter autoridade sobre o Oriente (SAID, 2007, p. 29).

A partir do que se vê na televisão árabe Al Jazeera, desconstrói-se a idéia do estereótipo do sujeito árabe, postulado sobre a exterioridade. A figura do árabe, antes vista como a verdadeira imagem do oriente, não passa de representação. Segundo Said, todo o Orientalismo representa e se afasta do oriente - as referências feitas aos orientais antes da existência de uma rede árabe competitiva reafirmam essa tese.

Outra questão que devemos nos colocar para refletir sobre a Al Jazeera é o fato de ela estabelecer uma relação com o receptor através da televisão. Essa forma de comunicação, que combina imagem e palavra, cria um espelho que devolve ao público aquilo que é sua própria busca de descoberta do mundo. Mas, como o que está no conteúdo principal é a realidade, a televisão não pode apresentar-se como máquina de fabricar ficção, mesmo que, afinal, seja isso que ela produza.

A instância midiática televisual está numa posição de pivô duplamente orientada: referencial, quando olha para o mundo exterior que ela mostra, relata e comenta, e de contato, quando olha o telespectador que ela procura interessar e emocionar, que ela solicita e interpela. A televisão é, ao mesmo tempo, "instância exibidora" com relação ao mundo exterior e "instância 
exibida" com relação ao telespectador, sendo este "instância que olha". É a produção geral, lugar por excelência da articulação entre o mundo exterior, o estúdio e o telespectador, que coordena essa mise-en-scène (CHARAUDEAU, 2006, p. 89).

Assim, a televisão, fonte principal de informação de todo o Oriente Médio, se tornou também meio de identificação com a cultura árabe e com o islamismo. A Al Jazeera inovou ao trazer esse novo paradigma para a imprensa do mundo todo e ao fomentar a transformação de que carecia a região, não deixando dúvidas sobre sua importância no contexto local e internacional. 


\section{Capítulo 2 Cobertura de Guerras}

\subsection{1 - A primeira grande cobertura}

\subsubsection{Pós-11 de setembro}

Durante os meses seguintes aos atentados de 11 de setembro de 2011, nos Estados Unidos da América (EUA), o patriotismo consumiu o país. Uma nova legislação para controlar a mídia foi requerida e pela primeira vez o governo estava autorizado a investigar nome, endereço e correspondência - o que contribuiu para uma rigorosa autocensura na imprensa americana. A mídia se abstinha de publicar fotos da movimentação das tropas, em parte porque era negado o acesso à maior parte do que estava acontecendo.

Quando Osama Bin Laden se tornou o principal suspeito de cometer os ataques, ele já tinha aparecido na Al Jazeera mais de uma vez: em 1998, quando deu uma longa entrevista em que diz que os muçulmanos têm a obrigação de promover guerra religiosa; e em 2000, quando a emissora exibiu uma outra aparição no mesmo tom.

Nesse momento de tensão em toda a imprensa do mundo, a Al Jazeera recebeu uma correspondência com um discurso assinado por "Osama Bin Laden”, que dizia estar no Afeganistão e obedecer as regras do Talibã. Nove dias depois dos ataques em Nova Iorque e Washington, a emissora reprisou a entrevista exibida em 1998, em que Bin Laden fala sobre o dever de cada muçulmano de participar da luta contra Israel e EUA. Alguns dias depois, mais uma mensagem chega com a assinatura de Osama Bin Laden, em resposta ao que Bush chamou de cruzada. Começaram as especulações sobre a relação de Bin Laden com o canal.

A imprensa árabe em geral não publicou a foto ou a mensagem de Bin Laden, que já havia mandado vídeos para outras concorrentes e tinha sido ignorado. Governos árabes conservadores fizeram pressão para que houvesse controle sobre o que era divulgado e emissoras de todas as partes do mundo fizeram declarações indicando parceria entre a $\mathrm{Al}$ Jazeera e Bin Laden - que se pronunciou afirmando que assistia ao canal. Outras opiniões que se diziam ligadas a Al Qaeda e Talibã mandaram também seus recados e o Ocidente passou a ver o canal como a voz dos terroristas (MILES, 2005).

Mohammed el-Nawawy e Adel Iskander publicaram no livro The Story of the network that is rattling governments and redefinig modern journalism uma resposta aos críticos que sugeriram que a Al Jazeera era instrumento de propaganda de terroristas, dizendo que essas 
pessoas pouco conhecem a Al Jazeera e quase nada sobre sua incansável tentativa se cobrir cada ângulo de toda história publicada. E afirmam que a cobertura da Al Jazeera tem sido a mesma antes e depois dos ataques terroristas de 11 de setembro (El-Nawawy; Iskandar, 2003).

A Al Jazeera negou qualquer conexão especial com a Al-Qaeda e apontou que Bin Laden não escolheu o canal para fazer seus pronunciamentos porque tenha percebido lealdade com sua causa, mas pela credibilidade com a audiência. A imprensa ocidental, que condenava a relação, ainda se mostrava interessada em usar as imagens do canal. E no cenário internacional ela passava a ser conhecida como 'a CNN do mundo árabe'.

\subsubsection{O início da guerra no Afeganistão}

Desde que Bush declarou guerra, a imprensa do mundo todo aguardava a ida a Cabul para cobrir os iminentes ataques americanos ao Talibã. A imprensa local era controlada pelo Talibã, a televisão era banida desde 1998 como uma fonte de corrupção moral, a música era vista como suspeita, e liberdade de imprensa não existia havia anos.

Antes dos atentados, os únicos jornalistas na cidade eram afegãos trabalhando para agências de notícias internacionais. Depois, os acessos ficaram muito difíceis. Centenas foram ao Paquistão esperando conseguir dali um visto para o Afeganistão. Em outubro, cerca de 250 jornalistas, a maioria ocidental, já estava nas áreas de guerra.

A Al Jazeera tinha a única equipe de televisão no país, de modo que apenas a emissora estava apta a transmitir imagens. O governo americano passou a ter desentendimentos com a emissora árabe, mas não conseguiu segurar sua produção. Taysir Alluni era o correspondente em Cabul e Muhammad al-Burini em Kandahar, e o canal se gabava de ser o único na zona controlada pelo Talibã. A posição privilegiada permitia o monopólio das histórias e entrevistas, e as informações do Afeganistão eram diariamente devoradas pelos analistas que buscavam entender um pouco sobre aquele país quase desconhecido.

Eu entrei na Al Jazeera no primeiro dia de setembro de 2001, dez dias antes do evento que representou a grande mudança na história da Al Jazeera. Antes do 11 de setembro, a Al Jazeera era mais um canal falando para o mundo árabe. Depois a Al Jazeera se transformou imediatamente em um canal internacional. Tivemos aqueles exclusivos acessos no Afeganistão, éramos o único canal de outro lado do mundo no Afeganistão e isso nos deu fama, e isso continuou no Iraque e depois em outros conflitos (VAL, 2009). 
Quando os bombardeios começaram, os jornalistas se organizaram no norte do Afeganistão, controlado pelos inimigos do Talibã, a Aliança do Norte. Entrar nas áreas do norte controladas pelo Talibã significava cruzar uma linha de frente perigosa. Sem ter acesso ao que estava acontecendo no Afeganistão controlado pelo Talibã, a imprensa formou uma espécie de cercado onde compartilhavam as poucas informações que tinham e eram recompensados com notícias do Pentágono.

Mesmo sendo como as outras emissoras cobrindo a guerra, a Al Jazeera não fazia parte do grupo de imprensa e nem estabelecia relações com o Pentágono em troca de acessos. Era também a única emissora estrangeira na área controlada pelo Talibã e tinha o único meio de comunicação por satélite. Desde o 11 de setembro, eles entrevistavam autoridades do Talibã quase todos os dias, mas depois houve recusas e os acessos foram limitados. A busca pela notícia se tornou um desafio diário, mas ser um dos poucos ali tornava a Al Jazeera testemunha do que estava acontecendo e dona do monopólio da informação.

\subsubsection{Controle e censura}

A administração americana estava de olho na imprensa e advertiu os americanos que eles deveriam assistir às suas declarações sobre seu exército, serviço de inteligência e operações policiais. A Casa Branca pediu também que a mídia não divulgasse a agenda de Bush e Cheney, nem os nomes dos militares engajados nas missões.

Todos os chefes de emissoras concordaram com o pedido do Pentágono. O problema era que a mídia não iria parar de fazer questionamentos. O Pentágono tinha feito um trabalho de ensinar à imprensa americana como a cobertura deveria ser feita. As emissoras colaboravam em nome do patriotismo. A cobertura se tornou explicitamente tendenciosa a favor da Casa Branca e os jornalistas faziam questão de lembrar que os ataques eram apenas uma resposta ao que os EUA tinham sofrido em 11 de setembro.

Os passos tomados foram na medida de limitar a retransmissão de seu conteúdo nos Estados Unidos, ao pedir que os cinco maiores canais americanos censurassem vídeos da Al-Qaeda o que significava, na prática, evitar a Al Jazeera, já que era a única em condições de veicular isso, e não usar imagens do Bin Laden. Alegando que "a Al-Qaeda poderia estar comunicando mensagens escondidas para seus membros" ou que "a política era de evitar a transmissão de qualquer coisa que poderia facilitar uma ação terrorista", a imprensa americana acatou a decisão (MILES, 2005, p. 148). 
O pedido da Casa Branca para que os jornais não publicassem as mensagens de Bin Laden ou da Al-Qaeda foi apoiado pela Inglaterra. O mais leal aliado na "Guerra ao Terror" Tony Blair pediu à imprensa ser mais cética quanto aos discursos do Talibã e evitar dar voz aos extremistas islâmicos. As emissoras inglesas ficaram indiferentes e reivindicaram o direito de ser independentes como parte do processo democrático.

Desde que a Al Jazeera se tornou importante nesse período crítico, muitos outros canais do mundo passaram a retransmiti-la. E com as facilidades tecnológicas de internet e telefone, qualquer tentativa no século XXI de parar a comunicação da Al-Qaeda com o mundo estava destinada ao fracasso. Os apelos à censura não tinham limites para os ocidentais engajados na “Guerra ao Terror".

O Emir do Catar foi convidado para uma reunião com o presidente Bush e Colin Powell nos EUA por ser o presidente da Organização da Conferência Islâmica. Bush queria apoio na “Guerra ao Terror” e esperava mostrar que essa guerra não visava atingir os muçulmanos. Powell aproveitou a ocasião para falar sobre a Al Jazeera. As autoridades americanas estavam descontentes com as reprises da entrevista com Bin Laden e achavam que o canal estava dando espaço demais para análises hostis em relação aos EUA e encorajando o sentimento de antiamericanismo. O Emir foi à imprensa contar o que lhe foi pedido, negou que a cobertura da Al Jazeera seja parcial e recusou-se a interferir no jornalismo, segundo ele, feito com credibilidade e liberdade.

\subsubsection{O que foi e o que não foi noticiado}

Depois da primeira noite de bombardeios, o mundo aguardava as notícias até o Pentágono divulgar releases com imagens de coisas explodindo. Na manhã seguinte, Taysir Alluni mostrou a destruição dos ataques e como os afegãos estavam fazendo para reconstruir a vida. Na segunda noite, ele ficou no ar tentando adivinhar quantos eram os mísseis e quais os alvos, e novamente avaliou o estrago no dia seguinte. Com a morte de quatro funcionários das Nações Unidas, Alluni falou sobre o acontecido quando foi entrevistado ao vivo pela CNN. Também falou sobre a fuga de civis de Cabul.

A Al Jazeera foi reportando inúmeras histórias que representavam os ataques da coalizão. E, quando divulgou que um bombardeio americano matou centenas de médicos, enfermeiras e pacientes em uma hospital militar, o Pentágono negou. A Agence France Presse (AFT) também reportou. Quando a Al Jazeera contou a história de que o Talibã tinha derrubado um 
helicóptero americano, o Pentágono negou. Então o Talibã apresentou dois trens de pouso, exibindo na frente da câmera da Al Jazeera como se fosse um troféu de guerra. Donald Rumsfeld, o secretário da Defesa dos EUA, continuou classificando o apelo de "falso". Uma semana depois do início da guerra, o canal reportou que uma bomba americana atingiu um hospital em Kandahar, matando cinco pessoas. Inicialmente, o Pentágono negou e Rumsfeld chamou a cobertura de "ridícula", mas desta vez a emissora mostrou imagens de crianças afegãs queimadas, machucadas no bombardeio, internadas no hospital, chorando de dor (MILES, 2005).

Os repórteres da Al Jazeera tinham sempre fiscais do Talibã por perto e estavam constantemente sob pressão para aprovar o regime. No final de cada boletim, eles ressaltavam que estavam reportando do Emirado Islâmico do Afeganistão - o nome do Talibã para o país. Esse protocolo provocou muitas acusações de parcialidade. Por outro lado, dois correspondentes internacionais de Cabul, da AFP e da Reuters, publicaram relatórios condenatórios, reforçando as histórias da Al Jazeera sobre as causalidades civis afegãs. A AFP divulgou como os aviões americanos bombardearam civis afegãos tentando escapar para o Paquistão, matando ao menos vinte pessoas, entre elas, nove crianças. E as imagens da Al Jazeera dos vilarejos e hospitais bombardeados se destacavam na grande imprensa internacional e chamavam a atenção do mundo para a cobertura diferenciada do canal árabe.

\begin{abstract}
Nós mostramos civis sofrendo lá e também demos voz à Al Qaeda, porque para nós a Al Qaeda é uma parte do conflito. Damos o mesmo espaço e a mesma oportunidade para a Al Qaeda, e é por isso que fomos acusados de ser o canal do Bin Laden, mas isso porque é chocante para a audiência ocidental encontrar um canal que dê voz a pessoas consideradas inimigas. Damos a mesma oportunidade a George Bush e Osama Bin Laden, sem fazer distinção entre eles (VAL, 2009).
\end{abstract}

\title{
2.1.5 A emissora chamada de porta-voz do terrorismo
}

A Al Jazeera, que já tinha sido considerada pró-Iraque, sionista, agente dos americanos, agora estava sendo vista como porta-voz dos afegãos. E foram essas críticas à Al Jazeera que encorajavam sua notoriedade e chamavam a atenção para a contradição: o Talibã tolera o canal e os EUA, tão conhecido pela liberdade que a imprensa goza da interferência do governo, não. Diversos jornais do mundo árabe se pronunciaram criticando a tentativa de censura. A mensagem da Casa Branca não mudou a política editorial da emissora, mas gerou uma revolta no interesse do canal no Ocidente. 
Neste período, a Al Jazeera se tornou um nome familiar na América e ganhou fama rapidamente. Mas sempre que suas imagens eram aproveitadas por um canal americano, os apresentadores ressaltavam que o que estava sendo mostrado não podia ser confirmado, sempre sugerindo algum tipo de desconfiança. Na imprensa, era comparada à propaganda soviética ou aos jornais de propaganda nazista. Dizia-se que aquele era um jornalismo com inclinação antiamericana e anti-israelense ou que era um jornalismo profundamente irresponsável.

O New York Daily News publicou: "Nem mesmo uma organização de comunicação legitimada deveria ter monopólio de uma cobertura de guerra. Mas a Al Jazeera está longe de ter legitimidade. Isso é a propaganda árabe de um governo medieval...” (MILES, 2005, p. 149). E disse ainda que o papel do canal árabe era apresentar aquela matança como uma batalha injustificável, trazer a guerra às casas americanas como um show de horror.

Enquanto as redes de TV americanas se ocupavam difamando a Al Jazeera em público, por trás da cena os executivos das emissoras tentavam ser amigáveis ao canal a fim de poder usar suas imagens por um preço menor. E a emissora árabe continuava na tentativa de entrevistar o presidente dos EUA, apesar da resposta negativa da Casa Branca.

\subsubsection{O grande furo}

Pouco depois que a guerra aérea começou, a Al Jazeera parou sua programação para transmitir tudo ao vivo do Afeganistão. TaysirAlluni conduzia de seu "escritório" em Cabul a cobertura dos ataques. Durante a entrevista, um míssil foi lançado tão próximo da equipe do canal que tirou o cinegrafista de seu posto.

O apresentador Mhamed Krichen, um dos principais do canal desde 1996, estava no ar quando vivenciou um fato interessante. Em entrevista à pesquisadora, ele contou que durante as primeiras bombas, ouviu por meio do ponto uma voz confirmando que eles estavam ao vivo na CNN, BBC, Sky News... Naquele instante, uma significante parcela da população mundial viu a Al Jazeera pela primeira vez. As imagens de Alluni dos ataques em Cabul foram mostradas em emissoras de todos os lugares do planeta. Nessa primeira noite de bombardeios, Alluni anunciou que ele tinha acabado de receber um vídeo da Al-Qaeda que ele iria transmitir imediatamente, mesmo não sabendo o que continha. Era uma nova mensagem de Bin Laden, em seu primeiro pronunciamento oficial após o 11 de setembro. 
Mhamed Krichen (informação verbal) confirma que a decisão de exibir a entrevista aconteceu sem que nenhum deles tivesse conhecimento prévio do conteúdo daquela fita. Todas as emissoras estavam monitorando a Al Jazeera de perto - muitas retransmitiram em tempo real o que o canal árabe veiculava, interromperam a cobertura esportiva que acontecia ao vivo, outras, surpresas e inseguras da autenticidade do que iriam ver, organizaram-se para passar o discurso posteriormente. A administração americana ficou completamente sem armas para impedir as emissoras dos EUA de transmitir a mensagem, menos de três semanas depois de pedir que elas banissem os discursos de Bin Laden.

Neste vídeo, Bin Laden não reivindicou a responsabilidade pelos ataques, mas expressou apoio àqueles que os executaram. "A América foi abastecida de horror de norte a sul, de leste a oeste, e o que a América tem experimentado é só uma cópia do que nós experimentamos. Eu juro por Deus que a América não viverá em paz antes da paz reinar na Palestina”. Depois, seu chefe Ayman al-Zawahiri garantiu que os ataques foram induzidos pelo apoio americano a Israel. Pelas emissoras do mundo, algumas disseram que as imagens eram da Al Jazeera, outras mantiveram a política de não creditar. A entrevista foi repetida inúmeras vezes nos meses que se seguiram.

A pressão de veicular boas imagens quando todos dependiam dos resultados da Al Jazeera gerou barulho entre as emissoras por acordos de retransmissão. O mais importante furo da $\mathrm{Al}$ Jazeera até então fez com que o canal fosse visto com suspeita pelo ocidente. Foi sugerido ligação com o Talibã, foi sugerido que Bin Laden tivesse instruído o canal a veicular o vídeo no momento mais oportuno, possivelmente quando o bombardeio começasse. A explicação da emissora era a de que a última fita simplesmente tinha sido deixada na estação de notícias de Cabul, o que foi desacreditado.

Tony Blair, que tinha lido o Alcorão em um esforço de entender o Islã, fez um ataque contrário e pediu réplica. A emissora ligou e agendou uma entrevista para os próximos dias. Isso virou notícia. A Al Jazeera passou a receber telefonemas de todos os cantos e quando chegou no local combinado, a equipe foi alvo dos flashes dos fotógrafos - todos tinham se esquecido do Primeiro-Ministro. Blair escolheu mandar sua mensagem pela Al Jazeera pelo mesmo motivo que levou Bin Laden a fazer isso. Sua estratégia era atingir o maior número de pessoas possível e conquistar os corações daquela audiência (MILES, 2005). 


\subsubsection{O ataque ao escritório da Al Jazeera}

No começo de novembro, a Al Jazeera foi abordada pela administração americana, que tinha interceptado o recebimento de mais uma carta de Osama Bin Ladem. Havia um trabalho de grampo entre o escritório de Cabul e a sede em Doha.

Com medo do que poderia acontecer, a chefia em Doha ligou para Taysin Alluni em Cabul e disse que seria melhor ele sair da cidade logo. Alluni assegurou que tomaria o caminho da saída, mas mudou de ideia: por sua conta, fez contato com a Aliança do Norte e nem avisou Doha sobre a mudança de planos. Naquela madrugada, duas bombas americanas foram deixadas no escritório da Al Jazeera. Só uma explodiu, mas já foi suficiente para destruir o prédio, que estava vazio naquele horário.

A emissora ficou indignada com o ataque e o Pentágono negou que tivesse sido proposital. Era sabido que Alluni tinha sido ordenado a sair, mas não sabia que ele tinha ficado. Depois o Pentágono confirmou que o alvo do míssil tenha sido deliberado e garantiu que não tinha se arrependido porque o escritório era significante militarmente, como "uma facilidade usada pela Al Qaeda”. O monitoramento da Al Jazeera também foi confirmado.

Muitos americanos viram no ataque à Al Jazeera uma legítima extensão da Guerra ao Terror e acreditaram que a emissora deveria sim ser alvo porque era um braço da propaganda da máquina de guerra inimiga. Enquanto trabalhou de acordo com as regras do Talibã, Alluni manteve contato com o regime e fez algumas entrevistas com suas autoridades depois do 11 de setembro. Mas a emissora negou qualquer outro contato com a Al Qaeda.

\subsubsection{Al Jazeera em foco}

Pela primeira vez desde o lançamento da Al Jazeera, folhas e mais folhas foram dedicadas nos jornais e revistas ocidentais para analisar cada aspecto da emissora, desde seu efeito no processo de paz do Oriente Médio até detalhes pessoais de seu time. Por suas reportagens, a Al Jazeera se envolveu nos eventos como condutor e objeto da notícia.

A mesma emissora que criticou a Al Jazeera por ter um viés antiamericano estava satisfeita por transmitir com exclusividade suas imagens dos ataques em Cabul. A CNN exercitava seu acordo de exclusividade com a emissora árabe e acabou divulgando uma entrevista feita pelo repórter da Al Jazeera com Bin Laden antes mesmo da emissora árabe e sem o consentimento dela, o que causou discordância. A atitude parecia contraditória: depois de tanta crítica dos 
americanos à Al Jazeera por causa da exibição de vídeos de Bin Laden, a CNN exibiu em primeira mão a grande confirmação de seu envolvimento com os ataques (TV AL JAZEERA SATELLITE NETWORK, 2007).

A pergunta que fica é: por que a Al Jazeera não exibiu a entrevista antes da CNN? Foram inúmeras as vezes em que a $\mathrm{Al}$ Jazeera teve em mãos um material inédito relacionado a Osama Bin Laden - e muitos autores publicaram detalhadamente boa parte delas e dos fatos relacionados à emissora nesse conflito. A decisão de exibir ou de não exibir, nesse caso, a entrevista com Bin Laden, sempre foi muito questionada pela opinião pública, que dificilmente chegará a um consenso. O certo é que toda essa polêmica só contribuiu para fomentar as discussões sobre o canal e evidenciá-lo no cenário internacional.

Deliberadamente provocadora ou simplesmente controversa, a Al Jazeera parecia estar ganhando fama com o momento crítico. O subsídio do Emir de \$ 137 milhões era um montante que iria acabar em novembro de 2001, e o canal tinha que ser capaz de se sustentar se sua persistente reivindicação de ser independente do Emir fosse à prova d'água. Apesar dos gastos consideráveis da cobertura da guerra, a receita da assinatura e os honorários das imagens estavam aumentando. A Al Jazeera estava sendo intensamente demandada pelas emissoras do ocidente, todas queriam assinar acordos com o canal árabe (MILES, 2005, p. 150).

Segundo o autor, nas redondezas da Al Jazeera, em Doha, o humor estava esperançoso e os anúncios estavam crescendo. Mas a inteligência norte-americana continuava com os olhos atentos à emissora e à sua equipe e constantemente monitorando a comunicação entre Catar e Cabul. Os americanos estavam cada vez mais descontentes com o direcionamento adotado pela Al Jazeera e a vontade política de fazer alguma coisa começava a cristalizar-se.

O balanço final foi positivo para a emissora, que considerou que a guerra no Afeganistão havia consolidado a reputação da Al Jazeera como uma excelente emissora de TV. O risco de montar um escritório em um lugar atrasado tinha dado certo - manter presença no Afeganistão por dois anos deu à emissora o único acesso aos fatos. Com o intuito de conseguir outros furos, o canal abriu escritório em uma zona com potencial de notícias, entre Somália e Etiópia.

Muitas organizações de notícias louvaram a Al Jazeera pela cobertura da guerra. Entre as pessoas da imprensa ocidental, o canal foi considerado referência de factual. A fama também trouxe problemas: os correspondentes estavam em maior evidência e consequentemente eram mais atormentados. Muitos tiveram problemas em aeroportos e chegaram a ser impedidos de entrar em determinados países. Além disso, muitos países árabes continuavam negando autorização para que a Al Jazeera abrisse escritório. 
Durante a guerra, a audiência da Al Jazeera cresceu substancialmente e o rendimento de assinaturas e contratos também. Acordos para compartilhar informação e recursos estavam em andamento com CNN, ABC, NBC, Fox News e BBC, e outros países como Alemanha, Japão e China demonstraram interesse em retransmitir o conteúdo do canal árabe.

\section{$2.2 \quad 2003$ - A cobertura da invasão ao Iraque}

\subsubsection{Cenário que se repete}

A proximidade da guerra no Iraque faz lembrar muito a cobertura pós-11 de setembro. O que se via novamente em 2003 eram os acessos da mídia severamente controlados por um dos envolvidos no conflito e uma parcialidade significativamente evidente ao reportar fatos.

Podemos destacar o sistema a que a maior parte dos repórteres estrangeiros se submeteu para fazer a cobertura, aceitando comer, dormir e viajar com as tropas americanas para obter informações sobre parte da guerra desde que seguissem as regras impostas.

A coalizão, com o intuito de manter a mídia sob controle, organizava coletivas diariamente e mantinha um controle rigoroso sobre a informação ao levar jornalistas em suas operações. A vasta maioria deles era americana e cada um deles tinha um generoso apoio de imagens de ação.

Também podemos encontrar semelhanças com o que aconteceu no Afeganistão se olharmos para a preferência dos oficiais iraquianos por passar as informações aos jornalistas da $\mathrm{Al}$ Jazeera.

Além disso, havia uma desconfiança dos árabes que essa guerra tinha um teor religioso: uma cruzada cristã contra o universo muçulmano do país. A Al Jazeera dava oportunidade para os iraquianos falarem sobre esse desconforto, e a crítica mais uma vez classificava o canal como auto-falante do grupo que queria subverter o intuito da guerra.

Além dos problemas com a coalizão durante a guerra, o canal também teve problemas com o regime iraquiano. Nunca foi fácil fazer reportagens no Iraque: todas as emissoras eram obrigadas a ter um assessor do Ministério da Informação, responsável por ficar de olho nos jornalistas. Esse tipo de controle também esteve presente no Afeganistão.

Os meios de comunicação eram obrigados também a ficar nos dois maiores hotéis da cidade e a alugar escritório no Ministério da Informação iraquiano. Reportagens negativas sobre eventos no Iraque corriam o risco de provocar respostas punitivas, o que levou entrevistadores 
e entrevistados a evitar falar sobre os abusos de Saddam relacionados aos direitos humanos e a optar pela autocensura.

A manhã de 19 de março de 2003, no horário do Iraque, quando se ouviu os primeiros barulhos das bombas, começava também a tensão nas redações do mundo. E, mais uma vez, as emissoras americanas se alimentavam das imagens da Al Jazeera quase que imediatamente.

\subsubsection{Posicionamento diante da guerra}

Até o início da guerra, havia editorialmente no canal árabe um certo questionamento sobre a decisão americana de invadir o Iraque, de forma sutil, que deixava implícita a discordância da emissora em relação ao que estaria por vir. Depois que começaram os ataques, ficou claro que a Al Jazeera rejeitava a legitimidade da invasão.

Era através do texto e da terminologia adotada que se podia perceber a contestação em relação à estratégia da coalizão e seus motivos. Exemplos: era a única a adotar, no início do conflito, o termo 'forças de invasão', enquanto outros chamavam de 'forças de coalizão' e se referir a Saddam Hussein como 'presidente' e não como 'ditador'. E também desconsiderava a ideia de democratização ou de libertação como justificativa do conflito (MILES, 2005).

O que mais irritava os comandantes da coalizão sobre a Al Jazeera era o uso da palavra 'resistência' para descrever forças iraquianas. O canal não foi o único dos grandes a adotar este tipo de terminologia, mas foi o primeiro. Al-Arabiya, Abu Dhabi e outras logo começaram a evidenciar o mesmo tipo de ceticismo, de modo que, com o passar da guerra, a Al Jazeera parecia menos radical.

O porta-voz do Departamento de Estado Americano, Dr. Nabil Khouri, disse para os executivos da Al Jazeera que as reportagens da emissora não estavam só encorajando o uso de terminologia inapropriada, mas estavam glamourizando a posição iraquiana. Khouri também diz que nem todos que seguram em armas e atiram nas forças de coalizão no Iraque se qualificam como resistência.

Durante toda a guerra, a Al Jazeera terminava seus boletins com o âncora dizendo: "Nós deixamos você com imagens ao vivo de Bagdá". Na tela, a legenda "Bagdá está queimando" sobrepunha o que se via e a emissora deixava a interpretação daquelas imagens a critério do telespectador. Para os telespectadores árabes, a mensagem estava carregada de simbolismo. 
Uma das primeiras consequências da guerra foi uma onda de protestos por todo o Oriente Médio, tema de uma sólida cobertura da Al Jazeera.

Toda informação que o canal recebia, vinda do Comando Central da Coalizão ou do Ministério da Informação do Iraque, parecia ser tratada com igual ceticismo. Além de tentar ouvir os diversos lados do conflito, a Al Jazeera também buscava conteúdo com os mais variados comentaristas, com opiniões divergentes. Ahmad Chalabi, um dos mais importantes dissidentes iraquianos, também pôde expor suas ideias favoráveis à invasão.

Apesar das alegações de tendência para os dois lados, a Al Jazeera não favoreceu ninguém na guerra. Como a maioria dos árabes, se opôs ao regime de Saddam e se opôs à invasão. O canal se esforçou para mostrar que esta guerra não era simplesmente pela libertação da tirania, mas um complicado conflito que provocou diversas opiniões pelo mundo. E também tentou mostrar que a guerra tinha um custo humanitário, e as pessoas que mais sofreram no final eram civis iraquianos. A Al Jazeera nem exagerou o poder da resistência e nem minimizou a força da coalizão. Ao contrário do que o Departamento de Estado Americano alegou, a emissora reportou a resistência iraquiana somente onde ela existia e balanceou as reportagens com detalhes dos sucessos da coalizão (MILES, 2005, p. 274, tradução nossa).

\subsubsection{O que não se via}

A Al Jazeera tinha a única equipe de notícias em Basra, a segunda maior cidade do Iraque, que tinha ficado sem energia elétrica e sem água após a passagem das tropas. O canal estava transmitindo as urgentes necessidades de uma situação humanitária deteriorada. Por causa do que era exibido pela emissora, os comandantes da coalizão foram pressionados internacionalmente a fazer alguma coisa imediatamente para resolver a situação.

Surgiu então um misterioso rumor sobre um levante popular nas ruas de Basra. Dizia-se que os xiitas, oprimidos, estavam se revoltando contra o regime. Muitas redes de notícias americanas e britânicas tratavam os rumores sobre o levante xiita como se fosse um fato. A história teria se alastrado de outra forma se a Al Jazeera não estivesse lá para reportar a real situação. Quando o bombardeio parou, o correspondente do canal na cidade mostrou a calma nas ruas e nenhum sinal de rebelião.

A equipe visitou o Hospital Al-Jumhuriyah, onde civis iraquianos estavam feridos e morrendo. "É um enorme massacre de civis", disse uma mulher para a câmera. Desfazer falsos relatos da coalizão era uma consequência natural da política de ceticismo da Al Jazeera em relação a todas as partes, incluindo a coalizão (MILES, 2005). 


\subsubsection{O acesso à informação}

Muito comum nesse período foram as vezes em que o porta-voz da coalizão fazia coletivas a portas fechadas, sem que a equipe da Al Jazeera tivesse acesso. Se o número de jornalistas fosse limitado para visitar facilidades adicionais, as redes de notícias americanas invariavelmente eram escolhidas preferencialmente, em detrimento dos jornalistas árabes. Até porque a imprensa americana e britânica estava contente de embarcar na narrativa sobre a libertação do Iraque. Os canais de TV americanos eram particularmente patrióticos e claramente pró-guerra.

Alguns problemas com o espaço físico dos escritórios começaram a aparecer e, como consequência disso, credenciais foram rejeitadas para jornalistas do canal árabe. Algumas foram canceladas para repórteres que tinham a licença havia anos. A entidade responsável pelo credenciamento de imprensa inicialmente justificou a decisão como parte da iniciativa de aumentar o espaço no andar, mas depois colocou a segurança como razão, assim como a vontade de acomodar somente emissoras que fizessem uma cobertura responsável. Mesmo não citando o nome da Al Jazeera, o recado estava implícito.

Em contrapartida, os repórteres da Al Jazeera eram levados com frequência a ver hospitais lotados de civis, a pontes e rodovias bombardeadas, e quaisquer outras evidências de prejuízo colateral que o Ministério da Informação iraquiano pudesse apresentar. Isso gerou ainda mais desconfiança sobre o papel da Al Jazeera no conflito. Um movimento contra a emissora começou a surgir nos tablóides do mundo - o jornal americano New York Daily News publicou um artigo com acusações ao canal árabe de propaganda para Bin Laden, torcida para suicidas palestinos e ligação com o regime de Saddam (MILES, 2005)

O movimento contra a Al Jazeera foi visto como um ostensivo ataque à liberdade de expressão e gerou revolta em todo o mundo. O New York Times publicou um artigo em defesa do canal árabe dizendo que, "se a nossa esperança para o mundo árabe é, como a administração Bush nunca pára de nos lembrar, sua vida livre e democrática, Al Jazeera é o tipo de estação de TV que devemos encorajar" (MILES, 2005). 


\subsubsection{Imagens fortes nas telas da Al Jazeera}

A Al Jazeera quase diariamente mostrava crianças feridas, cadáveres e sangue. "Acredite em mim, tem muitas imagens que nós não mostramos", afirmou o apresentador Sami Zeidan.

Nós mostramos mais consequências da guerra para os civis do que talvez alguns canais internacionais de transmissão em inglês. E acho que isso acontece porque nós sentimos a responsabilidade de mostrar o máximo que pudermos da realidade contanto que seja apropriado para o espectador [...] E acho isso importante porque, por outro lado, quando você vai longe restringindo imagens, você pode ser acusado de sanitizar a guerra (ZEIDAN, 2009).

O Professor Dr. Mahmoud Hammoud questionou a cobertura da CNN durante a guerra no Iraque.

Quando alguns americanos foram mortos, eles não mostraram porque disseram que seus espectadores são muito sensíveis a ver sangue. Isso é um insulto ao povo árabe. Nós somos muito sensíveis a sangue também. Mas a verdade fica escondida quando há derramamento de sangue. É isso que está acontecendo. O Ministério de Defesa Americano proibiu qualquer veículo americano de mostrar funerais de soldados americanos no Iraque. E isso é porque americanos são mais sensíveis que os árabes em relação a funerais? Não é verdade. As pessoas são sensíveis. E essa é a verdade: o funeral de americanos mortos. E essa é a verdade sobre guerras: pessoas são mortas, civis ou militares. Mas claro que sabemos por que: porque eles não querem pessoas contra a guerra. Quando não se mostra, ninguém é influenciado. É só um número. Uma imagem é muito eficaz. Nós dizemos que uma imagem vale mais que mil palavras (HAMMOUD, 2009).

Uma das grandes polêmicas da cobertura da Al Jazeera no Iraque foi a exibição de imagens dos americanos e ingleses a serviço do Estado mortos no Iraque, alguns aparentemente executados com um tiro na testa. Depois de uma batalha em Nasariya, o canal árabe exibiu um vídeo de 30 segundos de iraquianos comemorando ao lado dos corpos de dois soldados britânicos mortos. O apresentador, em Doha, pediu desculpas pelas imagens horríveis, explicando que o objetivo de trazê-las era o interesse público.

O Ministério da Defesa britânico declarou que deplorava a decisão da Al Jazeera de exibir tal material. Donald Rumsfeld criticou a postura do canal e disse ser uma violação da Convenção de Genebra, que estipulava que prisioneiros de guerra deveriam ser preservados e não publicamente humilhados. O Departamento de Defesa Americano solicitou às organizações de notícias que não publicassem imagens ou áudio que identificasse os prisioneiros, para que familiares não ficassem sabendo pela TV da morte de um ente.

O porta-voz da Al Jazeera argumentou que mostrar as perdas da coalizão era parte importante da cobertura daquela guerra, que nada ia ao ar no canal se não tivesse importância jornalística. 
E que não mostrar essas imagens seria uma falhar no dever de mostrar a guerra da forma mais compreensível possível. Ele também apontou o fato de que, quando a Al Jazeera mostrava imagens de palestinos mortos, ou afegãos ou iraquianos, os Estados Unidos não tinham objeção alguma. E completou: "Nós não fizemos as imagens - as imagens estavam lá. É uma das faces da guerra. Nosso dever é mostrar a guerra por todos os ângulos" (MILES, 2005, p. 251).

$\mathrm{O}$ apresentador do canal árabe Mhamed Krichen (informação verbal) afirma que ninguém gosta de ver imagens de pessoas feridas, mas acha que quando se decide não mostrar, é uma forma de desinformar, esconder da população a verdade dos fatos. "Sangue é sangue. Guerra é guerra. É duro, mas é a realidade”, diz Krichen. Ele acredita que mostrar as atrocidades cometidas durante uma guerra é dever do jornalista.

\subsubsection{A morte e suas marcas}

O pior incidente até então aconteceu no dia 8 de abril, a poucos dias do fim da guerra. A equipe da Al Jazeera estava na cobertura do escritório no centro de Bagdá preparando uma transmissão ao vivo quando um tanque americano inesperadamente disparou dois mísseis naquela direção. O correspondente e produtor da emissora Tareq Ayyoub foi seriamente ferido e morreu pouco tempo depois. A nota divulgada pela empresa classificava sua morte como um fato trágico: “A Al Jazeera acredita que a real vítima é o jornalismo e a integridade profissional". E reiterou seu compromisso em continuar a buscar um jornalismo profissional, compreensível e balanceado (MILES, 2005, p. 265).

O escritório que os americanos atacaram era em uma zona residencial. Em 24 de fevereiro, o diretor da Al Jazeera havia escrito uma carta para a assistente da Secretaria de Defesa Americana para as Relações Públicas, em Washington, com as coordenadas exatas do escritório, avisando que ali jornalistas civis trabalhavam. Os mísseis atingiram exatamente as coordenadas passadas pela emissora para o Exército dos Estados Unidos.

Um outro correspondente da Al Jazeera em Bagdá disse, ao vivo: "Nós fomos atingidos porque os americanos não querem que o mundo veja os crimes que eles estão cometendo contra a população do Iraque". As reportagens no Ocidente sobre o ocorrido foram ofuscadas por outro ataque que matou dois jornalistas em um hotel, também classificado como acidente pelo Comando Central da Coalizão. 
O diretor da Al Jazeera mais uma vez escreveu para o governo americano perguntando por que o escritório fora atingido. Na resposta, nenhuma explicação sobre o ocorrido, apenas uma mensagem de condolências para a família de Ayyoub.

Nenhuma investigação sobre o incidente foi feita, de modo que ninguém foi responsabilizado pela morte de Tareq Ayyoub. Chegou-se a pensar dentro da Al Jazeera que o ataque ao escritório de Bagdá era parte de um esforço da coalizão de controlar a informação no campo de batalha. Depois do ocorrido, o diretor da emissora decidiu tirar seus repórteres do Iraque.

Mas a missão de reportar tinha que continuar e para isso a emissora sempre treinou profissionais para lidar com situações de conflito. O cinegrafista iraquiano Laith Mushtaq é experiente nisso. Ele fez parte do exército de seu país e foi enviado para a Guerra do Golfo em 1990 - levou um tiro na perna e saiu de lá entre os poucos sobreviventes. Depois se tornou jornalista, participou de inúmeras coberturas de guerra e vivenciou uma trágica situação enquanto trabalhava para a emissora árabe.

Em 2004, mais uma funcionário da Al Jazeera morreu na cobertura do conflito no Iraque. Rashid Hamid Wali estava na cidade de Karbala no dia 21 de maio quando foi atingido por um míssel. Ele era assistente de Mushtaq e estavam juntos no momento do acidente. "A primeira coisa que fiz foi segurar a câmera e gravar a cena". Apesar da terrível experiência, o cinegrafista acredita que todos devem que estar prontos para uma próxima batalha porque tem uma mensagem para passar (MUSHTAQ, 2009).

Essa não foi a única tragédia vivida por Mushtaq na guerra do Iraque. Uma bomba atingiu a casa da sua família e matou sua irmã. A revolta que nutre diante do fato e o ódio que sente pelos americanos é proporcional à devoção à cobertura da Al Jazeera. "A Al Jazeera não é um prédio, uma gerência, uma redação, paredes e mesas. Não, para nós, a Al Jazeera é um tipo de espírito". E, para comprovar a importância que a emissora tem em sua vida, pediu licença no fim da entrevista para um gesto e sigilo dentro do canal: certificou-se de que a câmera já tinha sido desligada, tirou o casaco, levantou a manga da camiseta e mostrou o logo da Al Jazeera tatuado na lateral do braço.

\subsubsection{A queda da estátua}

Quando a estátua de Saddam foi tombada, via-se ali o fim de uma história. Não da guerra, pois essa ainda estaria longe de terminar. Mas havia um clima de novos tempos na cobertura 
da Al Jazeera. O canal já tinha cumprido sua missão: era o mais popular entre os árabes e tinha crescido 10\% nessa guerra, chegando aos 50 milhões de telespectadores. Muitos desses novos vinham da Indonésia, o mais populoso país do mundo islâmico, onde o canal local começou a transmitir o sinal da Al Jazeera no início da guerra. Além disso, 4 milhões de europeus tinham assinado o canal, dobrando o número de espectadores europeus (MILES, 2005).

A ferramenta de busca Lycos divulgou que 'Al Jazeera' tinha se tornado o termo mais procurado, resultado da negação dos americanos em relação às imagens de soldados capturados e mortos. Enquanto as outras emissoras tiveram perdas de campanhas publicitárias, como Sky News e Fox, a Al Jazeera, que sempre recebeu muito pouco de anunciantes, estava numa situação melhor (MILES, 2005).

As maiores ocidentais usaram imagens do canal árabe durante a guerra, o que contribuiu para o saldo positivo. A emissora também avaliou os contatos no Iraque (e a presença de jornalistas iraquianos na redação que conheciam bem os lugares bombardeados) como um diferencial e a razão de a cobertura ter sido bem sucedida.

A revista Newsday publicou um artigo intitulado: "Quem cobriu melhor a guerra? Tente Al Jazeera", em que conta como o canal foi acusado de ser ferramenta de propaganda para os dois lados. Mas que os sucessivos ataques à emissora mostram que a maneira de cobrir a guerra - crítica e multidimensional, com compromisso ideológico com a democracia, abertura e pluralismo - tinha ameaçado os projetos políticos do mais poderoso do mundo (MILES, 2005).

Um levantamento feito pela Universidade de Sharjah mostrou a Al Jazeera como a que tinha mais credibilidade durante a guerra, seguida da Abu Dhabi TV, com Al-Arabiya em terceiro. No Afeganistão, a Al Jazeera ficou popular porque era a única emissora lá. A cobertura do conflito no Iraque alcançou fato inédito: a quebra a hegemonia das emissoras ocidentais pela primeira vez em centenas de anos, houve uma inversão do fluxo da informação, tradicionalmente feito do Ocidente para o Oriente (MILES, 2005). 


\subsection{9 - Intensivo sobre Gaza}

\subsubsection{4 horas de notícias}

Pela terceira vez em sua história, a Al Jazeera se dedicou integralmente ao grande factual do momento. Sua cobertura ficou focada no Oriente Médio: toda a programação habitual foi suspensa para dar lugar a 24 horas diárias de notícias sobre o conflito na Faixa de Gaza.

Com essa decisão, a cobertura da Al Jazeera se tornou mais aprofundada do que a de outras emissoras que continuaram divulgando notícias gerais, nacionais e internacionais. Não só pelas imagens que chegavam de Gaza a todo instante, mas pelas discussões que aconteciam nos estúdios em Doha, com profissionais de diferentes áreas, debatendo sobre diversas questões envolvendo a guerra.

O primeiro ataque aconteceu no dia 27 de dezembro de 2008 e seguiu-se até meados de janeiro. Com o fim da ofensiva, a Al Jazeera retomou a programação usual e voltou a dar espaço em seu noticiário para os acontecimentos pelo mundo. Foi quando Barack Obama assumiu a presidência dos Estados Unidos e o evento ganhou espaço na rede de televisão árabe.

Esse período da ofensiva na Faixa de Gaza também coincidiu com a pesquisa em questão, de modo que toda a cobertura da guerra pôde ser acompanhada de perto.

\subsubsection{Repórteres in loco}

A Al Jazeera era a única emissora presente na Faixa de Gaza quando os ataques começaram, o que lhe rendeu vantagem, uma vez que só conseguiu reportar de Gaza quem já estava lá antes de o conflito começar. Como a fronteira foi fechada, os jornalistas de outros veículos não tinham acesso à região e a emissora árabe pôde transmitir com exclusividade tudo o que acontecia ali.

O fato de termos correspondentes em Gaza faz a nossa cobertura muito diferente e distinta das outras porque os outros canais internacionais não têm correspondentes dentro de Gaza, então isso nos dá a competência de ter imagens que você não veria nos outros canais porque eles não estão lá, as consequências das bombas, o sofrimento dos civis, a situação nos hospitais, nas escolas atingidas, até nos mercados, como as pessoas compram comida? Essa vida em Gaza nós estamos aptos a mostrar (ZEIDAN, 2009).

O canal árabe sempre cobriu o conflito entre israelenses e palestinos em todas as áreas relevantes por anos e sempre teve bons acessos no lado palestino. Foi o que aconteceu nessa 
ofensiva. O canal tinha dois correspondentes lá quando começaram os ataques: AymanMohyeldin e SherineTadros. Havia também outros correspondentes nas fronteiras. Mohyeldin chegou à localidade em outubro, portanto quase três meses antes do início dos bombardeiros.

Em uma conversa por telefone, o repórter do canal baseado em Gaza Mohyeldin (informação verbal) falou sobre ser o único canal internacional dentro da Faixa de Gaza durante os ataques - apesar de haver outros jornalistas da imprensa local e poucos da imprensa européia e ocidental. Devido aos problemas de comunicação que afetavam os jornalistas - como dificuldades de acesso à internet e ligações telefônicas frequentemente interrompidas -, isso o impedia muitas vezes de entrar ao vivo quando necessário.

Ligação telefônica é um problema em Gaza normalmente, uma guerra em andamento não torna isso mais fácil, eles (os correspondentes) enfrentam, é claro, desafios pessoais, viver em uma cidade onde a infra-estrutura foi afetada não é fácil, pequenas coisas como disponibilidade de água, de eletricidade, que no inverno se faz ainda mais importante, fatos como esse dificultam as coisas para os civis, ainda mais pra quem também é jornalista e tem que trabalhar (ZEIDAN, 2009).

No dia da conversa telefônica, Mohyeldin disse que a situação ainda estava tensa, mas um pouco melhor que no dia anterior, mas que tinha medo, pois a segurança ainda era a principal questão para quem estava trabalhando na área. Jornalista experiente na cobertura de conflitos no Oriente Médio, Mohyeldin afirmou que esta era a pior guerra que já tinha vivenciado.

Ayman Mohyeldin e Sherine Tadros reportavam da porta de hospitais onde os feridos se concentraram e do topo de prédios enquanto caíam bombas ao redor. Ambos afirmaram que sentiram um enorme senso de responsabilidade de transmitir aqueles fatos, assim como tristeza pelos civis.

"O Ocidente e outros culparam o Hamas enquanto as pessoas aqui continuam sofrendo", disse Ayman. O comentário está carregado de indignação pelo fato de a mídia americana e ocidental nunca terem dado atenção suficiente às dificuldades do povo palestino (ZINGARELLI, 2010).

\subsubsection{Terminologia}

Enquanto alguns meios de comunicação se referiam ao conflito como "Guerra em Gaza", a Al Jazeera optou por falar em "Guerra a Gaza", tanto no canal em árabe quanto no canal em 
inglês. Essa escolha deu o tom de toda a cobertura ao assumir o discurso de que não havia uma disputa e sim uma guerra unilateral, sendo Gaza o alvo dos ataques israelenses.

Termos que descrevem topônimos e instituições militares, entre outros temas, também são motivo de divergência entre veículos distintos.

No caso da palavra terrorismo, nós ainda estamos aguardando das Nações Unidas a definição de terrorismo. Porque terrorismo na cabeça de um é diferente do que na cabeça de outro. A resistência à ocupação é chamada de terrorismo ou autodefesa ou o quê? Pergunte aos israelenses, eles vão dizer que sim, que é terrorismo. Pergunte aos palestinos, eles dirão, não, é resistência, é permitido na lei internacional resistir à ocupação (AZAR, 2009).

A Al Jazeera distingue-se das demais uma vez que adota palavras não usadas por outros canais, tentando assim evitar a compreensão inadequada dos conflitos.

Quando a Al Jazeera fala sobre a Cisjordânia, eles falam Cisjordânia ocupada, as Forças de Defesa Israelenses a Al Jazeera diria Exército israelense. O que os israelenses estão fazendo no sul do Líbano, em Gaza, na Cisjordânia, eles falam ocupação. Rótulos e descrições fazem muita diferença nas notícias. As pessoas são influenciadas por eles (HAMMOUD, 2009).

Observa-se que a terminologia muitas vezes está associada à compreensão de processos históricos diferentes ou posicionamentos.

Acredito que nosso principal desafio é discernir, jogar fora preconceitos que outros veículos acumularam por décadas sobre determinados assuntos. Como Gaza, por exemplo, na Palestina. Se você prestar atenção no que sai nos outros veículos, eles vão falar para você que todo o problema é sobre foguetes lançados pelo Hamas contra os israelenses, eles nunca vão além disso. Para nós o desafio é ser capaz de ir além disso, dar mais conhecimento, mais informação pra dizer às pessoas que não é sobre foguetes, é sobre mais de 60 anos de ocupação. Se você falar sobre como Israel foi criado, como os judeus migraram pelo mundo, elas não gostam de ouvir porque não estão acostumadas a ouvir (VAL, 2009).

\subsubsection{A cobertura}

A Al Jazeera cobriu a guerra como um sofrimento humanitário histórico. A cobertura criticou as atitudes israelenses, e os repórteres em Gaza falaram do sofrimento das famílias, mostraram sangue e até crianças mortas deitadas em camas de hospital. Foi uma cobertura pesada, que se dedicou às consequências da guerra, tanto físicas quanto psicológicas. A Al Jazeera mostrou o ponto de vista dos israelenses, mas o Exército e o governo israelense apareceram como vilões atacando civis inocentes (ZINGARELLI, 2010, p. 81).

Em sua dissertação de mestrado "The CNN effect and the Al Jazeera effect in global politics and society", Zingarelli mostrou de que forma a cobertura da Al Jazeera e da CNN 
influenciou políticas globais e a sociedade. Ela também comparou as duas emissoras em diversos momentos importantes da história, como o conflito em Gaza, e entrevistou Willian A. Rugh, diplomata americano e professor universitário especialista em Oriente Médio. Rugh afirmou que os árabes olham para a cobertura da imprensa americana como sendo tendenciosa contra os árabes e assim inútil porque não apresenta um retrato balanceado de Gaza. E eles acham que, se tivesse, haveria uma política mais balanceada (ZINGARELLI, 2010).

A cobertura da CNN durante a ofensiva foi muito diferente da emissora árabe: bem mais distante do que de fato estava acontecendo. Talvez por isso, tantos americanos sintonizaram na Al Jazeera para ter notícias do conflito. Segundo a emissora, as visitas ao site aumentaram $600 \%$ durante a guerra a Gaza, e $60 \%$ do aumento vieram dos Estados Unidos (ZINGARELLI, 2010).

A internet como um todo se tornou ferramenta importante nesse período. Basta a pessoa ter conexão para se tornar participante do conflito, acessando as fotos de Gaza, vendo vídeos no Youtube, postando comentários no Twitter. Por meio desta guerra, a mídia teve o papel de mobilizar mais pessoas para ter sua voz sobre a guerra. A imprensa é símbolo de poder como as armas, e essa nova imprensa está criando novos meios de abranger diversas culturas na guerra ou na paz. A Al Jazeera estava usando essas plataformas para influenciar a opinião da audiência e reverter o fluxo de informação.

\section{$2.4 \quad 2011$ - O ano da Primavera Árabe}

\subsubsection{O início da cobertura da Al Jazeera}

Quando os primeiros protestos de 2011 começaram a surgir no mundo árabe, ninguém imaginava o que ainda estaria por vir. Até então, havia uma apatia diante da sucessão dos governos planejada para os filhos dos ditadores e uma população sem esperança de mudança aguardando uma solução divina. A juventude, nas redes sociais, era quem ainda manifestava alguma força, mas os governantes achavam que poderiam calar os jovens conectados com o mundo.

Nós, da mídia, fomos pegos de surpresa no começo. Nossa cobertura da Tunísia, nos dois ou três primeiros dias, foi muito leve. Nós não esperávamos aquelas coisas, pessoas sempre protestam, mas que aqueles protestos poderiam virar revolução isso não era parte da nossa expectativa (KHANFAR, 2012, p. 7) 
Assim disse o então diretor geral da Al Jazeera Wadah Khanfar, em entrevista à pesquisadora Jane Kinninmont, da Chatham House.

O pesquisador Parag Khanna escreveu uma obra que trata das relações na ordem mundial em que apresenta uma visão diferente sobre a conjuntura política no Oriente Médio poucos anos antes do início da Primavera Árabe. Nela ele afirma que alguns observadores ocidentais fazem questão de apresentar as sociedades árabes como atrasadas ou medíocres. Mas nesse caso é o Ocidente que é incapaz de lidar de maneira produtiva com uma cultura árabe supostamente simplista.

Enquanto o Ocidente se queixa da desordem árabe, vai surgindo uma ordem árabe que define o futuro da região. A combinação de uma enorme riqueza petrolífera, da influência dos meios de comunicação de massa, das queixas compartilhadas na região e da dolorosa consciência do caráter arbitrário das fronteiras impostas pelo Ocidente está transformando a paisagem política árabe, onde surge uma opinião pública extraordinariamente consolidada, que desconfia da política externa americana e contesta a legitimidade dos governantes não eleitos (KHANNA, 2008, p. 329).

Nesse trecho, pudemos observar que já havia uma constatação da mudança de pensamento da sociedade árabe. Enquanto muitos não acreditavam no conhecimento adquirido nos últimos anos nos países árabes, os habitantes da região já mostravam a postura contestadora que marcou as revoltas do ano de 2011. E Khanna antecipa o que estaria por vir:

A geração dos árabes mais jovens dissemina esses sentimentos por meio do intercâmbio estudantil, das reuniões de militância e dos blogs na Internet. Essa ampla e coordenada pressão de baixo para cima em prol da mudança política é uma tendência que não se encontra com consistência equivalente em qualquer outra parte (KHANNA, 2008, p. 330).

Paulo Farah também analisa os impactos da globalização no mundo árabe. A partir do contato com os recursos que essa nova realidade oferece, os muçulmanos tentam adaptar-se às informações.

A Internet desperta, em alguns governos, o temor de que seus usuários questionem mais intensamente a legitimidade dos regimes que os dirigem, muitas vezes, sem aprovação popular. Ao mesmo tempo em que Estados de maioria islâmica tentam modernizar-se, intensifica-se a preocupação em preservar a cultura local e revitalizar as tradições (FARAH, 2001, p. 85).

O fato é que as redes sociais tiveram um papel importante no começo. Porque em ambos em os países, Tunísia e Egito, e depois obviamente na Líbia, a Al Jazeera não tinha correspondente cobrindo os eventos. Na Tunísia não havia ninguém porque a Al Jazeera foi banida. No Egito, imediatamente após o início da revolução, a Al Jazeera foi banida, o 
escritório foi fechado e os correspondentes não estavam autorizados a circular pelo país. E até o sinal de satélite da Al Jazeera no Egito foi derrubado.

Pela visão de Khanfar, foram as imagens postadas nas redes sociais que alimentaram o canal de notícias sobre a revolta no Egito, o que deu ainda mais credibilidade à emissora. Os vídeos, sem alta definição, sem estabilidade e de qualidade ruim foram bem aceitos pelo público, que via mais autenticidade naquele tipo de registro do que de profissionais qualificados.

Quando o presidente egípcio Hosni Mubarak cortou a internet e os sinais de telefone, em 27 de janeiro de 2011, as informações da Al Jazeera abasteceram o mundo. Foi uma grande vitória do canal, pois muitas organizações ocidentais, que tinham dificuldade de colocar repórteres no Egito e não conseguiam se comunicar com quem estava no local, foram obrigadas a retransmitir as imagens da Al Jazeera.

\begin{abstract}
A Al Jazeera pede que as massas árabes expressem nossas vozes. E isso é o que nos faz sentir poderosos daquilo que estamos fazendo. $\mathrm{E}$ isso é o que tem deixado muitos governos furiosos conosco, porque de alguma forma nós estamos fazendo algo que eles não querem ver acontecendo: árabes expressando suas vozes e sendo capazes de criticar e talvez de encarar os déspotas que se impõem por meio de seus regimes (VAL, 2009).
\end{abstract}

\title{
2.4.2 "Notícias reais"
}

A Secretária de Estado dos Estados Unidos Hillary Clinton, em março de 2011, elogiou a cobertura da emissora árabe. "Você pode não concordar com a Al Jazeera, mas sente como se estivesse obtendo notícias reais 24 horas por dia ao invés de um milhão de comerciais e argumentos entre especialistas e essas coisas que a gente faz no nosso noticiário, que não é particularmente informativo para nós". Ela afirmou também que a Al Jazeera tem sido líder em mudar as ideias das pessoas e as atitudes e conclui que é uma emissora que precisa ser assistida, pois faz um jornalismo real (ABC NEWS, 2011).

\subsubsection{Na visão dos críticos}

O periódico Jadaliyya publicou um artigo de Vivian Salama mostrando que foi nesse período da Primavera Árabe que algumas feridas da Al Jazeera começaram a aparecer. A renomada rede de televisão que colocou o Catar no mapa começou a enfrentar um dilema. Segundo Salama, a emissora teve dificuldade de se distanciar dos interesses políticos de seus donos - 
os governantes do país - que mantinham o canal vivo em função dos 100 milhões de dólares que depositavam ali a cada ano. Além disso, a onda de informação agora disponível na internet expôs os buracos da cobertura que não estavam alinhados aos interesses dos governantes e destacou os vieses nas várias revoltas (SALAMA, 2012).

Também foi significativa a cobertura dos acontecimentos no Bahrein, em março de 2011. Os protestos foram pouco noticiados e muitos atribuíram isso à relação do Bahrein com o Catar ambos são membros do Conselho de Cooperação do Golfo. A Al Jazeera produziu um documentário premiado sobre a situação do Bahrein, que foi exibido apenas uma vez no canal em inglês e nenhuma no canal árabe.

Um dos grandes alvos de críticas durante a Primavera Árabe foi a cobertura da Al Jazeera das revoltas na Líbia - considerada reflexo da posição do governo do Catar em relação ao regime de Muammar Khadafi. A emissora optou por usar a bandeira tricolor dos rebeldes ao invés da bandeira verde do regime de Khadafi. E deixou de noticiar os abusos cometidos pelos rebeldes. $\mathrm{O}$ mesmo tipo de questionamento se deu em relação às revoltas na Síria. A cobertura foi considerada por muitos parcial, contra o regime de Bashar al-Assad.

Em janeiro de 2012, no editorial do jornal saudita Arab News, Ramy Baroud escreveu:

A Al Jazeera começou a mudar o curso. Ela desviou-se de suas responsabilidades na Líbia e está agora completamente perdendo o rumo com a Síria. Sim, talvez o regime sírio deva ser trocado, e talvez uma rebelião armada na Síria irá eventualmente substituir a revolta não violenta. Mas a decisão desse desfecho não cabe a mim, à Al Jazeera, ao The New York Times ou a nenhum outro jornalista ou veículo (SALAMA, 2012, p. 6)

\subsubsection{Demissão em massa}

O Catar recentemente se uniu com outros regimes árabes do Golfo para oferecer assistência aos oposicionistas da Síria por meio de fornecimento de salário e armas. Um grupo de funcionários da Al Jazeera no escritório de Beirute, incluindo o correspondente Ali Hashem, que cobriu tanto as revoltas na Síria e na Líbia, pediu demissão em março (de 2012), destacando o viés da emissora. Em uma entrevista, Hashem citou uma mudança na política de cobertura dos eventos na Síria e disse que tinha se tornado demasiadamente difícil manter esse viés e ignorar outros importantes ângulos da história (SALAMA, 2012).

O problema continuou para a emissora do Catar quando, em setembro, o site da WikiLeaks, organização não-governamental que publica informações secretas, referiu-se à Al Jazeera como "uma das mais valiosas ferramentas de política e diplomacia". As correspondências 
divulgadas do Embaixador americano em Doha mostram que o diretor-geral da Al Jazeera Wadah Khanfar estava disposto a remover do site da Al Jazeera alguns termos que incomodavam o governo americano. Menos de um mês depois, Khanfar também desligou-se da empresa.

Logo após o anúncio da saída de Khanfar, ele falou ao canal em inglês da Al Jazeera sobre os motivos que levaram à sua saída. $\mathrm{O}$ escândalo envolvendo o WikiLeaks foi mencionado, e Khanfar admitiu que sempre sofreu pressão por parte de diversos governos, mas que isso não tinha a ver com sua decisão. Quem assumiu o cargo de diretor-geral foi Sheikh Ahmad Bin Jassim bin Mohammad Al Thani, membro da família real. Nessa mesma entrevista, Khanfar enfatizou que a Al Jazeera é uma emissora independente do governo e que continuará seguindo essa política na nova gestão (TV AL JAZEERA, 2011). 


\section{Capítulo 3 A consolidação da Al Jazeera e o surgimento de outros canais no mercado}

\subsection{Comemoração dos 10 anos de Al Jazeera}

Quando a Al Jazeera completou 10 anos, em 2006, foram inúmeras as comemorações da emissora celebrando o aniversário. "Atingir o topo é, como dizem, difícil. Mas continuar lá é ainda mais complicado. Al Jazeera, que, desde o primeiro dia ficou no topo, tem administrado manter sua excelência por meio da multiplicação de esforços e de habilidades apresentadas", disse o ex-diretor do canal Mohamed Jasim Al Ali (TV AL JAZEERA SATELLITE NETWORK, 2007, p. 24).

A Al Jazeera é um novo fenômeno que começou 10, 15 anos atrás e desde então se tornou um fenômeno mundial porque a imprensa era controlada por pontos de vista ocidentais. A maioria das agências de notícias, das emissoras de televisão, a maioria dos jornais são orientados pelo Ocidente - $\mathrm{CNN}$, revista Time, Newsweek, Reuters, tudo o que é considerado uma visão de mundo sob perspectiva do norte. Assim não há pontos de vista oriundos do sul ou de países de Terceiro Mundo. Al Jazeera quebrou o monopólio das notícias (HAMMOUD, 2009).

Mas o que a Al Jazeera conquistou nessa primeira década de existência vai muito além dessas comemorações de aniversário de apenas um canal de televisão. Philip Seib publicou em 2008 uma análise sobre como as novas mídias mudaram o cenário internacional (SEIB, 2008). Em sua obra, a Al Jazeera é colocada como símbolo de uma nova mídia, que afeta políticas globais e a cultura ao valorizar a influência do mundo islâmico. Ele afirma que o crescimento da nova mídia tem sido explosivo.

A Al Jazeera era, no final da década de 90, uma pequena estação de notícias. Hoje são mais de 450 canais de satélite árabes no ar - a maior parte privados - trazendo o fím da dominância estatal na imprensa na região. E as novas redes de comunicação estão levando embora a influência da $\mathrm{CNN}, \mathrm{BBC}$, e outras organizações ocidentais em que boa parte do mundo confiou por tantos anos (SEIB, 2008).

Seib relembra o "efeito CNN" - teoria em que a cobertura de notícias de eventos internacionais estava influenciando a atitude de governos pelo mundo - para refletir sobre o “efeito Al Jazeera", termo usado para generalizar essa nova mídia que surge dando voz a grupos marginalizados (SEIB, 2008).

Para ele, o uso de novas mídias como ferramenta em todos os aspectos das relações internacionais dá um passo a mais. No passado, os governos podiam controlar muito do fluxo 
de informação e assim dominar as mudanças políticas. Hoje o governo pode prender alguns blogueiros ou derrubar algum sinal de satélite, mas a inundação de informação já está estabelecida (SEIB, 2008).

A mídia não é mais apenas a mídia. Eles têm uma ampla base popular maior do que nunca e, como resultado, um impacto sem precedente na política internacional. A mídia pode ser ferramenta de conflito ou instrumento de paz; pode tornar irrelevantes fronteiras tradicionais e unificar pessoas espalhadas pelo mundo. Esse fenômeno - o efeito Al Jazeera - está redefinindo o mundo (SEIB, 2008, p. XII).

A Al Jazeera e os outros meios de comunicação contribuíram de forma significativa na formação do senso crítico na sociedade árabe e ajudaram a despertar o desejo de mudança.

Nos países árabes onde a vida pública foi por décadas dominada pela voz do estado, a Al Jazeera antecipou um novo tipo de política pública aberta e controversa, na qual excessivas vozes clamavam por atenção. Ao invés de impor uma única e esmagadora opinião, a nova estação de TV, junto com jornais, sites e outros meios de comunicação, desafiou os árabes a argumentar, a discordar e a questionar o status quo. Esses argumentos públicos, enérgicos em sua invocação de uma identidade árabe aflita, algumas vezes demasiadamente conformistas e outras vezes amargamente analíticos, sensacionalista mas libertadora, definiram um novo tipo de público árabe e uma nova forma de política árabe (LYNCH, 2007, p.2).

\subsection{Surgimento do canal em inglês}

A própria Al Jazeera reconheceu que, se fosse para expandir para o mundo sua influência, não poderia fazer isso inteiramente em árabe. Em 2006, depois de muito tempo de preparação, lançou um canal em inglês. O fato era histórico: pela primeira vez, um canal de notícias sediado no Oriente Médio se fazia em inglês. Com os principais centros de transmissão em Doha, Washington, Londres e Kuala-Lampur, deparou-se com o desafio de provar que podia ir ainda mais além (TV AL JAZEERA SATELLITE NETWORK, 2007).

A criação do canal em inglês era mais um passo para consolidar a nova ideologia do Catar. Como o alcance é bem maior, árabes e não árabes do mundo todo podem assistir ao canal, já que é em inglês. O conteúdo, de certa forma vinculado ao conteúdo do canal árabe, chega aos espectadores na Europa, nos Estados Unidos e onde mais houver descendentes de árabes que não herdaram o conhecimento da língua.

Nazar Dow, funcionário dos dois canais, é editor de um programa exibido nas duas línguas, com sua adaptações. Para ele, a grande diferença entre a Al Jazeera em árabe e em inglês é que são destinadas para espectadores diferentes, com expectativas diferentes, o que afeta tudo o que é feito nos dois canais (DOW, 2009). 
O novo Emir reforçou as transformações que fez no país com o canal em inglês, uma vez que a abrangência passou a ser ilimitada Além disso, trouxe jornalistas de todo o mundo para trabalhar no canal (funcionários de dezenas de nacionalidades), buscando, cada vez mais, dar condições para que eles se sentissem confortáveis em trabalhar ali, como se estivessem em seu próprio país.

Nós temos pessoas de aproximadamente 60 nacionalidades. Elas são diferentes, muito diferentes. A totalidade de pessoas faz a cultura, gera o que seria chamado no futuro de cultura da Al Jazeera em inglês. Está em processo de amadurecimento. Não está completamente pronto, mas está em andamento. Eu vejo o desenvolvimento e aprecio ser parte disso (DOW, 2009).

Philip Seib analisa o início da transmissão do novo canal de notícias:

Durante os primeiros meses, a Al Jazeera em inglês pareceu estar bem em seu modo de definir seu espaço no mercado. A extensão de sua cobertura, particularmente sua ênfase em reportar do sul ao norte, a distinguiu de muitos dos seus competidores. A completa cobertura no Oriente Médio e na África proporciona a perspectiva que os outros canais via satélite não tinham mostrado (SEIB, 2008, p. 42).

Mas não foi tão fácil assim conquistar o público. Grandes nomes do jornalismo internacional foram contratados para atrair credibilidade - a emissora ainda era conhecida popularmente como "o canal de Osama Bin Laden”.

Enquanto a Al Jazeera em árabe tem a vantagem de reconhecimento entre seus espectadores, o canal em inglês levou muitos anos para ganhar notoriedade, particularmente porque ela focava em uma audiência diferente da do canal em árabe (SALAMA, 2012, p. 3).

E os questionamentos vieram: o novo canal é a versão do canal árabe em inglês ou há diferença editorial entre eles? O novo canal mantém a proposta inicial de falar para o público árabe - nesse caso, descendentes e simpatizantes da cultura que não aprenderam a língua? Ou busca também atrair quem não tem nenhum vínculo com esse universo e quer apenas um noticiário de qualidade? O canal em inglês pode ser considerado uma versão júnior da $\mathrm{CNN}$ ou BBC? Ou é apenas o cenário moderno que se parece com as emissoras ocidentais?

Sami Zaidan, o primeiro apresentador do canal em inglês, se considera o rosto e a voz que lançaram as primeiras palavras na nova Al Jazeera. Para ele, o estilo de produção não é como a Al Jazeera em árabe, está mais perto das emissoras ocidentais, mas o conteúdo mantém a mesma linha editorial, apesar de terem interesses diferentes (ZEIDAN, 2009).

O estilo de produção de TV é muito diferente do canal em árabe, em termos de tipo de história que cobrimos nosso foco é mais global enquanto a $\mathrm{Al}$ Jazera em árabe é mais regional, mas acho que o espírito é o mesmo entre a Al Jazeera árabe e a Al Jazeera inglês, e acho que são muito diferentes da 
BBC e CNN [..] Nós estamos olhando as coisas não da perspectiva de um olhar ocidental e não da perspectiva de uma cultura ocidental, nós estamos olhando as coisas de perspectiva da voz do sul, que nem sempre é escutada (ZEIDAN, 2009).

O fato é que não há um consenso sobre a identidade do novo canal. Se nem todos os jornalistas que trabalham lá sabem responder a essas perguntas, quem vê de fora fica ainda mais confuso - principalmente se não tem o domínio do idioma árabe para poder comparar. Além disso, esse é um capítulo bastante recente da história da Al Jazeera, portanto, ainda pouco explorado, e merece um estudo posterior mais aprofundado.

\subsubsection{Difusão}

Seib também explica que inicialmente o canal em inglês estava disponível para 80 milhões de lares por satélite e TV a cabo. Mas acessível para apenas um pequeno número de espectadores nos Estados Unidos (principalmente por meio dos provedores via internet) por causa de razões políticas. Porque a Al Jazeera já tinha sido completamente demonizada pelo governo norte-americano - chamada de "o canal de Osama Bin Laden" -, o principal serviço de sinal de satélite TV a cabo se recusou a transmiti-lo (SEIB, 2008).

A Al Jazeera e outros canais internacionais tiveram que driblar alguns obstáculos políticos e técnicos ao transmitir sua produção televisiva via internet. Ao mesmo tempo em que isso representava um avanço uma vez que a compra de um pacote de um provedor dava acesso a todo o conteúdo do canal, não se pode dizer que o problema estava resolvido, pois a relação entre o telespectador de um canal de TV não é a mesma que a de um internauta com um site de notícias. É necessário estar conectado para assistir à programação, é necessário escolher o vídeo, é necessário clicar e tudo isso dificulta o acesso, ao passo que basta o televisor estar ligado para o sujeito receber o que a emissora escolhe transmitir naquele horário.

O problema ainda existe nos Estados Unidos e em outros países como o Brasil, onde é difícil conseguir instalar o equipamento apropriado para receber o sinal da Al Jazeera, mesmo que se tenha TV por assinatura. Assim, muita gente que já ouviu falar sobre a famosa emissora árabe muitas vezes não tem oportunidade de conhecer melhor o jornalismo feito em Doha porque não tem acesso ao canal. 


\subsubsection{Expansão}

Quando começou, a Al Jazeera ficava no ar durante seis horas. A transmissão 24 horas por dia começou em fevereiro de 1999, de três diferentes satélites: Oriente Médio, América do Norte e Europa. De 150 funcionários, passou para 500, e nesse período contava com 12 escritórios a maioria no mundo árabe, mas também na Europa e Rússia. No mesmo ano, abriu escritório em Teerã e no Afeganistão, a convite do Talebã. Os palestinos também escolheram a Al Jazeera para ser sua primeira fonte de notícias (TV AL JAZEERA SATELLITE NETWORK, 2007).

A internet também impulsionou o crescimento do canal. O site aljazeera.net foi lançado pouco antes do 11 de setembro e ganhou grande destaque e notoriedade nesse período. Assim diz Gloria Awad em um ensaio sobre o tema:

Aljazeera.net recebeu 161 milhões de visitantes no ano de 2002, principalmente de usuários do Oriente Médio (54\%), seguidos pela Europa e Estados Unidos (39\%). O site entrou no ranking dos cinco mais visitados. A procura por informações sobre o Oriente Médio nesse contexto de guerra não é surpresa (ZAYANI, 2005, p. 81).

Durante o início da guerra do Iraque, em 2003, a versão em inglês do site da Al Jazeera foi lançada. Editado por um antigo jornalista da BBC, o site restringia o conteúdo aos acontecimentos do conflito, oferecendo a contagem de bombardeios da coalizão assim como fotos e posteriormente as controversas imagens de soldados mortos.

A Al Jazeera também lançou no mesmo ano um canal só de esportes e ainda passou a oferecer também mensagens de texto com atualizações de notícias, em inglês e árabe, para celulares de 130 países. No ano seguinte, criou o Centro de Treinamento e Desenvolvimento da Rede Al Jazeera. Em 2005, lançou um canal que fica 24 horas por dia ao vivo e um canal infantil.

Outro grande passo para o crescimento Em 2007, foi lançado um canal de documentários. Assim, os assuntos que merecem mais tempo não precisam se restringir a uma reportagem dentro de um jornal diário. Eles viram documentário de, em média, uma hora, em que é possível elaborar ainda mais diversos aspectos de um tema. E o que era apenas um canal de notícias no início se multiplicou. Hoje há canais em árabe e em inglês, de esporte, infantil, de documentário e uma estrutura enorme que também envolve as páginas na internet e um centro de estudos e treinamento (TV AL JAZEERA SATELLITE NETWORK, 2007). 


\subsection{Repercussão: similares pelo mundo}

O sucesso do canal estimulou um crescente número de clones pela região e a dominância que a Al Jazeera aproveitou durantes os primeiros anos estava diminuindo. Entre as concorrentes que apareceram depois da fama da Al Jazeera destaca-se a Al Arabiya.

Desde que a Al Jazeera foi lançada, desde que a Al Jazeera se tornou um modelo desse tipo de progresso no mundo árabe, de liberdade de expressão, muitos canais têm tentado competir com a Al Jazeera, imitá-la, como a Al Arabiya, por exemplo, em Dubai, como muitos outros canais, El Ekhbariya, na Arábia Saudita, quase todo país tentou fundar um canal que pudesse competir com a Al Jazeera ou, ao menos, que pudesse imitá-la (VAL, 2009).

A Al Arabiya foi lançada em 2003 pela Middle East Broadcasting Center (MBC), - um centro de transmissão do Oriente Médio, que é de donos sauditas e baseado em Dubai. Segundo o grupo, "o canal foi criado como resposta à necessidade da audiência árabe de uma fonte de notícias verdadeiramente relevante, balanceada e responsável” (SEIB, 2008).

O formato da Al Arabiya é basicamente o mesmo da Al Jazeera: noticiário intercalado de programas de debate. Os diretores da emissora reconhecem o potencial que têm os canais de notícias. Abdul Rahman al-Rasehd, diretor-geral, disse que a Al Jazeera e a Al Arabiya "são mais perigosas que bombas nucleares e que irradiam em larga escala". Suas notícias, acrescentou, poderiam empurrar os telespectadores "a ir à guerra, ou poderiam fazer as pessoas acreditar na paz e mudar suas vidas" (SEIB, 2008, p. 23).

Philip Seib afirmou que a Al Arabiya estava tentando definir uma nova tendência para o noticiário árabe - nem tão suave refletindo a linha do governo e nem tão provocativa como a Al Jazeera. O porta-voz da Al Arabiya, Jihad Ballout, que já tinha sido o porta-voz da Al Jazeera, observou que a mídia tinha se multiplicado e agora tinha fontes melhores sobre o Oriente Médio (SEIB, 2008).

Dr. Mahmoud Hammoud disse que entre as mudanças que aconteceram depois do lançamento da Al Jazeera houve o surgimento de tentativas de competir com a Al Jazeera, como a Al Arabiya, mas que para ele falhou muito.

Apesar de se apresentar como independente como a Al Jazeera, era uma voz, uma porta-voz de pessoas que a sustentavam [...] Mesmo agora, especialmente durante tempos de guerra, eles não vão como a Al Jazeera apresentar o que as pessoas gostariam de saber e sim pontos de vista relacionados aos governantes pelos quais são sustentados. Além disso, novas mídias ocidentais surgiram na tentativa de competir com a Al Jazeera, a CNN começou uma transmissão em árabe, França, BBC de Londres iniciou um serviço árabe, os Estados Unidos, mas infelizmente não tiveram sucesso 
porque eles não comunicaram com a verdade que o povo árabe precisa ouvir (HAMMOUD, 2009).

Em 2004 o governo americano fundou o canal Al Hurra. De acordo com o presidente Bush, era parte de uma tentativa de cortar completamente o obstáculo da "detestável propaganda" gerada pelas emissoras árabes e proporcionar notícias e informações confiáveis na região (SEIB, 2008). Em 2006, o príncipe saudita Al-Walled ibn Talal lançou Al Resalah TV. Em março de 2008, surgiu o novo canal em língua-árabe da BBC. E a libanesa LBC, mais antiga de todas elas, vinha passando por um processo de evolução que refletia o amadurecimento da indústria de televisão do Oriente Médio.

Mas para o cinegrafista Laith Mushtaq, a diferença entre eles se vê no campo:

Os outros canais deveriam se perguntar por que as pessoas nos recebem em suas casas e não os recebem. É um relacionamento. Porque as pessoas acreditam que a Al Jazera transmite a verdade e tudo o que eles querem é a verdade. E é por isso que muitas vezes nós estamos mais perto da notícia, que em uma batalha nós somos os únicos lá (MUSHTAQ, 2009).

Sami Zaiden, quando questionado sobre os outros canais similares, diz que ainda não viu ninguém fazer parecido e nem consideraria possíveis canais lançados futuramente como concorrentes.

Eu nunca vi ninguém fazer o mesmo, transmitir em inglês de um jeito não ocidental [...] Quando você olha para o fluxo de informação no mundo, ele vai primordialmente em uma direção: do norte para o sul. Então, quanto mais canais puderem vir e reverter esse fluxo ou contribuir para isso, é melhor. Eu não acho que o lançamento de outro canal necessariamente competiria com a Al Jazeera, mas poderia complementar (ZEIDAN, 2009).

\subsection{Pesquisas de audiência}

Medir estatísticas de audiência de forma precisa é quase impossível - muita gente assiste TV por satélite de forma informal. Além disso, qualquer forma de censo parece estranha no mundo árabe, uma vez que os árabes mostram resistência quando alguém bate à sua porta fazendo perguntas intrusivas. Mas alguns institutos de pesquisa estudaram o público que assiste à Al Jazzera e outros canais e nos mostram os resultados.

Uma pesquisa conduzida em 2006 pela Zogby International, em que o grande público de diversos países árabes respondeu a entrevistas, analisa a preferência pelos canais de TV. Por meio dela, pode-se comparar o interesse pela Al Jazeera e pelas outras emissoras árabes. Foram entrevistados 3850 indivíduos nos seguintes países: Egito (800), Jordânia (600), Líbano (600), Marrocos (750), Arábia Saudita (750) e Emirados Árabes Unidos (500), com 
um intervalo de confiança de 95\%. Mais da metade deles (54\%) disse preferir a Al Jazeera a outros canais.

A figura 1 mostra a maior frequência de sintonizados, em todos os países de uma forma geral, em cada canal árabe.

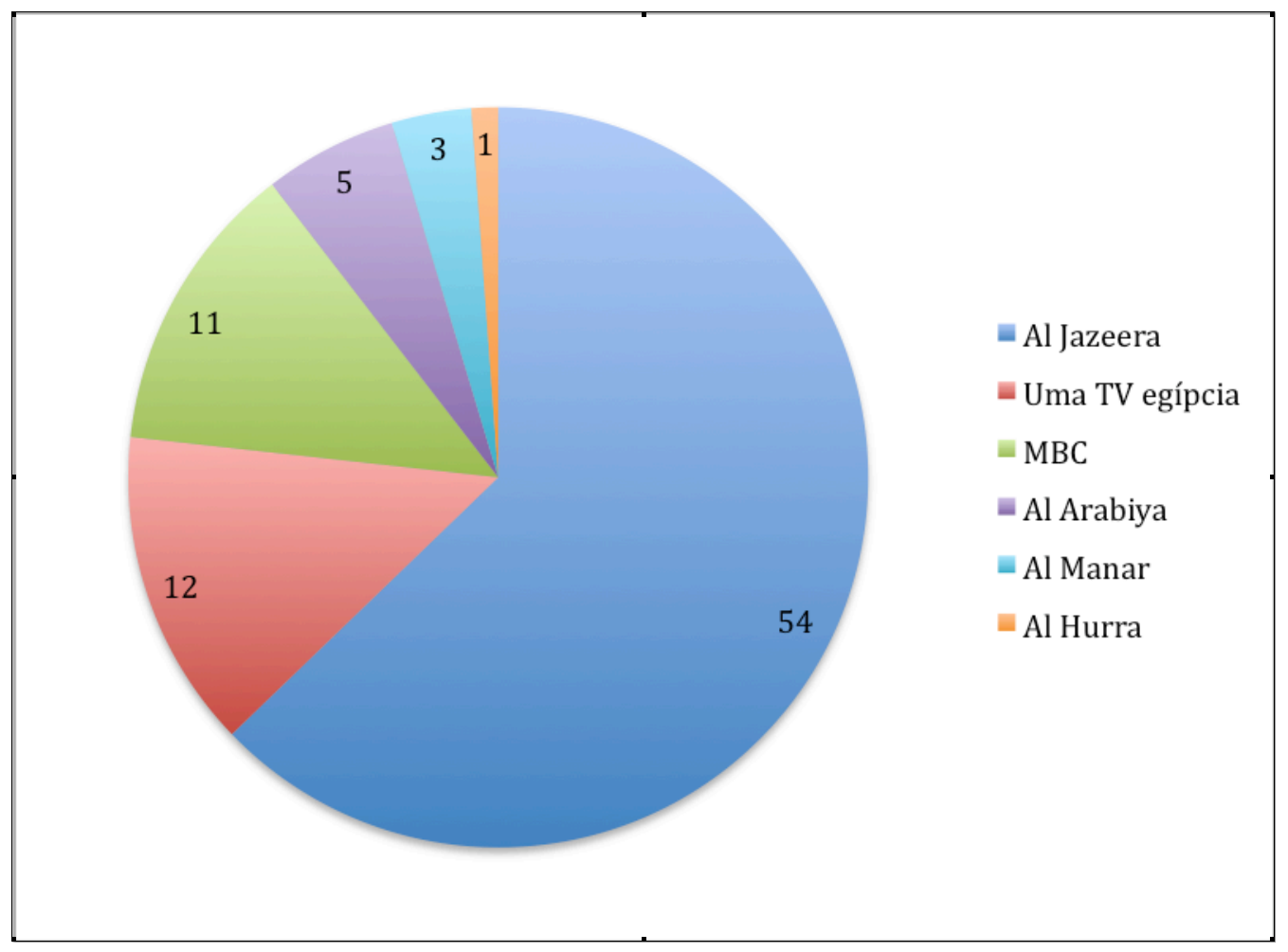

Figura 1. Distribuição geral das respostas à pergunta: Quando você assiste noticiário internacional, qual das emissoras de TV você assiste mais frequentemente? Dados em porcentagem.

A figura 2 mostra, especificando o país analisado, quais são as emissoras mais frequentemente sintonizadas nos canais árabes. 


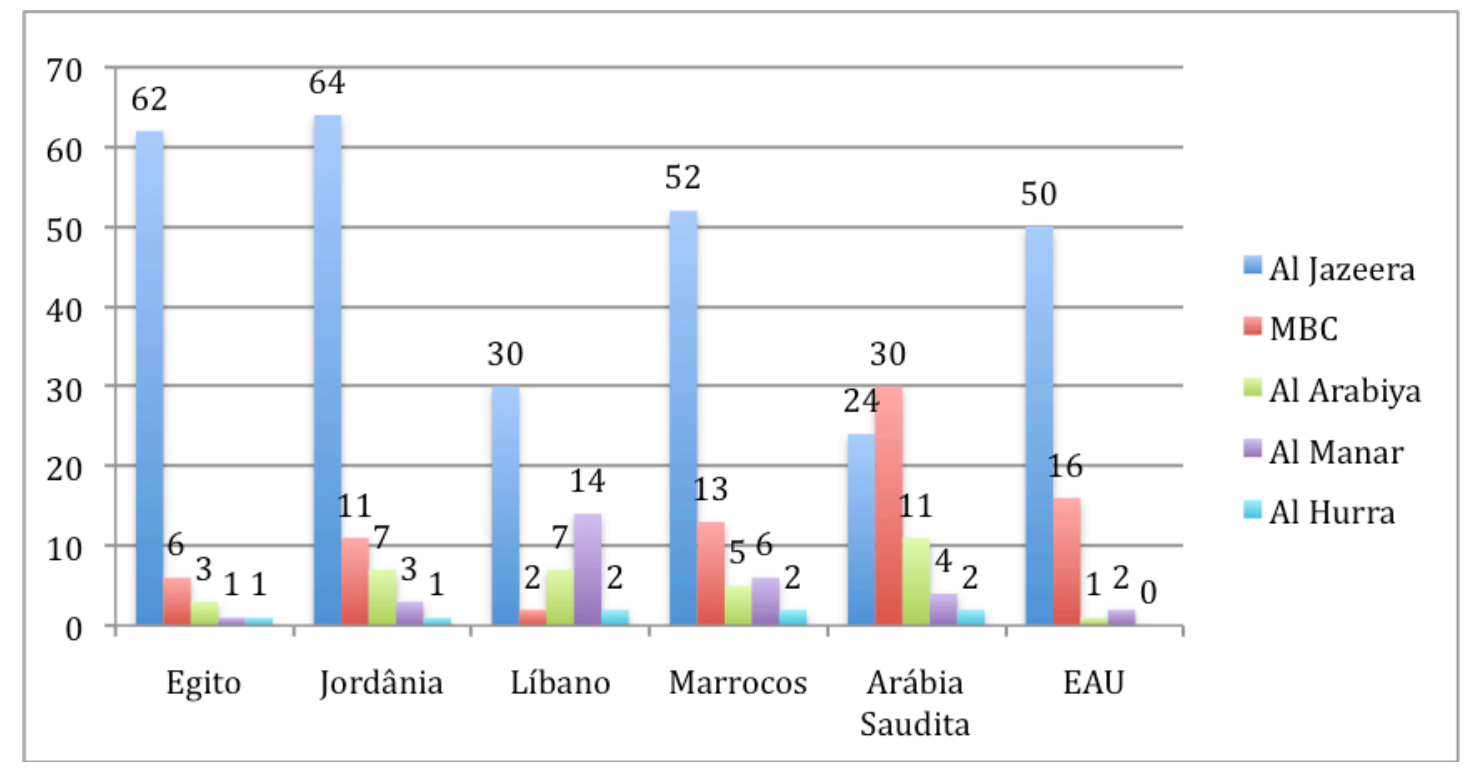

Figura 2. Distribuição entre os diferentes países das respostas à pergunta: Quando você assiste noticiário internacional, qual das emissoras de TV você assiste mais frequentemente? Dados em porcentagem. EAU refere-se aos Emirados Árabes Unidos.

Conforme demonstrado pela pesquisa, a Al Jazeera é líder absoluta de audiência no contexto dos países árabes como um todo. Quando a preferência do público é segmentada em cada país, a Al Jazeera continua na frente das outras em todos os lugares, exceto na Arábia Saudita, onde a MBC, que transmite as notícias, de Dubai, tem a preferência dos expectadores sauditas.

A figura 3 compara a audiência dos canais árabes perante o público que sintoniza a TV mais do que cinco vezes por semana. 


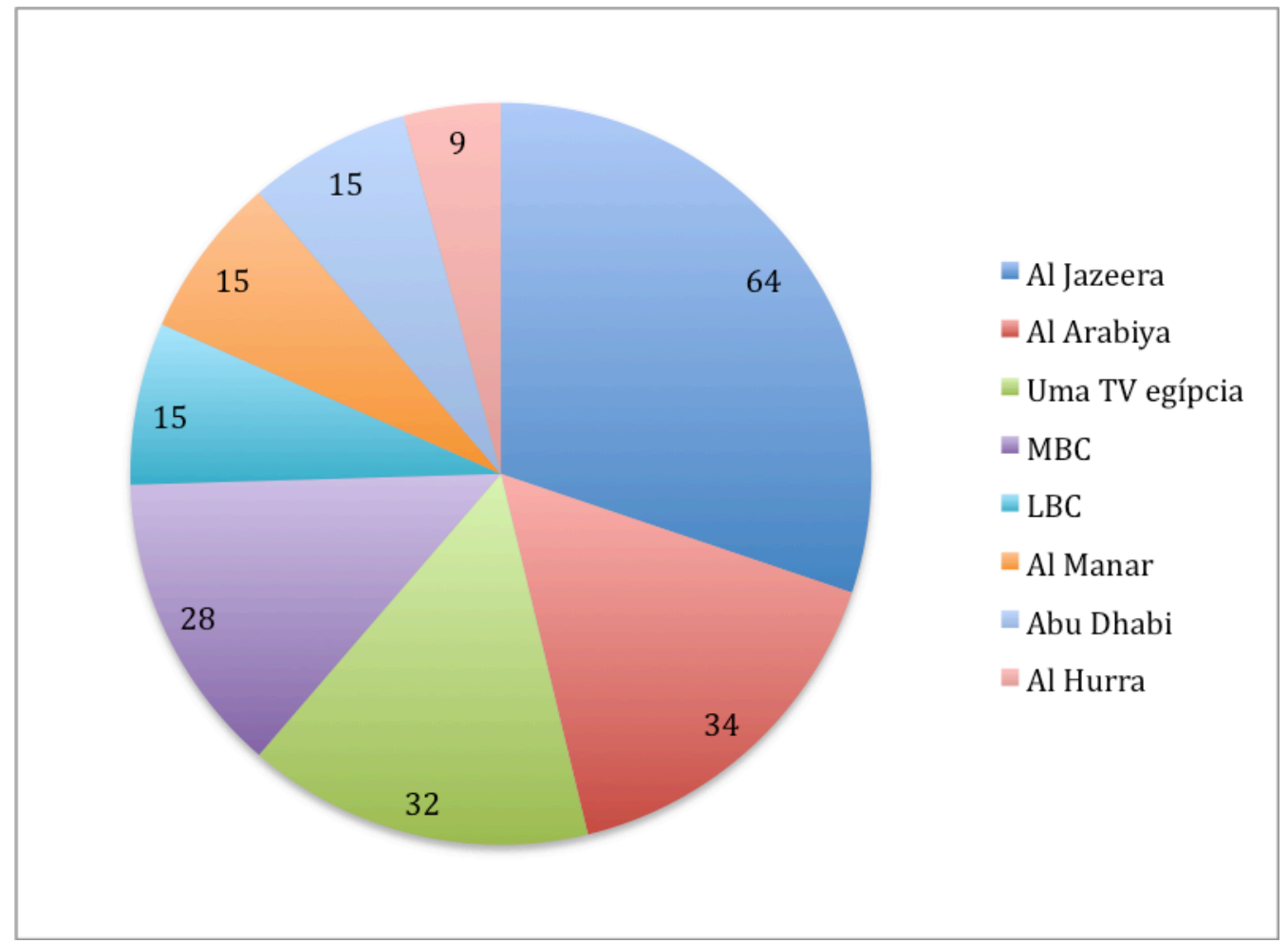

Figura 3. Distribuição geral das respostas à pergunta: Dos canais de notícia que você assiste, qual você assiste mais de cinco vezes por semana? Dados em porcentagem.

A figura 4 descreve a situação dos canais árabes sintonizados mais do que cinco vezes por semana em cada país pesquisado.

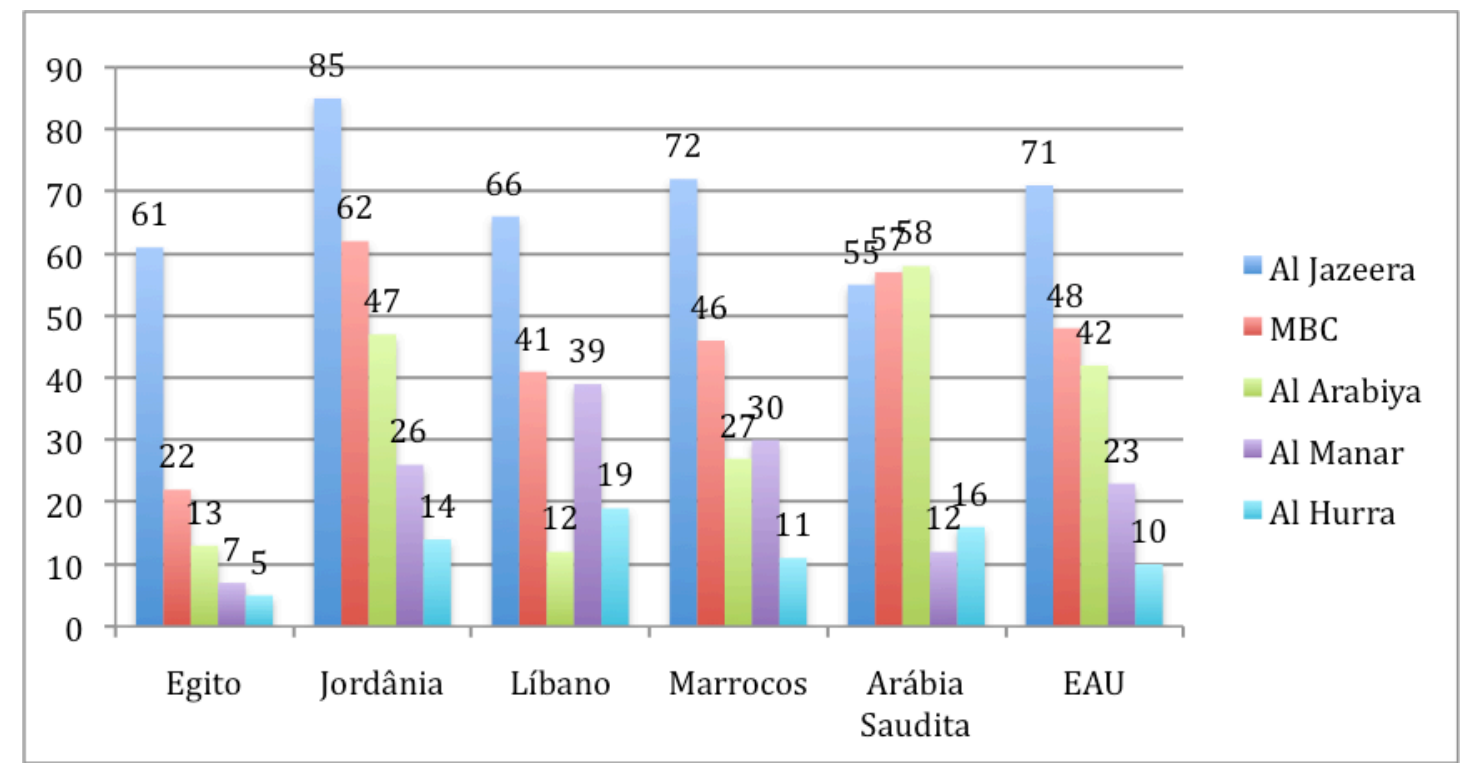

Figura 4. Distribuição entre os diferentes países das respostas à pergunta: Dos canais de notícia que você assiste, qual você assiste mais de cinco vezes por semana? Dados em porcentagem. 
A pesquisa demonstra que a Al Jazeera é líder no Egito, na Jordânia, no Líbano, no Marrocos e nos Emirados Árabes Unidos, mas perde a preferência na Arábia Saudita, onde está em terceiro lugar - atrás da MBC e da Al Arabiya.

Uma outra pesquisa, realizada na Alemanha pelo Spiegel, ARD-Tagesthemen durante o ano de 2006, avaliou o impacto dos veículos de mídia na formação da opinião pública. Este quesito foi medido contando-se a quantidade de vezes que ele foi citado em outras mídias. A figura 5 descreve os resultados desta pesquisa.

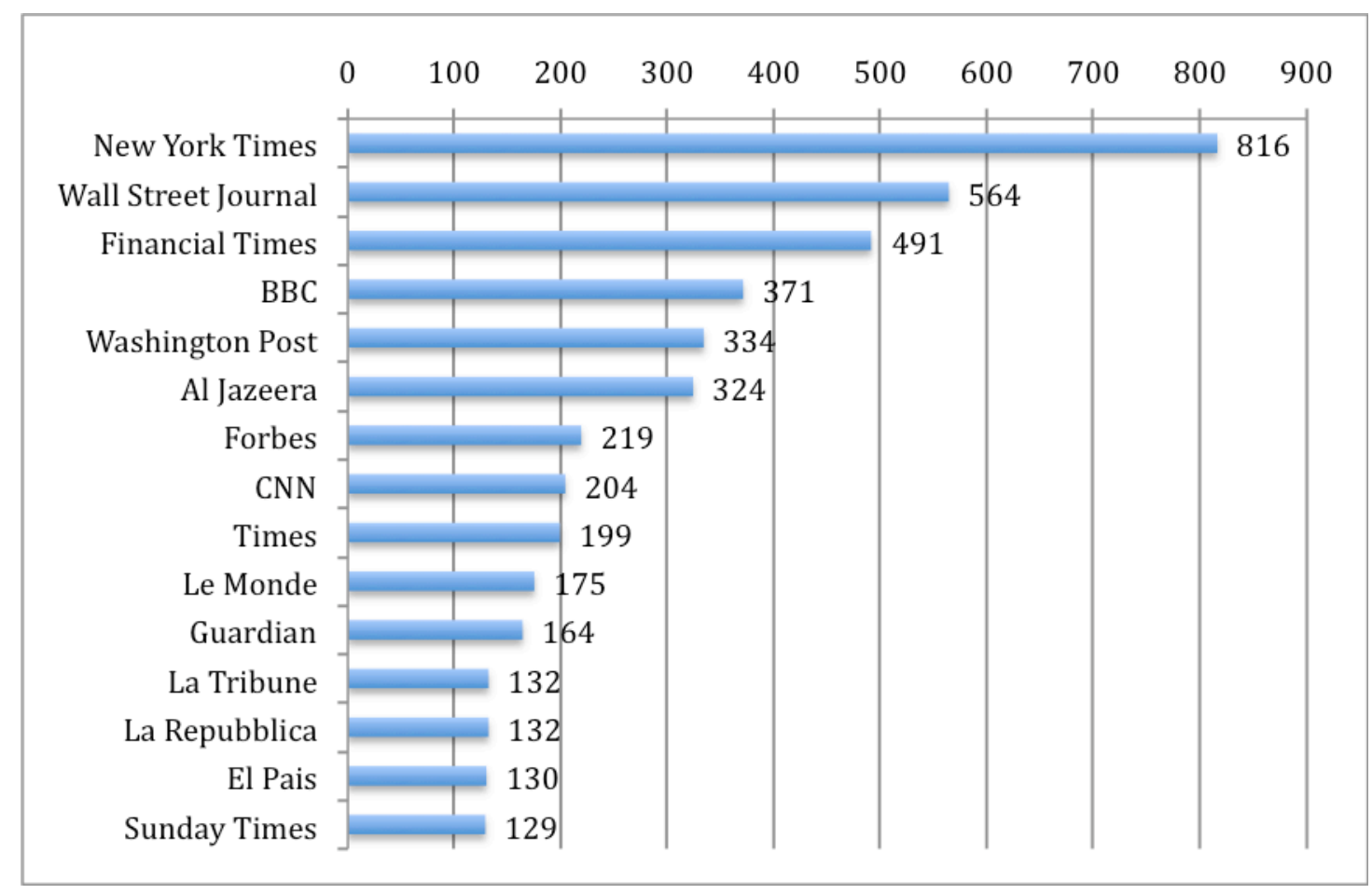

Figura 5. Veículos de mídia mais citados na Alemanha em 2006. Adaptado de 655 quotes in 39 german opinion leading media such as FAZ, Spiegel, ARD-Tagesthemen.

A pesquisa indica que a Al Jazeera foi o sexto veículo citado pelos alemães no ano de 2006 . O primeiro nome do ranking foi o jornal americano The New York Times. A grande ascensão da Al Jazeera aconteceu depois da cobertura das guerras no Iraque e no Afeganistão. Com o ganho de audiência, o canal árabe foi mais citado do que a CNN na mídia alemã, além de outros nomes consagrados na imprensa.

Um outro relatório da Universidade de Emory em Atlanta, nos Estados Unidos, avaliou quais são os países que aparecem na pauta de algumas emissoras de TV norte-americanas e na da Al Jazeera. 


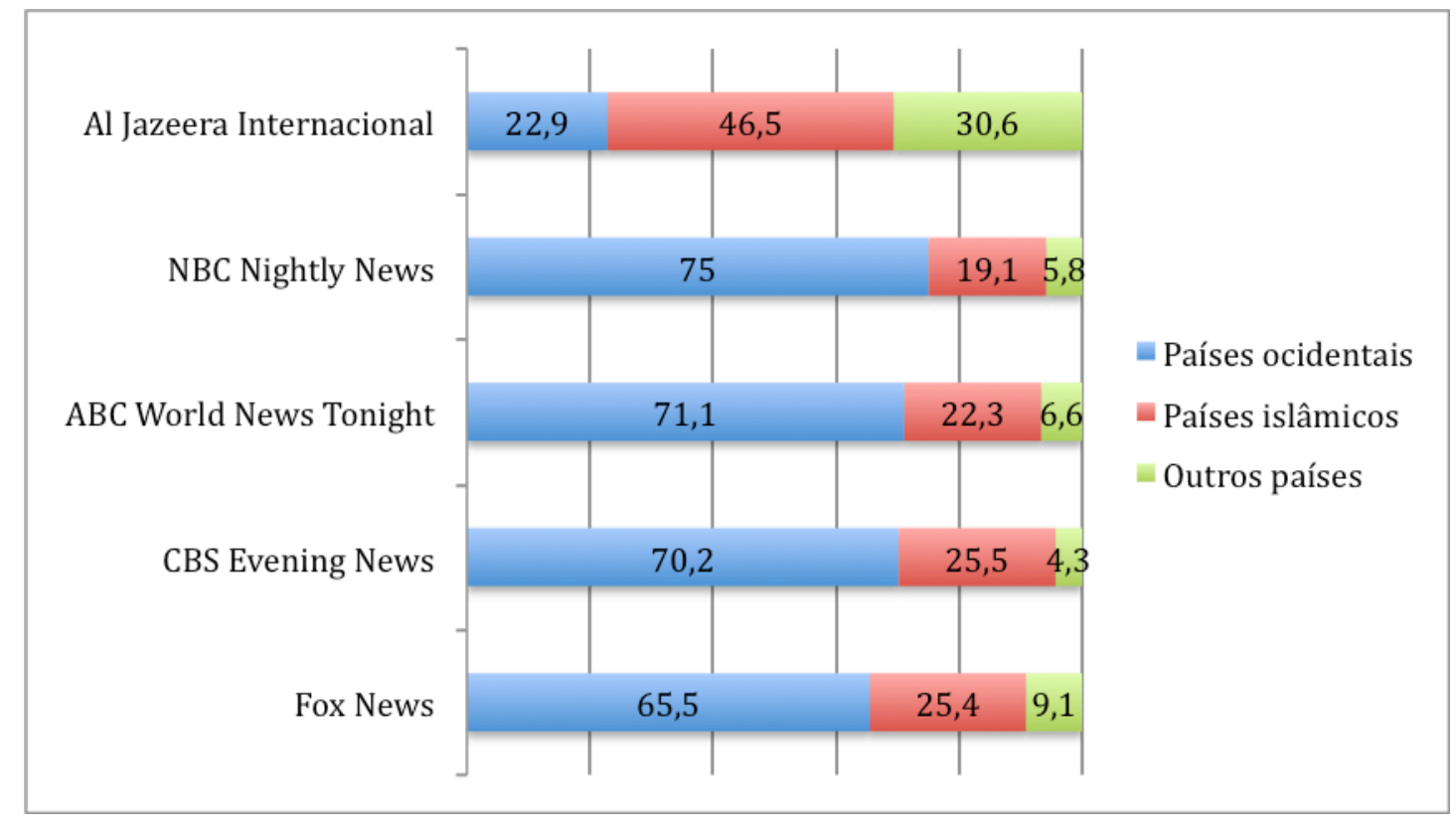

Figura 6. Divisão percentual entre países citados no noticiário da Al Jazeera International e dos principais telejornais noturnos norte-americanos entre novembro de 2006 e janeiro de 2007. Dados em porcentagem.

Por volta de 2/3 das notícias divulgadas nos Estados Unidos são notícias da América, de 20 a $25 \%$ notícias de países islâmicos, principalmente do Iraque. O resto do mundo tem pouca relevância nos meios de comunicação americanos. Até mesmo a Al Jazeera international apresenta um horizonte mais largo. O canal árabe é o que mais se dedica em sua pauta a países islâmicos.

$\mathrm{Na}$ figura 7, a mesma pesquisa analisa quais são os temas abordados pelas mesmas emissoras e como eles são distribuídos dentro da programação de cada canal. 


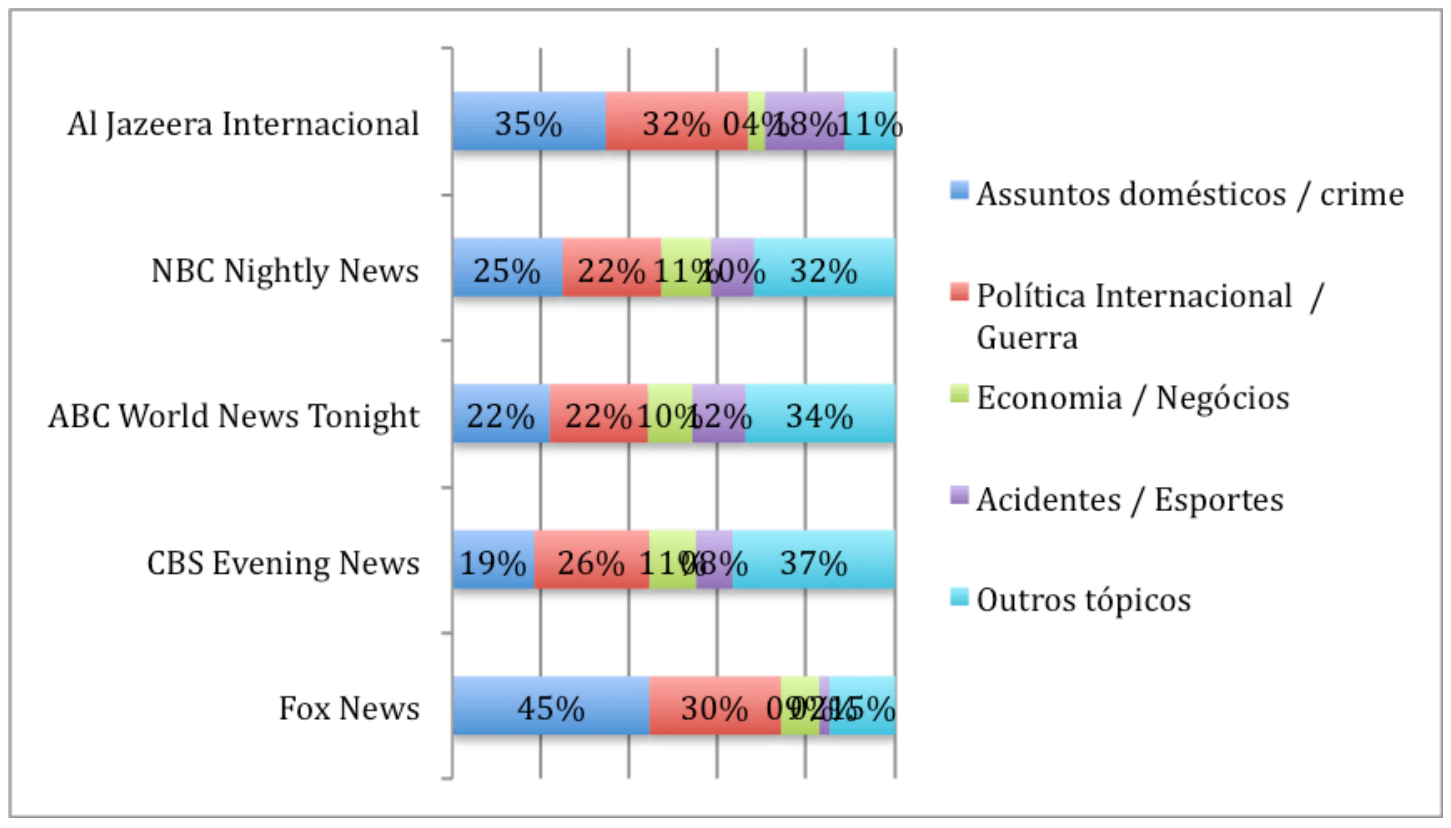

Figura 7. Divisão percentual entre temas citados nas notícias dos principais telejornais noturnos norteamericanos entre Novembro de 2006 a Janeiro de 2007. Dados em porcentagem.

O canal em inglês da Al Jazeera é o que mais se dedica a assuntos relacionados à guerra ou a política internacional. Apesar de seu formato pan-arabista, a emissora árabe também é a segunda que mais volta boa parte de seu conteúdo para questões políticas internas, perdendo apenas para a Fox News.

A figura 8 mostra o quanto o tema religião apareceu nas notícias da Al Jazeera international e dos principais canais de notícias em alguns países.

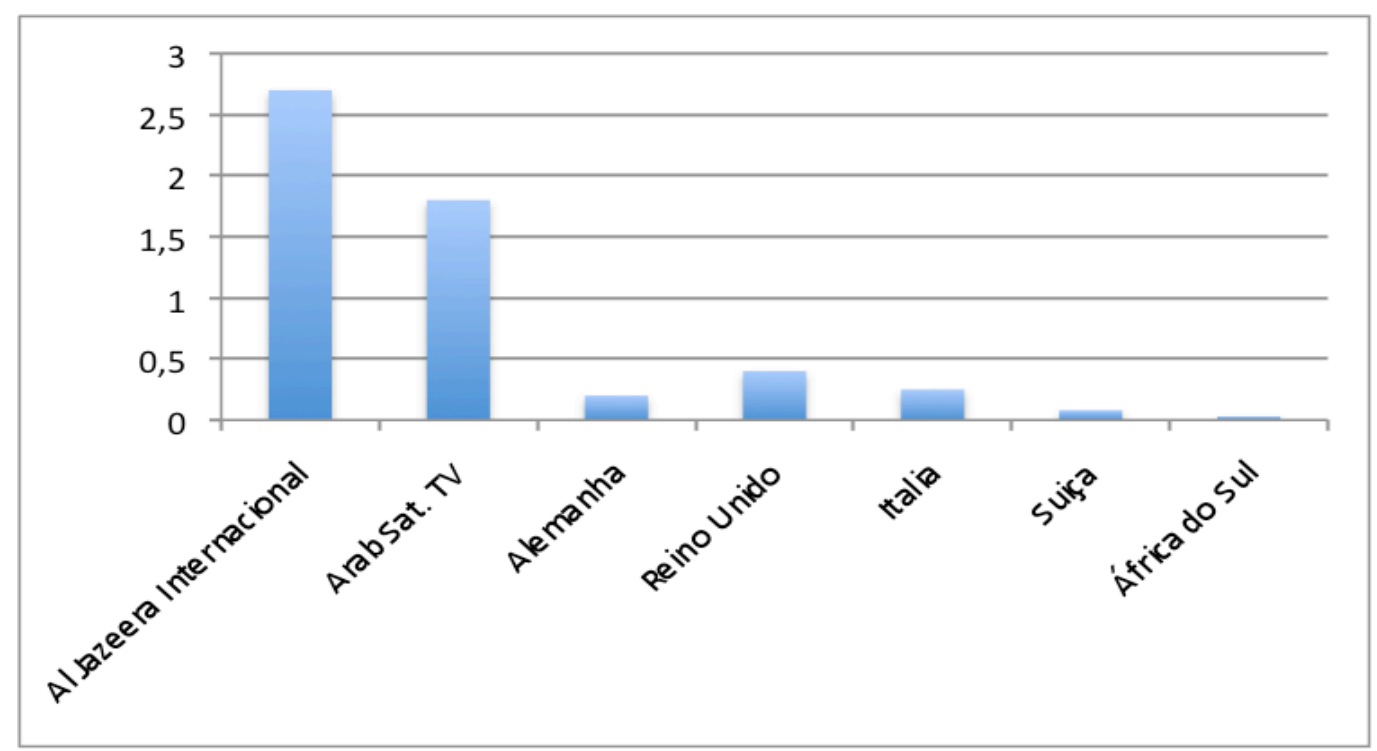

Figura 8. Porcentagem que o tema religião foi noticiado na Al Jazeera International e nos principais canais de notícias em diferentes países em fevereiro de 2007. Dados em porcentagem. 
Percebe-se que a religião aparece tanto no canal em inglês da Al Jazeera quanto no principal canal da Itália.

O estudo também aponta se a religião aparece de forma positiva, negativa ou neutra, conforme descrito na figura 9.

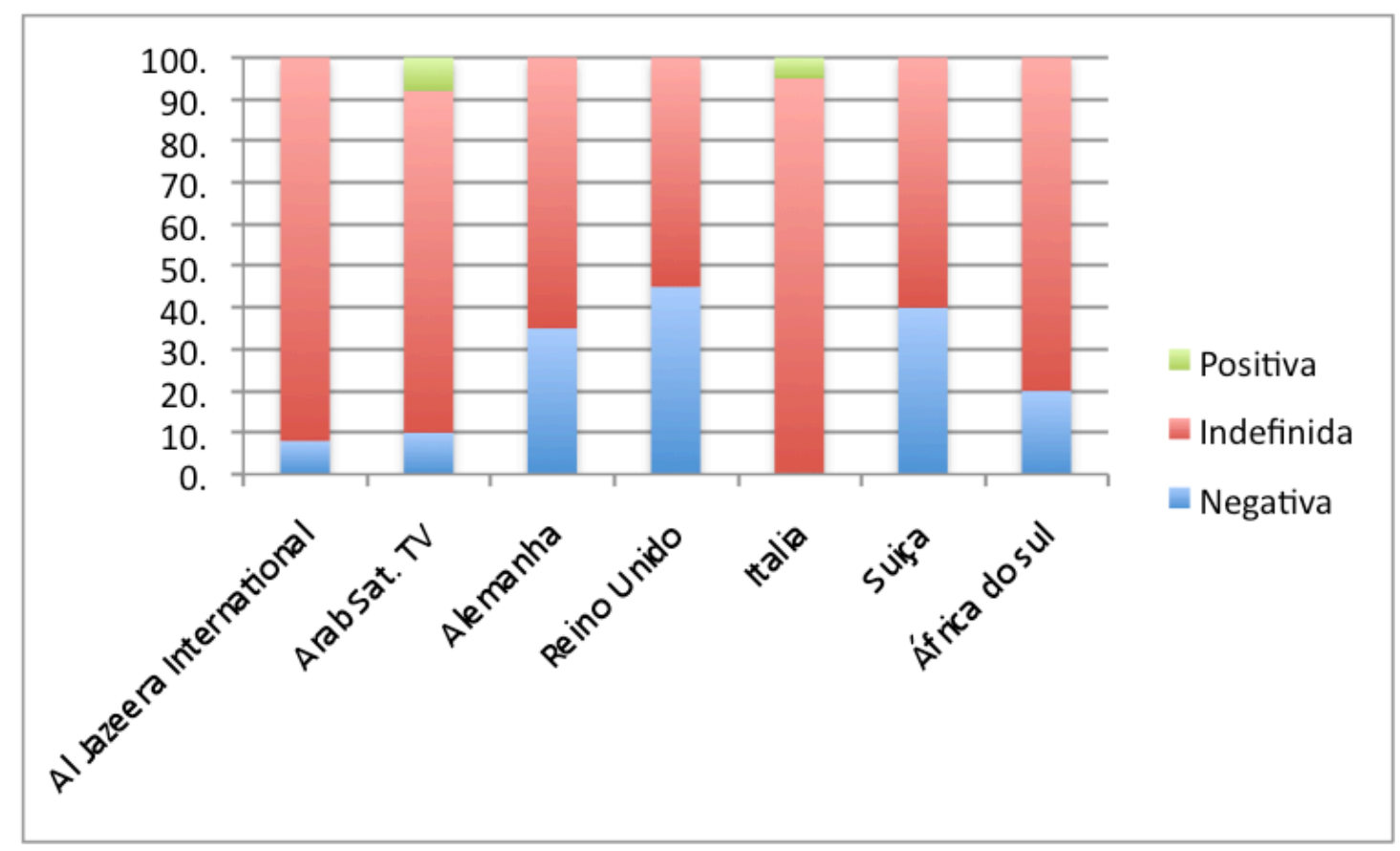

Figura 9. Divisão percentual da perspectiva sobre os protagonistas do tema "Religião" da Al Jazeera International e dos principais canais de notícias em diferentes países em fevereiro de 2007.

Nota-se que a religião aparece na Al Jazeera international de forma indefinida, em sua maior parte, e em algumas situações de forma negativa, mas que em momento algum ela aparece positivamente, como acontece na Itália. 


\section{Considerações finais}

Neste estudo sobre a Al Jazeera, pudemos observar todo o contexto que envolveu o surgimento da Al Jazeera, como a rede de TV mudou o cenário político e social da região e de que forma ela conseguiu crescer e se estabelecer no mercado de notícias apesar das inúmeras dificuldades que teve que enfrentar.

A sociedade árabe do Catar era bem diferente antes do lançamento do canal. O antigo XeiqueKhalifa Bin Hamad Al Thani, que ficou no poder desde a independência do país, em 1971, até 1995, governou de forma conservadora, mantendo as tradições e limitando os avanços. Em toda a região do Golfo, via-se o mesmo autoritarismo que contribuía para caracterizar a sociedade como atrasada em relação a outras regiões.

O difícil acesso à informação deixava a população alienada do que acontecia no mundo e com poucas chances de se comunicar com seus iguais. As principais fontes de notícias eram veículos estrangeiros que transmitiam os fatos com um olhar predominantemente ocidental. A imprensa árabe se restringia a cobrir a agenda de seus monarcas.

Após o golpe de Estado que colocou o Emir Sheikh Hamad Bin Khalifa Al Thani no poder, uma era de grandes mudanças surgiu no Catar. A mais relevante delas para este trabalho foi a criação de um canal de notícias em árabe, produzido em Doha, que revolucionou a TV, a imprensa e a política. Pela primeira vez, os árabes podiam assistir aos telejornais com a cobertura internacional do dia na sua própria língua. Essa forma de comunicação estabeleceu uma nova relação entre os árabes e o resto do mundo.

Esta pesquisa também mostrou que foi a cobertura de guerras que de fato lançou a Al Jazeera no mercado internacional de produção televisiva. Com as fontes a seu lado e consequentemente os acessos privilegiados, o canal conseguiu fazer imagens exclusivas e reportagens diferenciadas, que foram retransmitidas por outros canais internacionais e percorreram o mundo.

Os vídeos enviados por Osama Bin Laden à Al Jazeera pouco tempo depois dos ataques ao World Trade Center, nos Estados Unidos, foram exibidos pelo canal e renderam durante muito tempo uma repercussão sem limites que tinha sempre o nome do canal destacado nas discussões sobre o Oriente Médio e o mundo islâmico. 
A fama também veio aliada a críticas. Além das reações negativas do Ocidente, a cobertura das guerras na primeira década do século XXI gerou descontentamentos no próprio mundo árabe. Ao mesmo tempo que ganhava projeção, o canal enfrentava rejeição e problemas diplomáticos. Tudo isso contribuiu para consolidar o lugar conquistado no mercado e fortalecer o objetivo de mostrar os fatos por diversos ângulos, dando oportunidades para todos os envolvidos no tema de expressar suas opiniões.

A audiência seguia respondendo à escolha do canal de privilegiar a cobertura dos acontecimentos nos países árabes e islâmicos. Em 2001, durante o período pós-11 de setembro e na Guerra no Afeganistão; em 2003, com a Guerra no Iraque; em 2009, com a grande ofensiva em Gaza; e em 2011, durante a Primavera Árabe, a Al Jazeera parou sua programação para transmitir, 24 horas por dia, as notícias dos conflitos. Foi também durante esses períodos que o canal árabe expôs contradições e recebeu críticas.

Pudemos observar que por meio de uma cobertura diferenciada, inserida em um contexto de poucos debates, a emissora conseguiu se expandir. A criação de um canal em inglês, em seu décimo aniversário, ampliou consideravelmente o número de seus espectadores. As discussões continuaram em torno da identidade da Al Jazeera, que passou a ter um novo público, de modo que tenha buscado se adaptar aos interesses dessa população na busca de notícias.

E com apoio da internet e de outros canais, a Al Jazeera se tornou em poucos anos uma das maiores redes de comunicação do mundo, concorrendo com gigantes consolidadas no cenário midiático há décadas e fomentando o aparecimento de outros canais intencionados em disputar a mesma audiência.

Durante toda sua história, a Al Jazeera conseguiu trazer novos elementos para o universo em que está inserida, assim como produzir um efeito imediato na política local e nas relações interpessoais e internacionais a partir de suas escolhas. O mundo árabe descobriu uma nova realidade e desde então vem se adaptando a ela, beneficiando-se, acima de tudo, das consequências positivas desse novo cenário.

Voltando um pouco no tempo, podemos relembrar que as ideias liberais do iluminismo no século XVIII saíram da Europa e percorreram o mundo, mas demoraram a chegar a alguns países árabes, sobretudo os países localizados na região do Golfo. "Não concordo com uma só palavra que dizes, mas defenderei até a morte o seu direito de dizê-las" é uma célebre frase atribuída ao filósofo François Marie Arouet, mais conhecido por Voltaire, que defende, entre 
outros temas, o direito à liberdade de expressão, ainda totalmente desconhecido por alguns cidadãos no fim do século XX, quando surgiu a Al Jazeera.

Depois de uma história repleta de conservadorismo, com anos de ditadura e pouca abertura a debates e discussões, os países dessa região do mundo localizada entre o mar vermelho e o mar do Golfo, chamada de Península Arábica, tiveram o primeiro contato com diversidade de ideias com a chegada da Al Jazeera. Os árabes puderam experimentar pela primeira vez a sensação de ouvir em árabe o que de fato nunca gostariam de ouvir e ao mesmo tempo o que sempre tiveram vontade de dizer.

A partir de então, a sociedade deixou de ser tão refém dos governos autoritários e começou a vivenciar um processo de transformação, que segue adiante ainda que enfrentando alguns obstáculos. As mudanças que vem ocorrendo nos países árabes são frutos de um novo pensamento difundido na região com a mesma velocidade com que a internet e as novas tecnologias avançam no ocidente. E continuam acontecendo progressivamente sem previsão de término.

A contribuição dos meios de comunicação, sobretudo dos novos meios de comunicação, nessa evolução da sociedade árabe é evidente. Mas é necessário que ela seja ainda maior para que a região possa continuar sua caminhada rumo à modernização e à abertura. Ainda há problemas e deficiências na política e consequentemente no universo midiático que restringem os avanços sociais. Por enquanto, pode-se dizer que este momento atual é o começo de uma nova era. A Al Jazeera conseguiu até agora transformar de alguma forma a realidade de muita gente e tem potencial para impulsionar ainda mais os cidadãos árabes em direção ao futuro. 


\section{BIBLIOGRAFIA}

ABC NEWS. Al Jazeera is real news. 2011. Disponível em: $<$ http://www.youtube.com/watch?v=FvjmCTygW5I>. Acesso em: 28 Fev. 2013.

AL-HAMMOURI, L.; GALAL, I.; MOWAFI, A. Operation Iraqi Freedom or Invasion of Iraq: Arab Interpretation of $\mathrm{CNN}$ and $\mathrm{Al}$ Jazeera Coverage of the 2003 Gulf War. Transnational Broadcast Studies. Cairo: The American University in Cairo, 2004. Disponível em: <http://www.tbsjournal.com/galal.htm>. Acesso em: 28 Fev. 2013.

AZAR, J. Entrevista I. [jan. 2009]. Entrevistador: Gabriela Santos Lian. Doha, 2009. A entrevista na íntegra encontra-se transcrita no Apêndice A desta monografia.

BAKHTIN, M. Estética da criação verbal. São Paulo: Martins Fontes, 1997.

BARKHO, L. The Arabic Al Jazeera Vs Britain's BBC and America's CNN: Who Does Journalism Right? American Communication Journal, Charleston, v. 8, n. 1, p. 1-15, 2006. Disponível em: <http://ac-journal.org/journal/vol8/Fall/index.html>. Acesso em: 28 Fev. 2013

CHARAUDEAU, P. Discurso das mídias. São Paulo: Contexto, 2006.

DOW, N. Entrevista II. [jan. 2009]. Entrevistador: Gabriela Santos Lian. Doha, 2009. A entrevista na íntegra encontra-se transcrita no Apêndice B desta monografia.

EL-NAWAWY, M.; ISKANDAR, A. Al-jazeera: The Story Of The Network That Is Rattling Governments And Redefining Modern Journalism Updated With A New Prologue And Epilogue. Cambridge: Westview Press, 2003. 
EL-NAWAWY; POWER, S. Mediating Conflict: Al-Jazeera English and the Possibility of a Conciliatory Media. Los Angeles: Figueroa Press, 2008. Disponível em: $<$ http://uscpublicdiplomacy.org/projects/AJERP\%20el\%20Nawawy\%20\&\%20Powers\%20No v\%205.2.pdf>. Acesso em: 28 Fev. 2013.

FARAH, P. D. O Islã. São Paulo: Publifolha, 2001.

FIGENSCHOU, T. U. Courting, Criticism, Censorship and Bombs: The Bush Administration's Troubled Relations with Al-Jazeera Channel from September 11 to the War in Iraq. Nordicom Review. v. 27, n. 1, p. 81-96, 2006. Disponível em: $<$ http://www.nordicom.gu.se/common/publ_pdf/226_figenschou.pdf $>$. Acesso em: 28 Fev. 2013.

GABALLAH, A. Entrevista III. [jan. 2009]. Entrevistador: Gabriela Santos Lian. Doha, 2009. A entrevista na íntegra encontra-se transcrita no Apêndice C desta monografia.

HALL, S. A identidade cultural na pós-modernidade. Rio de Janeiro: DP\&A, 2006.

HAMMOUD, M. Entrevista IV. [jan. 2009]. Entrevistador: Gabriela Santos Lian. Doha, 2009. A entrevista na íntegra encontra-se transcrita no Apêndice D desta monografia.

HOURANI, A. Uma história dos povos árabes. São Paulo: Companhia das Letras, 2006.

KHANFAR, W. Al Jazeera and the Arab Spring. Chatham House, Londres, 2012. Disponível em: <http://www.chathamhouse.org/publications/papers/view/181515>. Acesso em: 28 Fev. 2013.

KHANNA, P. O segundo mundo. Rio de Janeiro: Editora Intrinseca LTDA, 2008. 
LYNCH, M. Voices of the New Arab Public: Iraq, al-Jazeera, and Middle East Politics Today. New York: Columbia University Press, 2007.

MILES, H. Al-Jazeera: The Inside Story of the Arab News Channel That is Challenging the West. New York: Grove Press, 2005.

MORAES, R. S. O discurso sobre o mulçumano na imprensa brasileira: o caso da revista Veja. 2011. 203 f. Tese (Mestrado) - Faculdade de Filosofia, Letras e Ciências Humanas, Universidade de São Paulo, São Paulo, 2011.

MUSHTAQ, L. Entrevista V. [jan. 2009]. Entrevistador: Gabriela Santos Lian. Doha, 2009. A entrevista na íntegra encontra-se transcrita no Apêndice E desta monografia.

PAINTER, J. Counter-hegemonic news: a case study of Al-Jazeera English and Telesur. Challenges, Oxford: University of Oxford, 2008. Disponível em: $<$ https://reutersinstitute.politics.ox.ac.uk/nc/publications/risj-challenges/counter-hegemonicnews.html>. Acesso em: 28 Fev. 2013.

SAID, E. W. Covering Islam: how the media and the experts determine how we see the resto f the world. London: Vintage Books, 2007.

. Orientalismo - O Oriente como invenção do Ocidente. São Paulo: Editora Schwarcz LTDA, 2007.

SALAMA, V. Al Jazeera's (R)Evolution. Jadaliyya, 2012. Disponível em: $<$ http://www.jadaliyya.com/pages/index/5610/al-jazeeras-\%28r\%29evolution>. Acesso em: 28 Fev. 2013. 
SEIB, P. The Al Jazeera Effect: How the New Global Media Are Reshaping World Politics. Dulles: Potomac Books Inc., 2008.

SCHATZ, R. Widening the Perspective: Al Jazeera International Enriches Media Landscape. Atlanta: Arab Media Center, 2007.

TATHAM, S. Losing Arab Hearts and Minds: The Coalition, Al Jazeera and Muslim Public Opinion. London: C Hurst \& Co Publishers Ltd, 2006.

TV AL JAZEERA. Al Jazeera director general steps down. 2011. Disponível em: $<$ http://www.aljazeera.com/news/middleeast/2011/09/201192012481969884.html>. Acesso em: 28 Fev. 2013.

TV AL JAZEERA SATELLITE NETWORK. The Al Jazeera Decade 1996-2006. Manama: Al Waraqoon W.L.L., 2007.

VAL, M. Entrevista VI. [jan. 2009]. Entrevistador: Gabriela Santos Lian. Doha, 2009. A entrevista na íntegra encontra-se transcrita no Apêndice F desta monografia.

ZAYAni, M. (Ed.). The Al Jazeera Phenomenon: Critical Perspectives on New Arab Media. Boulder: Paradigm Publishers, 2005.

ZAYANI, M.; SAHRAOUI, S. The Culture of Al Jazeera: Inside an Arab Media Giant. Jefferson: McFarland \& Company, Inc. Publishers, 2007.

ZEIDAN, S. Entrevista VII. [jan. 2009]. Entrevistador: Gabriela Santos Lian. Doha, 2009. A entrevista na íntegra encontra-se transcrita no Apêndice G desta monografia. 
ZINGARELLI, M. E. The CNN effect and the Al Jazeera effect in global politics and society. Washington: Georgetown University, 2010. 


\section{APÊNDICE A}

Transcrição da entrevista concedida por: AZAR, Jamil - news presenter, Chief Language Monitor and member of the Al Jazeera editorial board.

G: How do you think Al Jazeera achieved this success in a short period?

I was in the former time of Al Jazeera. We started in 1996 and I think we achieve success immediately when we went on air because first of all we introduced a new kind of journalism in Arab media. And also because we, journalists, have had the opportunity to work in a free source of atmosphere from an Arab country. And this is because the Emir of Qatar Sheikh Hamad Bin Khalifa Al Thani has given us this opportunity and we approve as Arab journalists that we can do our job professionally when we are given the tools and the freedom to work professionally. So, the circumstances of the time, when Al Jazeera came into being, we were also perfect for something like Al Jazeera, a media like Al Jazeera to work, to operate, in the Arab world. Our approach to coverage of news was different from all others Arab media. Why? Because we have started to give the other opinion. As we know, Arab regimes controlled and still control media, but because Al Jazeera did not have any censorship, we were doing our job professionally, we manage to attract the attention of the audience and our audience started to grow and grow and I think we improved and we are credible and reliable source of information. So we started to compete with other media, specially the western media, which monopolized the hole seeing, media seeing, for decades before. And we prove we can do the job as well as them.

G: What are the differences between you and the western media?

I think one important difference is that we started to cover the news from a different prospective, from their prospective. They looked at it from western eyes. But we stated to give opinion, angle to the news. Audience is not only the Arab world, but outside started to see things on their screen which they never see before. That made us a quite difference from the other media. Because have being covering developments in Arab countries, and in Muslim countries and Asia and Africa, we started to deal with areas which see hot developments. Look at Arab world, look at Middle East, look at Asia, wherever you look... have wars. So we can't, as a 24 hours news channel, we cannot ignore them, because there are 
developments there that concerns to a lot of people. And this was not covered by the media, I would say, western media. CNN, BBC, they didn't cover these issues as we did, because we look them from a different angle, they have their own ways to cover the news.

G: You created the motto "one opinion and the other opinion". Tell me about this.

Our motto "one opinion and the other opinion", is still our motto and you see it on our screen all the time. In fact, you are talking to the man who compose, if you like, that motto. I was the one who wrote it down and proposed and it was accepted by the board of directors, the former board of directors. And we still hear. And that's how we started to talk to our opposition. Arab opposition and non-Arab opposition. But to talk to Arab opposition and project their opinion and their position of all issues is something you can call revolutionary for an Arab media, an Arab country. That was basically one of the factories which let to our success and achievement in such a short time. Not only that. We have also started to interview Israeli politician and Israeli journalists and analysts which was not the kiss before we came along (???). So wanted to be objective and balanced, informative because they are part of the scene, the Israelis are part of the scene in this region. I think we still adhere to this until now, we still interview Israelis as we did last week with the president Peres, the Israeli president. So, our motto is "one opinion and the other opinion". It sounds a little beat strange in English speaking word to hear the opinion and the other opinion, because before Al Jazeera there was one opinion, in every issue, and that was the opinion of the governments of the regimes. When we came along we introduce the other opinion, and that was very very important source step for the Arab media.

G: What is the relationship between Arab people and this media?

We don't speak for anybody. Because we are from an Arab country we know how the street, how the public in Arab countries feel about issues which concern them, concern their lives, theirs children, their future. And therefore, we really touch on, if you like, subjects, developments, or influence that affect this people. And therefore, perhaps if you go to any Arab country and ask them about Al Jazeera, they will say... ohh Al Jazeera, this and that and so on because they like Al Jazeera and they watch Al Jazeera... It isn't a sort of agreement with them that we do. But it's because they feel that we are feeling a gap and we are providing them with honest, reliable service, giving them the right information, of being at the places of news and so on. Also, don't forget that we allow them to talk to not only our presenters, but with our guests, in our programs, live, on air, they can phone and put their 
opinion and express their opinion. Mubasher! That is something which was new in Arab media. Again: we still do it, people can phone and make a dialogue with guests, politicians and put questions. And that's why we have been described by some quarters that we represent an Arab parliament on air. And this is very flattering.

G: I know that you have Americans, British...in the newsroom. Aren't you afraid of loosing this feature?

Of course I am talking about the mother channel, which is the Arab channel, and because we talk to Arab audience, we need Arab journalists. Therefore, most of our journalists in the Arab channel are Arabs ou speak Arabic fluently and very clearly. When Al Jazeera English came along on November 1996 obviously we expanded and we became a network of the channel, for Al Jazeera English they can have anybody who speaks English. So they might have journalists from Canada, from USA, from Britain, from India, from Pakistan and so look and speak English. But very few journalists who are not Arab can speak Arabic properly and fluently in order to be able to work in the Arabic channel. So we are not worried about losing our features and I think as long as we adhere to our motto "one opinion and other opinion" and to adhere to our code of ethics, which we have put as guideline to journalists and editors and so on, I think there is no worry about loosing our identity.

G: Which is the most important difference between the Arabic channel and the English channel? Even though I don't speak Arabic fluently I can see that they are different. Now, for example, on the Arabic channel is just war on Gaza and on the English channel there is everything.

I think that is wrong to expect that Al Jazeera English should be a copy of the Al Jazeera Arabic. Why? Because Al Jazeera English speak to an audience different from our audience, Arabic channel. Those audience speak only English, in England, America, Canada, Australia, Asia, Europe...they have different culture, not only culture but different cultures as well and therefore how you address them? Should be, by the nature of the audience, should be different from the Arabic channel and that's it. Also the issues that interest the Arab audience maybe different in lots of cases from what issues interest the Indian audience, or audience in USA or Canada or Europe.

G: Do you have any research about the audience profile?

Actually we don't have so far, we don't have a department, audience research department I worked for BBC for 31 years in London before I join Al Jazeera in 1996, I came over here 
before we went on air, we prepared, trained journalists and I think in that cense I've tried to think about the...(???)

In BBC there was an audience research department, which deal to all the feedback, letters and so on. On those there was no internet, mobile and those kind of things. Al Jazeera we get our information a lot of feedbacks from our viewers, but we don't have a kind of department which do this in detail. I hope it will come, sometime we will have such a department, but we don't have. Last years we asked a number of academics and researchers and so on and they provide us a very interesting report about Al Jazeera and about how people think of it and so on about our programs and news coverage, there are very interesting remarks, we as editors or people in charge of the editorial side of things we were first of all interested in knowing that there were these remarks and also surprised because some of them we didn't agree, I mean, there were criticism but we didn't think that there were right and others we agree with them, as a policy, we admit, if we make a mistake we admit that and we declare, we are human beings, so we can make mistakes.

G: Why do you decide to put on air scenes that show blood, more than the others?

We don't do that. But such circumstances need or compel us to show such scenes, in other words, to show the atrocities and the awfulness of killing people of wars and so on. Now, we found that we have been criticized because of that and we found that those who criticized us do the same whenever they like. Take the BBC, for instance. When there was attack in London they keep on showing the same story and people being killed and all these kind of things. I don't if they were criticized as we had been. But frankly speaking I find that criticism of Al Jazeera it's not objective, it's not on real logical ground and it seems that we have some antagonist who just criticize Al Jazeera because we are different.

If the picture we are showing is too awful sometimes we put camouflage on this. We really would like to present the news as news is. This is the way we could influence people and show people killing and violence is awful. Some people say: it shocks the viewers and so on but war is shocking. We know what is to be killed and bombed, killing of children, is awful.

G: How do you decide being 24 hours talking about a war, like Afghanistan 2001, Iraq 2003 and Gaza 2009?

It's like our coverage of any news story. If the news story is wear of putting on screen we put it. Now the war on Gaza, the war on Iraq, these wars are very very important to our audience and because we cover the Arab world and Arabs audience outside the Arab world, in Europe, 
in America, we are 24 hours, there is always somebody somewhere in the world who want to watch and see what's happening. Because we are universal, we don't only address the audience in the Middle East. We serve audiences in all over the world, in all countries we have audiences.

G: Is difficult to broadcast 24 hours about one topic? What kind of problems do you have when you choose talk about a war?

If we cannot get in touch with our correspondents... the news agencies, it isn't only our correspondents. We get the reports and show pictures they provide. As much as others use our own pictures. CNN, BBC...that's why you see Al Jazeera logo on their screens. They use our pictures and we use some of them. Of course we have discussions with experts and analysts.

G: What kind of words you use in Al Jazeera and the others don't use. In Brazil, it's common to hear the word terrorism, for example.

We use, but we qualified. Specifically in the case of terrorism, we are still waiting for the United Nations to come up with the definition of terrorism. Because terrorism in one mind is different from another's. Does the resistance to occupation is it called terrorism or selfdefense or what? Ask the Israeli, they will say, yes, they are terrorist. Ask the Palestinian, they say, no it's resistance, it's allowed in international law to fight occupation. And therefore if we say terrorism, we say what is called terrorism, or what he described as terrorism. And therefore isn't us that say this is terrorism. It's what Shimon Peres says this is terrorism, or what Tony Blair says this is terrorism or what George Bush says it's terrorism, so we qualify that. Armed man, group, fighters...

G: You said you don't have censorship. What about self-censorship?

We don't have any official censorship, there is no interference of governments, they don't have any Ministry of Information. In all Arab countries there is the Ministry Information, there is somebody who is from the government watch over the news, we don't have here. But obviously all media, all journalists and journalistic coverage we have standards to adhere with, to be honest about things, to be courageous, to be also sympathetic to people's feelings, private considerations like religion, and we adhere to this like any other responsible media. That's the only self-censorship we have. If we thing that some language is kind of offend somebody we don't use it, its common sense.

G: Why don't you talk about Qatar? 
Qatar is a very small country. And most of the people here are not Qataris. Like me, I'm not a Qatari. And the Qataris who are involved of the politics of the country are minority. If you think about this, there's very little development and news generated in the country, but we have never, if there was anything newsworthy in the country we put on air, we project it. How much do you hear about (???). There's a country called Andorra, is Spain. It's a country. Anyway, if there was any news story from Qatar, worth projecting, we will put it. Visits of leaders or conferences, world conferences in Qatar we cover. Other than that there is very little we can talk about. Specially, don't forget we are in tribal society here, and the Qataris are very loyal to the Emir, they are really very loyal to Emir, and therefore there's very little trouble, I mean, there isn't trouble. There was once and we cover that. One of his relatives was in a little trouble and we cover that. Other than that there is very little to talk about.

G: How do think about the coverage of Brazil or Latin America?

I must admit I am not an expert on Latin America news or culture. I know something about Da Silva, as a president, as a leader, Amazonia, it's coffee, but that doesn't mean I follow details of Latin America or Brazilian affairs. However we have an office in Caracas. That's why we started to attract Arab audiences outside Arab world. And we realized also that there's little coverage of Latin America news. Before at the time of Sandinistas and all that kind of war in Central America, that's very old, now we have in Arab media generally very little coverage of Latin America affairs. But now we are following these developments more closely than it used to be and perhaps that's not enough 


\section{APÊNDICE B}

Transcrição da entrevista concedida por: DOW, Nazar - editor of Inside Story Arabic and English.

G: What is the biggest difference between the English and the Arabic channel?

The biggest difference between the two channels is that they are directed to different viewers and that's the base of what you see: the viewers are different. The Arabic channel is of course directed only to Arab viewers and the English channel is directed to international viewers who speak English. That affects everything to do in the production in both channels. It's a main guideline.

G: when you came here, five years ago, you've seen a growing up of the channel. How do you see this growing up...

When I join the Arabic channel was already established. And then the project of the English came about. We were asked to work at the English as well. I work at both at the moment. I am the only employee in the company who works for both. The main reason for the differences is that, there lots of similarities too, for example, now we are sharing pictures fully, so it's a tv station, pictures are the most important thing, we are using the same pictures practically, if any of the channels manage to get the pictures in the end it will be ownership of the network. So everybody else can use it. How to use them? To what extend to use them? In what context use them? Is of course allowed to any journalist wherever he is in this channel and still the main guideline is your viewers you could do ten hours of Gaza in the Arabic channel of the same material you get four hours at the English channel because the viewers are not the same. Simple. This is the reason of everything else.

Now, during Gaza War, the Arabic channel is 24 hours.

We did the full coverage, now it's getting down, by the way. It came about the same. I run two programs: one called Inside History, Al Jazeera English, and xxxx, Al Jazeera Arabic. So we decided from day one in both that will be doing Gaza for the war as long it might last. We did 24 shows half hourly Al Jazeera Arabic and we did 24 Al Jazeera English. The time was the same. The angels different a bit everyday according to viewers as well. This is the thing: 
there is no other thing. The thing is viewership. Every editor, every people person responsible is really to decide what his viewers want to watch.

G: Which is more difficult?

The English channel because the viewership is international. You are not a channel direct to England. You speak English and you are not from England. If it were direct to England it would be simple, we just do it for England, like Sky does or BBC does. We are direct to the world. There are people in India, in Latin America, in Africa, they are happy to speak English. So you have to involve their interests and their desires, what do they want to watch. There is no system to evaluate that, so it's our guess, of course, using the feedback and the information we know, trying to read the politics, but it is an editorial at the end.

G: Have you seen some difference since the beginning?

There is some changes. It's not changes, it's development. It's more aware of its abilities and its reach, it's more stable and looks relaxed in to the vision, we don't look worried about what we are saying. At the beginning we did look a bit little. We have people from about 60 nationalities, they are different, they are very different. But through the time culture of the places develops. I join them, you fit in, the system, there is a system running. Here, you come in, you want to participate in making the system, which is a bit difficult. Now is being a slow down, even the people will join us, now join something that has some kind of a culture. It's development. The totally of the people make the culture, generate what would be in the future called Al Jazeera English culture. It's in the making. It's still not really fully ready but it's the making, I can see development. I enjoy being part of that. 


\begin{abstract}
APÊNDICE C
Transcrição da entrevista concedida por: GABALLAH, Ayman - newsroom's chef.
\end{abstract}

06:22 I'm here since the launch, 1996. For three years I left and I came back later 2004.

G: How do you find this phenomenon?

07:00 I didn't find a phenomenon. Because when you are part of a thing you might not discover, you might not realize, how people are looking at it. You are just doing your work and you do not watch the impact, when you are concentrating in your work. You think that you are doing something very normal, very natural, this is your daily routine and this is your daily challenge. But from time to time when you raise your head and you meet people coming from outside telling that you are doing something different, actually you are doing your work.

08:07 This is the thing: before I joined Al Jazeera and since I was graduated on Mass Communication College, I had this dream of doing this job the way we thing is the right way, because it was always the wrong way. And when I came to Al Jazeera and my colleges came from other channels we were all in one way of thinking. We just did the way we think it should be done. Some of us were comparing with Western media and looking it as an idol: this is the example of how to do the perfect media. Day after day, month after month, year after year, we've discovered the challenge was bigger than what we have thought. It's not to do a copy of Western media, it' not to do a replication of Western media with an Arabic flavor or Arabic culture or Arabic perspective. No! It's the dream we had is not existing all over the world. We are thinking about ideas which is not implemented in any places. Maybe the Western media is more closer to what we think of at the time, I mean 1996. But when we tackled issues which was a matter of conflict of interest, with the regimes all at the West as well, we've discovered the West is dealing with this issues the same way the Arab governments dealing with their issues. There's no freedom, there's always just one view allowed to be on the screen, there's no tolerance on listening to other opinion. So we've discovered that the dream we are looking for still very far away so we have reach our own way. Not just like this channel or the other channel, no. Because we've discovered that all of us have our own problems, so we have to tackle our problems our own way. 
11:53 way of thinking needs to be spread all over the Arab world, not only in Al Jazeera. It needs to be on the culture of the people. And people need to understand that this is part of the right way of convening information. We need this message to be common in Algeria, Egypt, Morocco and everywhere. There is still many challenges. 


\section{APÊNDICE D}

Transcrição da entrevista concedida por: HAMMOUD, Mahmoud - Professor of Qatar University.

G: How do you see the relationship between the Arabs and the media in the East?

M: People here are aware of the media, aware of the events that happens around the world because we are at the center of the world and events happen here and touches everybody's life. For example, my kids, they are just young and they ask me what's happening in Palestine now, in Gaza, and why the Israelis are killing children, because they hear about it, they see it on television, on Al Jazeera, so they get interested to know what's going on. So we, as people in general, we get involved and we get interested to know what's going on in the world. The media is not strange for us. So people at young age they get interested in public affairs and issues and the media is one source of information that they seek and they would like to know from besides the parents and the friends. Al Jazeera is a new phenomenon that started 10, 15 years ago and since it started Al Jazeera became first a world phenomenon because as you know the media was controlled by Western views. Most news agencies, most television networks, most newspapers are Western oriented. CNN, Time Magazine, Newsweek, Reuters, all this what is called a north view of the world. So there is no point of view coming from the south or from the third world countries. Al Jazeera broke that monopoly of the news. And it started first Golf War in Iraq and since then Al Jazeera became like a world phenomenon but it became like representative of which country, meaning Al Jazeera became a national media. People in every Arab country seek information, they don't trust on other media, they don't trust government media, Al Jazeera provide them an alternative point of view that they were not used to hear before. Al Jazeera became the national media for every Arab country, for every Arab citizen, for Iraq, for Qataris, for Palestinians, for Lebanese, for Morocco, for Mauritania, all Arab world Al Jazeera became like national media for them because their national media not provide them with the news and information that Al Jazeera was providing.

They did not trust on media because the media was controlled by the governments, and governments, in general speaking, they are not trustable, because they give whatever they think, right for them, not for the truth. People will not receiving the full picture from their 
own media. Al Jazeera came with the whole and new idea, that they are listening to things that they were not listening to before Al Jazeera. So Al Jazeera became very popular among Arab country. And everybody, specially in times of crisis, everybody tends to Al Jazeera. Crisis like wars and conflicts, here and there, every time there's some big problem.

G: What has changed after the launch of Al Jazeera?

There was attempts to compete with Al Jazeera. One other network, Al Arabiya, but it failed very much because although it represents itself as an independent like Al Jazeera but it was a voice, month piece of the persons who support it. So did not get out of the box of representing certain Arab government views. Even now, specially during war times, so they will not representing like Al Jazeera what people would like to know, it was representing points of views related to the governments that they are supported by the station. Besides that, they were attempts to compete with Al Jazeera from Western news media, CNN started an Arabic broadcast, France, BBC London started an Arabic service, the US, because they accused Al Jazeera of being a month piece of Bin Laden and terrorist because they were not happy with what Al Jazeera is broadcasting, so they wanted to represent their point of view but unfortunately they did not succeed because they did not communicate with the truth that the Arab people need to hear.

They think that Al Jazeera is broadcasting point of view that is not in line with their policies, so they want to present a different point of view that is in line with their policies which is the Arab pill are sick of, they don't want to hear.

If you say something on air, and the truth in the ground is different, for example, you can say that Israel is a democracy, but then you say what they are doing in Palestine, how can you convince Israel is democracy? It doesn't work. CNN try to do that, BBC, they are representing Western point of view of events. These channels try to compete, but they will not succeed, because they are not representing the reality underground. You can say everyday America is democracy, and all of us in Arab world we love America, and people love to be Americans and they love American way of life, but they don't like American policy in the Middle East. If you tell them American is a democracy but then you prevent us from practicing our own democracy, in our region, it's not gonna work. You say Israel is a democracy, but then Israel is occupying us and they kill people, Hamas was elected democratically by people, but they don't allow Hamas to rule, just because they don't like the policy of Hamas. I mean, you can divide democracy according to you liking, if democracy 
doesn't work in your favor, you have to accept that there is. But you can't impose whatever you want.

G: Do you think the Royal family is involved in Al Jazeera?

M: my information from Al Jazeera inside that nobody dictates what they broadcast. The events dictates what they broadcast. Sometimes they show something that probably the Qatari Royal family are not happy with, but they show sometimes. People speak on Al Jazeera which means Al Jazeera broadcast freely. Now, something called self-censorship I don't know how much that happens because sometimes people are aware... In general, they don't interfere in the editorial policy of Al Jazeera. People in Al Jazeera decides based on events and news whatever they want to broadcast.

I've seen sometimes some critics of Qatar on Al Jazera, at the same time is being criticized for allow Israelis on is channel. Many Arabs thing it's not fair, to show the victims at the same amount of time.

It's not they want Al Jazeera to show Palestinian point of view, but we fell offended as people, I'm speaking, when we see Israelis just killing our children. Of course, we fell offended if they just find not only on Al Jazeera, but in other channels because there is no excuse. What they say the concept of objectivity which means, when we teach our students we say: objectivity you have to detach yourself from the news, you have to present all point of views, if you like it or not, with equal fairness. And you have to present only facts, we cant present emotions, that's what we teach to our students. But reality is no objectivity in a hundred per cent, even CNN claim to be objective and they show two points of views, but sometimes by omission the news, or by focus in the news on certain things your are not objective anyway.

At on time on CNN there was a small picture chose destruction of house by the Israelis. Now the same picture appeared at Norwegian newspaper but the Norwegian newspaper's picture shows a woman sitting with her hands on her cheeks. It was her house. The same picture was broadcast on CNN but without the woman. The woman was cut of. If you evaluate the two signs, CNN broadcast the news, the Norwegian newspaper broadcast the news, but there is a human element in the newspaper from the Norwegian. They associated the destruction with the sadness of the woman and what happened to her house. CNN cut the human element of the news. This is the objectivity. You are objective, you showed the news, the truth, but the truth is not complete in that part. Just a small piece of information that makes a big difference. 
M: On 1983, The New York Times, on first page: Terrorists attack Israeli military in south of Lebanon. Most of Americans don't know where is south of Lebanon, they think is part of Israel. The news looks nice. They are telling events like it is. But the word terrorists and if you know where Israelis are, how can you call those terrorists? They are occupiers. If you are invading another countries territory and somebody from there attacks you, you are the one who's terrorist. The same about the West Bank. They don't say occupied territory. Most of Israelis think the West Best is part of Israel. That's the Western point of view of events. So Al Jazeera did a good job in presenting the other point of view.

G: Which words does Al Jazeera choose and the others doesn't?

When they speak about Gaza, they say resistance in Gaza, while they say terrorists or similar labels. Of course there's a big difference. If you are resisting and that's the truth because Israelis they are invading Gaza... When Al Jazeera talk about West Bank they say Occupied West Bank, the Israeli Defense Forces Al Jazeera would say Israeli Army. What Israelis are doing in the South Lebanon, in Gaza, in Wets Bank is not defense, is occupation. Labels and descriptions make a lot of difference in the news. People get affected by them. In the international laws they are occupiers. If you label them as occupiers is what they are. The West Bank is not part of their territory.

G: On Al Jazeera the pictures are stronger.

M: I think it's ironic. This is the truth, isn't it? When people are suffering in war that is what happens. CNN and alike claim that Al Jazeera and Arab culture they don't mind showing blood and stuff on the channel. It's not the truth. The truth is that the events are happening. Al Jazeera sometimes they don't show everything. Of course they show a lot of destruction and people suffering which reflect the truth that is happening. Now CNN, during Iraq war, when some Americans were killed, they didn't show because they said their viewers are very sensitive to see blood. That's an insult to Arab culture. We are very sensitive to blood too. But the truth is underground when the blood is spilled. That is what is really happening. The American Defense Ministry, they forbid any American media from showing funerals of American soldiers in Iraq. Is it because Americans are more sensitive than Arabs about funerals? That is not truth. People are sensitive. The same. And that's the truth: the funeral of Americans killed. And that's the truth about wars: people get killed, civilians or military person. But of course we know why: because they did not want people to be against war. When you don't show, probably you don't get affect, and you forget. Is just a number. A 
picture is very effective. We say a picture is one thousand words. When you see bodies, and people killed, and children get killed and soldiers get killed too, that's war. But when you don't see that on television you think it's a concept of a clean war. You just go in and occupy country, no destruction, no casualities, no damage... people get reacted when they see pictures but they did not want people to know the truth. Americans they lost a war in Vietnam because of television. Because images of war were coming to American homes. They think people get against the war because what was happening on television. But nowadays you can't hide anymore. With a small camera, you can edited and people get aware of that.

M: I know that American people are very nice people. And if they see the truth they would not probably support Israel. But because they don't get the full picture of what is happening in Palestine all they say it's propaganda: Israel is the only democracy in the Middle East. Israel is like us and the Arabs are terrorists, and they don't care about the killing of their children. We are like any other people.

G: Do you discuss about it with other academics in Arab world? Is there a lot of other point $\mathrm{f}$ view?

M: Of course there are different points of view, but the general pictures is like what I am saying.

I don't watch the Al Jazeera English very often, I do watch it but not very often. I heard from people saying Al Jazeera English is close to CNN with some kind of difference. I understand why. Because they are trying to reach the Western mind. The way you reach Arab audience is different from Western audience. I know it myself because I am multicultural. I am American citizen, by the way. Myself. I lived in America in 12 years.

G: How do you see Brazil, I don't know if you fallow Brazilian's coverage about wars or about Arab countries...

M: I do not know much about them there but I believe that they are affected by American policy, although the policy recently in most of American countries are anti-American, in general. Your president is not like by the American administration. Chavez and Venezuela and Bolivia... there has being changed in these countries and these countries are getting out of control of American. But, in general, I think the people are affected by American point of view of events. There is no Al Jazeera alike in Brazil, right? So you get points of views from America and Western societies about us. 


\section{APÊNDICE E}

Transcrição da entrevista concedida por: MUSHTAQ, Laith - cameraman.

G: what do you think about this difference?

L: the cameraman work in a battle or hot area is different then the other cameramen, he should be more active, more quick, should have a training and information about the war, to deal about this places because sometimes the shoot happen one time.

The duty of a cameraman working in a war is different than the others because is not only photos for news, is more important. It's document.

He is writing history by his eyes because there is many cases between different countries they use the photos.

It's different than normal work. In a war its a document, so its a big duty and also there's many side effect for these photo's, for the cameraman because finely he is a human when he works between bodies and innocent people killed like children. I was in Feluja, Iraq, and I saw a lot of things.

G: which was the worst thing that you saw in your life because of your job?

I saw a lot of things, you cannot image. The first shot in Feluja, a grilled man, he was in car, because the American forces attack the car and the car burn and he was burn, he was cooked, grilled, and I was in front of him and holding the camera, the smoke and the small...it's so difficult. And I still remember there's a family 24 persons, woman and children they attacked in a house, also in Feluja. I still remember there's kid he was holding a small car but his face was cut like a piece of cake, all the bodies there and only the father was alive, the father was talking with the son: stand up give me a hug or something like this. I was moving by the camera between the father and the dead body and from the dead body to the father. After one month, may 2004, my college was killed beside me. Rashid, my assistant we was together, I was shooting the roof of the building at night, there's a battle between militia and the American forces, the journalist was with us and many people and I asked to move down and he refuse. He said: I will stay with you. He was holding my shoulder and I was shooting. When the first shoot come to my side, I said: Rashid, I think they will attack us. And after that I fall down holding the camera and I saw Rashid on the floor. I cannot move. I hold his feet 
and said: Rashid, Rashid. The first thing I did: I hold the camera and take a shoot for him. After that I took him to the hospital and drive his car to Bagdad to his family. So this thing make a damage inside the cameraman. That's why all the cameraman working in conditions like this they should have to seat down with someone, phycologist, doctor, someone, take arrest because it stress. They are human, you cannot imagine, sometimes when I pass near in front shops that sell meat and when I smell meat, what kind of image took to my mind? You when you are watching tv and see photos, film, you can turn off the tv and you can change the channel also. But us, as a cameraman, we live on it, smell, sound and we saw everything there it's difficult

G: do you have fear?

Well...no...I am ready to go again. Because it's a message. There are some people that should be there, with those people. We had a training before and we know how to deal with it. The cameraman in the war is $60 \%$ soldier and $40 \%$ cameraman. We can move between the military people and this sound missile? It's necessary. To protect ourselves and to protect the college with us. We have information how to deal with these things. And finally some people should be there to record these things, to show the others theses things. Can you imagine, now, if there is no camera in Gaza? No one would know what happen there. Because as journalist, some people write on magazine or newspaper I can saw anything, But with photos no one can say maybe, it's fake. No, now we have something to show. And that's why when we press button on the camera it's a big duty, and we know we are recording for history, to save those people...

G: What's the difference of Al Jazeera and the others TV network?

I don't want to say that we are the best, we are the great. There's many colleges in many channels they are great and I respect them. Ok, this is our angle working in the news and we thought we try to do the best and to serve the news, and to be honest to the people and to transfer what happen around of us when we are in the field. No one force me as a cameraman to shoot this thing or not to shoot this thing. And if one day someone say this to me I will quit. Because I refuse it. We don't create the things we just record everything happening around of us. To serve the news and to serve the audience. I believe in Al Jazeera and I believe the idea and Al Jazeera.

Also the others, I respect them. It's like a garden.

G: as a cameraman of Al Jazeera, do you have a different way to do your job? 
If you talk about the style of course. Style of lighting, style of the angle, yes. For example, the $\mathrm{BBC}$ use the close up in the interview and we use the medium shoot. Inside the war you need to shoot, there's no time to... I'm closer to the news, yes. Sometimes there's some battle we were only there, no one with us. In felluja, we were alone and there's no channel in Felluja and if the people welcome us to be there so it's not our business. The other channel should ask themselves why people welcome us there and don't welcome them. It's a relationship. Because the people believe Al Jazeera transfer the truth and all they want the truth. And that's why sometimes we are more near of the news.

G: what has changed after the death of your college?

I had training before, I was cameraman in army, 6 years. And when I finished my service I work as a freelancer. Al Jazeera gave me a chance and this is what I love in Al Jazeera. Al Jazeera don't try to find famous people, famous cameraman, the most famous journalist. No. just accept normal people when they test them. They discover: ok, there's a good point in those people. And after that they give you a chance. And when they give you a chance you feel that they trust you, I will do my best and it start to be a relationship between us and Al Jazeera. Al Jazeera it's not this building, manager and newsroom, and walls and tables, no. For us, Al Jazeera is kind of a spirit. Something gave me a chance to work, and something I know, if something bad happen to me, they will defend me. We are a family. And for me Al Jazeera is an idea, because before Al Jazeera we hadn't media like this in Arab countries, in Arab world. There was only government media and that's it. But people like those working in Al Jazeera, I mean this kind of idea, this spirit of work, trying to discover things and all behind things people talking about it on street but you can not watch on tv. Al Jazeera put you and me, and my mother and my family and everyone seat down in one room and keep chating. About politics, religion, everything. So it's something new. Ok, now after 12 years.

G: Were you here all these years?

No, I started in 2003, the end of the war in Iraq. I started in 21 may 2003, after days when everything finished in Bagdad. But before that I was in...when the son of Saddam was killed, I was there. And in Fellujah, it was a big operation, inside Felluja more then 45 days. All the days in Bagdad, more than one year, is important, there was a lot of thing happening there. I traveled every villages and cities in Iraq. And when Iraq government closed our office there, I moved to Doha and I stay here one month, I had a training... After that I stayed in Afghanistan and traveled between many cities, we went to Kazakhstan... 


\section{G: Have you been asked to go to Gaza now?}

They didn't ask me, I asked them millions of times and I want them to send me there. I sent email to the manager Wadah and to my chief asking them to go there and I don't want any budget for danger places and these things because it's my duty to be there. Our journalists there work 24 hours. And I can feel, I can imagine, to time to eat, to sleep, just work 24 hours. I told them and he thought I was angry or upset because I said: we have to go there, we have to help them because they can't keep working 24 hours a day and we juts keep seat down here and eat and watch tv, just thinking 'it's unfair what happened there'. We have to move there, we have to do something. First we have to help our colleges. Second we have to be in the field to record everything because it's part of the history. And for me as a person history is the point. The history is something so important, specially for what we are filming now. Don't think about today, or tomorrow, just look forward. One day someone will use this tape.

G: What did they say to you?

Oh, the borders are closed and he said what I supposed to do, send you by parachute? I have to be patient and we will see. But for me, in the first chance I will be there. And now I am stand by, everything is ready, I took visa to all the countries around Gaza, because we don't know which one will open before to move there. 


\section{APÊNDICE F}

Transcrição da entrevista concedida por: VAL, Mohammed - senior journalist (correspondent).

G: How do you see the growing up of Al Jazeera?

I joint Al Jazeera in 2001, significant, first September 2001 and you know what it means. 10 days later the big event was the turning point in Al Jazeera history. Before 11/09 Al Jazeera was much more a local channel speaking to Arab world. After September $11^{\text {th }} \mathrm{Al}$ jazeera changed immediately to an international channel. That was a big suddenly change in the history of the channel after only 6 years of its launch. So this channel began as a very ambitious regional project to give a free voice to Arab masses. It chocked the governments in the Arab world, it attacked attention everywhere around region but it never really attacked attention around the world before September $11^{\text {th }}$ because we had those exclusives access in Afghanistan, we were the only channel in Afghanistan from the other side of the world, and it gave us international fame and it continues also in Iraq and later on in other conflicts.

And basically what made Al Jazeera famous international was not just only access but the editorial line. Al Jazeera made its editorial policy not to shy away from giving all the views in any conflict just one view and that's what made it different from $\mathrm{CNN}$ and $\mathrm{BBC}$, because $\mathrm{CNN}$ and BBC tended always to give one view, that's the view of western governments. Al Jazeera decided to give a voice to those who are fighting on the other side of the each world, each conflicts, the victims of war, war in Iraq, in Fellujah or Afghanistan cities, we show the civilian suffering there and also give voice to Al Qaeda, because for us Al Qaeda is a part of the conflict, and you know, we have to give equal access and equal opportunity to Al Qaeda as well, and that's why we were accused of being the channel of Bin Laden, but that's because it's chocking for western audience and western governments to hear, to find a channel that gives voice to people whom they consider enemies. Usually they don't do that, they give voice only to themselves, they don't give voice to enemy.

If you are talking about technique side, I don't know, maybe they have more technology that we have, but if you are talking about editorial side, it's much easier here, because we don't have those restrictions which they have, we don't have governments here - the government of 
Qatar doesn't impose any restrictions on our coverage, so we fell free to cover issues the way we think they should be covered. That freedom gives us a lot of (???) conflicts covering the histories and covering from our on conscious feeling of what's right and what's wrong and most basically it never (???) from giving equal opportunity even to those whom we think that are enemies. When we cover Afghanistan we gave equal opportunity to George Bush as Osama Bin Laden, we don't distinguish between them, we gave equal opportunity each one speak on Al Jazeera as much as they wanted. And Americans were angry about that.

Tsunami - it was the most outstanding event that I covered since I joint Al Jazeera because it was the first time I found myself in a such (???) amount of human suffering and it made a lot to me. It was said, painful, but I was lucky to be there because it gave a lot of death to my journalism, journalist carrier, journalist experience.

G: In Al Jazeera, what kind of job you did, as an al jazeera reporter, that made this journalism different and changed your carrier?

Tsunami was an example because there are two types of coverage in tv: when you go to those conferences...I hate all those things, I hate diplomacy, I hate politics because its all lies... On contrary, when I cover human situations, like tsunami, when I go to Darfur, Afghanistan and cover the suffer of human beings and give them voice that's what I like, that is what changed my journalist carrier to the best because that's when I feel my humanity and I was able to make a difference...

G: In Al Jazeera do you think that you have this opportunity?

Very much. I've had it many times because I covered Darfur, Tsunami and Afghanistan and in all those countries I found myself in that lucky situation of being able to report about the suffering of civilians in the face of big powers. And I also covered Indian elections and it was amazing because when I was there I discovered that the poor Indians, even though they are marginalized they are able to change government.

G: which is the biggest challenge in covering a fact for Al Jazeera?

I think the biggest challenge for us is to be able to distinguish, cast away prejudices that other medias have accumulated over the decades about certain issues. When you are covering a history about what a lot of public opinion has already been built over years by BBC, CNN, Reuters, APTN, like the Palestinian issue, the biggest challenge is to be able to tell people what the was story really about. Like Gaza, for instance, in Palestine. If you listening to those 
media outlets, they will tell you the whole problem is about rockets launched by Hamas against Israelis, they never go beyond on that. For us, the challenge is to be able to go beyond that, give more background, more information to tell people that it's not about rockets, it's about over 60 years of occupation. These are the most challenge situation because people don't like to listen to things they are not used to listen to. If you talk about how Israel was created, how the jews migrated around the world, they don't like to listen to that. They find it strange, because they are not used to listen to it. They will think you are faking. But in other situations like Darfur, AP, Reuters, CNN, they never give you just a brief line of information about Darfur without giving you this tag saying: By the way, 300 thousand civilians have being killed in Darfur. But they never tell you anything like this about the Palestinian situation. So, our challenge, is to deal with news stories in a difference aspect and to be able to do that without rising a virgin or criticism (???) from our viewers, our audience, want to tell them the truth and it's very difficult sometimes.

How do you see the relationship between Arabs and the media, specially Al Jazeera?

Al Jazeera, it appeals to Arab masses. Wherever you go in Arab world people will talk about Al Jazeera. It goes without saying no, it's like a fact, a established fact, that Al Jazeera appeals to Arab masses expresses our voices. And that's what make us fell powered of what we are doing. And also that is what's making many governments angry of us, because, somehow, we are doing something they don't want to see happening: Arab voices expressing their voices and being able to criticize and perhaps rise in the face of despots which impose them by those regimes.

G: Can you see another channel that makes the same?

Since Al Jazeera was launched, since Al Jazeera became a model, for this kind of progress in Arab world, freedom of expression, many channels have tried to emulate Al Jazeera, to imitated it, like Al Arabiya, for instance, in Dubai, like several other channels, Al Ekhbariya in Saudia Arabia, almost every other country tried to establish a channel that can compete with Al Jazeera, or, at least, can imitate it. But I don't think there's any channel that has been able to reach the level we had reached in this aspect, a success that we achieved, I don't think there is another channel that has equal success so far.

G: Twelve years is such a short period to achieve this success.

When the idea is good, it can catch fire, in a very short time. That's what happened with Al Jazeera, because the idea was amazing, excellent. The first time that a channel, in Arab world, 
does not start its bulletins or its news shows with the activities of the ruling president. And that's the big change we made from day one, we did not do that. We began giving real news, from minute one. That was amazing.

G: Have you suffered censorship here?

Never in my life. Never here.

G: Never in your life or never here?

Never in Al Jazeera. In my life... you know, before join Al Jazeera, I was in the written press and of course I was working in some countries there are many things you can't talk. Morocco, Mauritania, in some of those countries there are many things you can't touch, many taboos. But in Al Jazeera, here, very few things are taboos.

G: Could you tell me one?

Well, it's very obvious. You don't touch religious, you don't blaspheme. This is not something imposed on you, we have our own limits, we have our own self censorship. Basically religious believes and certain types of things like this. I don't have other examples.

G: We can see that Al Jazeera packages are different, closer to the news. What do you need to do as reporter from Al Jazeera to make us feel like that, closer to the fact?

I think that the most important thing, the most important tool is try to be honest, try to be human, honest, simple. When you go to a situation, instead of listening to what he said, instead of reading about an event, you go and see with your own eyes, you try to people on the ground, you try to talk to as many people as you can, get a much variety rich (???). And then you try to construct your story out of those things, Al Jazeera stories always complex, which means there are all rich of angles. That's what create the intrigue, that's what create the excitement. Even here, when we cover Gaza, we also bring Israeli gas, we also quote Israelis in what's happening. We know where we stand, but it still doesn't prevent us from covering the other side of the story.

G: Mohammed Val vai mostrar pra gente um pouco do trabalho dele aqui na Al Jazeera English.

M: This is the "Inside Story". Remember that CNN show called... daily news program...this is the time that does it. 
M: I think you've seen this, our newsroom. I am going there to talk to the producer who is in charge of the latest pictures, I will ask her what is the latest, I will go and do a little update to my package. 


\section{APÊNDICE G}

Transcrição da entrevista concedida por: ZEIDAN, Sami- news presenter.

\section{G: How was the launch of Al Jazeera for you?}

SAMI: exalerathing. it was a great experience, I had the opportunity to be the face and the voice that launched the first words about Al Jazeera, so it was a great experience.

One of those things that you participated and you think to yourself: this is a historical moment that I am participating this is just another bulletin, this is a really turning point in broadcasting journalism. So it was a fantastic experience to be involved before the launch, and it was a fantastic experience to be involved in the launch and after the launch.

G: What do you think the viewers were expecting from Al Jazeera?

SAMI: I think that probably depends on where the viewers were. I imagine that viewers probably in the west and in the Europe perhaps had negative idea what Al Jazeera would be. I think many people probably had no idea what Al Jazeera is and I think the viewers perhaps elsewhere particular in the muslin world had a positive idea and expectation of what $\mathrm{Al}$ Jazeera would be. So I think probably expectations were different depending on where the viewers were.

G: But now with the English Channel the public is everywhere.

That's right, we are in all kind of satellites and we reach all around the world. I get a lot of feedback as a presenter. The feedback I get is incredible positive. I'm not saying that because you're interviewing me, but is incredible when I go and check my email each day and on facebook each day the amounts of people who adding me and sending me comments saying we saw this interview that you did or we saw your coverage of this event, we saw you live in the field, it surprises me people remembering things that I'd forgotten sometimes. The feedback from viewers is incredible positive, people happy that there's a channel that offers an alternative perspective to what they get in the mainstream media which is almost became like its many(?), like the same opinion, the same approach, the same perspective, the same culture context to story telling almost in every station in the world now, it's almost like culture itself has fallen victim to industrialization and mass production. Just like everything is being mass produced. You go into one shop and you go into another and the products are 
looking increasingly similar. People say: this is made in China. China is making everything. In terms of culture products everything is being made in a western atmosphere. So I think $\mathrm{Al}$ Jazeera provides people with a refreshing different culture context to story telling and to news. I think people welcome that, from the feedback that come to me, at least.

G: I was imaging that Al Jazeera English was similar to the Al Jazeera Arab channel and nowadays I see that Al Jazeera English is similar to $\mathrm{CNN}$ and $\mathrm{BBC}$, very western also specially in the way of broadcasting. How do you think people see it?

S: I don't know. Maybe in terms of television production yes. Television production style is very different from Al Jazeera Arabic, in terms of types of stories that we cover our focus is more global whereas Al Jazeera Arabic is more regional, but I think the spirit is the same between Al Jazeera Arabic and Al Jazeera English and I think we are very different from $\mathrm{BBC}$ and $\mathrm{CNN}$ on some of the big stories that we cover. Just to give an example right now the War in Gaza. I got a phone call yesterday from someone whose being a critical of Al Jazeera, he's always looking for the things to criticize us, he was very positive yesterday saying: your coverage has been so different from the $\mathrm{BBC}$ and from the $\mathrm{CNN}$, the way that you've tackled stories, the way you've interviewed (?) persons, types of images that we've showed in amount of coverage we've given to human stories, is completely different on all those fronts from other channels. So I think we are a mix, maybe in terms of production style, yes, a production style is not like Al Jazeera Arabic, it is more close to western networks, but I think the contain isn't always the same as western networks. I don't wise we lose our reason on that... I think (???) that we are looking at things not on perspective all of the western frame of mind, and not from the perspective of the western culture, we're looking at things from the perspective of the voice of the south, which is not always heard, and doesn't always get the opportunity to frame the history in most of the media, international media at least.

G: Why don't you do the same as Al Jazeera Arabic nowadays: 24 hours a day talking about Gaza?

S: Maybe because... first of all, it's important to point out a lot of hours are diverted to covering in Gaza, you're right, it's not 24 hours a day but when I've been anchoring the last two weeks, I anchor the main one hour news show, and on one hour news show, maybe 40 minutes will be about Gaza and maybe 20 minutes will be about news from around the world. And the reason is that we are, our channel is more international one rather than the regional one. So we still want to give you some news about what's happening elsewhere in the world, 
in particular important developments going on elsewhere, we cant make the hole news show entirely only about Gaza. Because I think people, they want to know what's going on about Gaza, but 30, 40 minutes is probably enough for them, they also want to know what's going on somewhere else. So we go somewhere else, we came back and update. So that's why we're kind of different. Al Jazeera Arabic of course is broadcasting to the Arab world, not to a global audience. Even the Arab communities and the Arabs that reach outside the Arabs world are direct to what Arab speakers, so are looking primely an Arab audience, whereas we are broadcasting to a much bigger amount audience, who have other interests.

G: How much correspondents do you have and what kind of problem do you deal with them?

We have correspondent maybe 4 or 5 on the borders of Gaza and two inside. The borders inside Gaza I think the main challenge for them, first of all I would like to say I think the fact that we have correspondents inside Gaza makes our coverage so different and so distinct from all the other channels because the other international broadcasters they don't have correspondents inside Gaza so that gives us the ability to get pictures that you would not likely to see on other channels because they are not there, of the aftermath of the strikes, of the civilians suffering, of the situation in hospitals, of the situation in schools which have been hit, of the situation even in shops, how do the people go and get food now? ... so this life in Gaza is what we are able to get. The challenge is working in wars, which is when is it safe to go out and film, or when it is not? Of course the challenge of keeping our correspondents safe from home, protecting their lives because all kind of buildings are been hit... this is a challenge, safety and security, things also challenge in terms of restrictions which have place in the media... but despite that I think that what you will see on Al Jazeera is something you will not see, will take you further another channels can take you.

G: Do you have problems to communicate with tem?

S: we so far have been blessed that we have been able to get up a lot of lives, life shoots where we can see as well as hear our correspondents. They have found a way, they prepared, we have a good team that is always thinking ahead and they prepare for challenges and problems in advance and we have in particular a very capable producer that is always thinking ahead... So I think we've been able so far to make sure that we can operate without to many destructions. Phone line is a problem is Gaza, as usual, having a war going on doesn't make it easier, they face, of course, personal challenges, living in a city where the infra-structure is being hit is not easy, little things like availability of water, availability of electricity, which in 
the winter of course becomes even more important, these facts like this are difficult things to live with even if you're just a civilian (?) if you're also a journalist and has to work.

What about on air?

S: No, on the shows that I've anchored I remember one occasion where we lost our signal. There have been even few times where shells have landed very close to our correspondents while they were on air. And there was one time one of the press buildings, it was not all building but next building it was hit. So that causes panic and that causes impact, but it didn't cause us to lose transmission or broadcasting ability from Gaza.

G: How is to make journalism on Al Jazeera, specially considering you experience before join Al Jazeera, do you thing you do here something very different?

S: Yes, definitely, that's why I joint Al Jazeera, it was the attraction of doing something different. And for me in particular because of my own personal background being a product of a mixing of different cultures and influences. I guess I never already fit into the main stream of anywhere. When I went to work for mains stream, for westerns channel - all the channels I have worked for were western channels - I always felt that there was a dominate culture which carried with it (?) that couldn't really see unless you're looking at things from outside of that culture context and framework. I don't think it's intentional, it's just the way we operate as human beings, we are all brought up with in a culture and (?) our own culture eyes that we can see the world. There's no such thing as an objective par of eyes that we just became journalists and we become all of the sudden objective and I can see the world different from everybody else. Everyone see the world from their own eyes. And when you have a news organization that is made up of people from the same culture background I think the nature product of that is that they will see the world from that culture context. And the nice thing for me here in $\mathrm{Al}$ Jazeera is that this represents such a difference in terms of culture starting point, that we will not going to accept a culture starting point... the cultural norms and values and stereotypes of the north and western atmosphere, that we are going to see the world from a different perspective.

G: How do you find the others doing the same, the others who create channels similar to Al Jazeera?

S: I haven't seen anybody do that yet. I don't see anybody who's broadcasting in English from sort of non-western framework. Yes, it may happen in the future and when it does I think let it be the viewers to judge the products of the channels. But it's not something that I 
fear. When you look to the flow of information in the world, it goes primordially in one direction: from north to south. So the more channels that can come and reverse that flow or contribute to the reverse of that flow the better in my mind. I don't think if another as launch necessary should compete with Al Jazeera but can complement. You have in South America Hugo Chavez, his channel which is trying to broadcast regional too. So I think the more people and broadcasters try to themselves tell the stories of that part of the world I think is healthy. I don't think it's a threat to Al Jazeera.

G: You're half English and half Arab. How do you find the newsroom with a lot of Americans, British, anchors or producers...

I think we have a lot of diversity, in terms of staff in general, we have lot of staff from the West as well. I think the important thing is to look at each person's background and they're understanding in that culture... If you look at me, for example, on paper, my nationality is British, but when you look at me perhaps as a person what I've been exposed to in growing up with, then you will probably agree I don't fit the mainstream box. So that's the important thing, I think it doesn't mean that we are in the end of game in terms of diversity, more diversity will be welcome. It always welcome to get more and more people from different parts of the world. When you work in a news organization its constant, there's never a day you would say the mission is done. There's never a day you fly on that aircraft like George Bush and say the mission is accomplished, I think is working progress forever, is how to diversify or how to review yourself everyday and try to recommit yourself to your view statement.

G: Aren't you afraid of loosing this features when you have more western journalists in your staff?

It's something that we monitor ourselves and that is the editorial output of the channel, is our collective responsibility and I think many of the people who joint here they what they were doing when they joint Al Jazeera. This is a brand and a name that set firmly in the certain atmosphere. I would be surprise if you find anyone where who thought when joint Al Jazeera English they thought was joining a mainstream US or British channel. So I think everyone who's came is aware of that and understands here you have to look outside of the culture framework and box of the mainstream Western culture. How much or how far we achieved that's for the viewer to judge.

G: Have you had any problems with censorship here? 
S: No, we don't have censorship here.

\section{G: Even self-censorship?}

S: I don't know, that each personal. I think all right: it's much more danger thing but to be honest I've witness self-censorship in every place I've worked. I, personally, haven't felt here but I am sure it probably exists in some shape or formal manner. I think that I've seen in every news I've worked, four major networks of the world, there's self-censorship, people always afraid to suggest and look at the story from this angle or that angle. That is more constant challenge to work with and I don't think there is an instant or magic solution for that other than try always to encourage people to say what they think. The channel may not always adopt what you think but to encourage people to say what they think is a challenge.

G: What about the royal family. Are they inside the newsroom?

S: Are they? I haven't seen. No, I'm not aware of any single member of the royal family working in the newsroom. As far as I know we don't have any single person from the royal family in the management, like director of news or director of programming - he is Australian - the head of output, the head of input not of them are Qataris. I don't think we have Qataris in the direction of departments. There isn't that interference. Just let me give an example: we had a guest once who came here and he told me - I was about to interview him - and he told me: I want you to ask you this questions because the Emir wants you to ask this questions. I told him: sorry, first of all, I'm a journalist, so what you want to say it's up to you, but what I want to ask I am afraid... that's my job. They try to put pression on you maybe. This is the way we operate, we don't take instructions from anyone, neither has anytime the Emir try to give us instructions, or tell us to do this and to say that. That's the way we operate.

G: Which was the most important cover you've participate here besides the launch?

S: I think the Gaza War. The launch and Gaza War - I think the two key events of our history, Al Jazeera English, the two most important things for us. The launch was our creations but Gaza War has turned a lot of attention to what's us, and I think we have excelled in the way we have covered the Gaza War, both in the ability in terms of access, to take people places where they can not go in other channels, but also for our editorial approach to the history has been so much different. In some parts of the world, the idea of balance has been misunderstood where by to some people the idea of balance means to equate and occupied person with the occupy. (?) I think in some minds that line has become fasy and I think one of the things we excelled is showing the reality as it is, not as people would like it to be because 
any sort of cultural historical baggage that they have, that they are unable to approach both sides of the conflict with accuracy because of maybe cultural historical baggage that some people have. I think we've been able to deal with, in terms of Gaza, the reality as it is. I remember the first few days when the rockets were falling we have correspondents in... showing the Palestinian rockets falling what the damage it was, we've given time for Israeli spokes people to come and explain their side of the story but at the same time we've dedicated a lot more time to show the destruction in Gaza because that is where the majority of the destruction is, that's the reality. I think to try and portray both sides as equal means you being unaccurate. One side you have a very advanced modern army, that is actually occupying another land. And the occupied people are baring the brunt in terms of casualties and in terms of the restrictions... I think for those journalists who think that to be balance means to portray both side as equal is unaccure, that's not my job, that's the job of propaganda to make one side look better than the other. My job is simple to portray the reality, that's one of the things that we have done very well on the War in Gaza, that's why people appreciate our coverage.

G: We see a lot of strong pictures on Al Jazeera. Why do you show everything and not edict?

S: We do have standards, it's not like we just show every pictures that comes, believe me there are a lot of pictures we don't show. But of course we are governed by agreements who regulates in terms of what pictures we can show, we have to honor those agreements. But you are right: we do show more of the civilian's causalities than perhaps some of the other international English broadcasters. And I think this because we feel responsibility to show as much as we can of the reality as long as it's tasteful and appropriated for our audience. We do show graphic images we usually accompany with the warning that the pictures which people are about to see in the following report are very graphic, you may find it disturbing, you give people the opportunity if they don't want to see they can turn it away. But I think there are many people who actually want to see as much as they can of the reality. And I think that is important because otherwise when you go to far in restricting the images you can be accused of sanitizing war. And this is what a lot of people even on the West are angry with some the media about. That the media have been controlled some of the recent conflicts by powerful governments who manages to sanitize the war. So I think we want to avoid being put into that category. People are not stupid, people know when all you see is images of soldiers launching shells and rockets but you never see what happened when they fall. People realize that the media has been controlled. I don't think it's possible anymore to control those images. People 
will get images on internet. We are now lining in a era of...of the individual. People will film thing and send throw. So I think we recognize our responsibility as journalists to present as much as we can of the reality.

G: What do you think about Brazil or Brazilian coverage or Latin America...

S: To be honest I haven't seen a lot of Latin America...I haven't have the opportunity to see how Latin America stations have covered war. I would like to. 


\section{ANEXO 1 - MAPA DO CATAR}

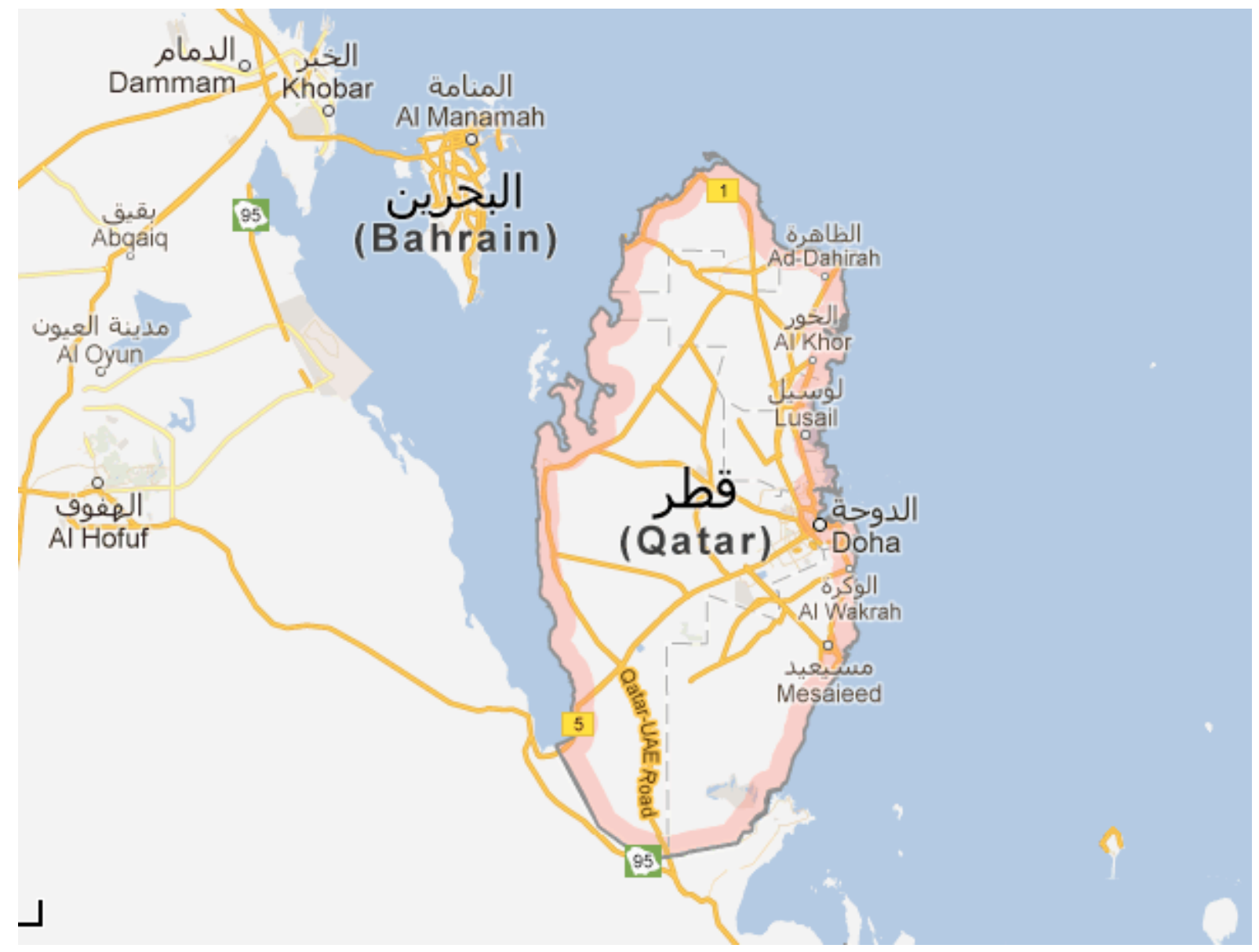

Fonte: maps.google.com 
ANEXO 2 - MAPA DO GOLFO

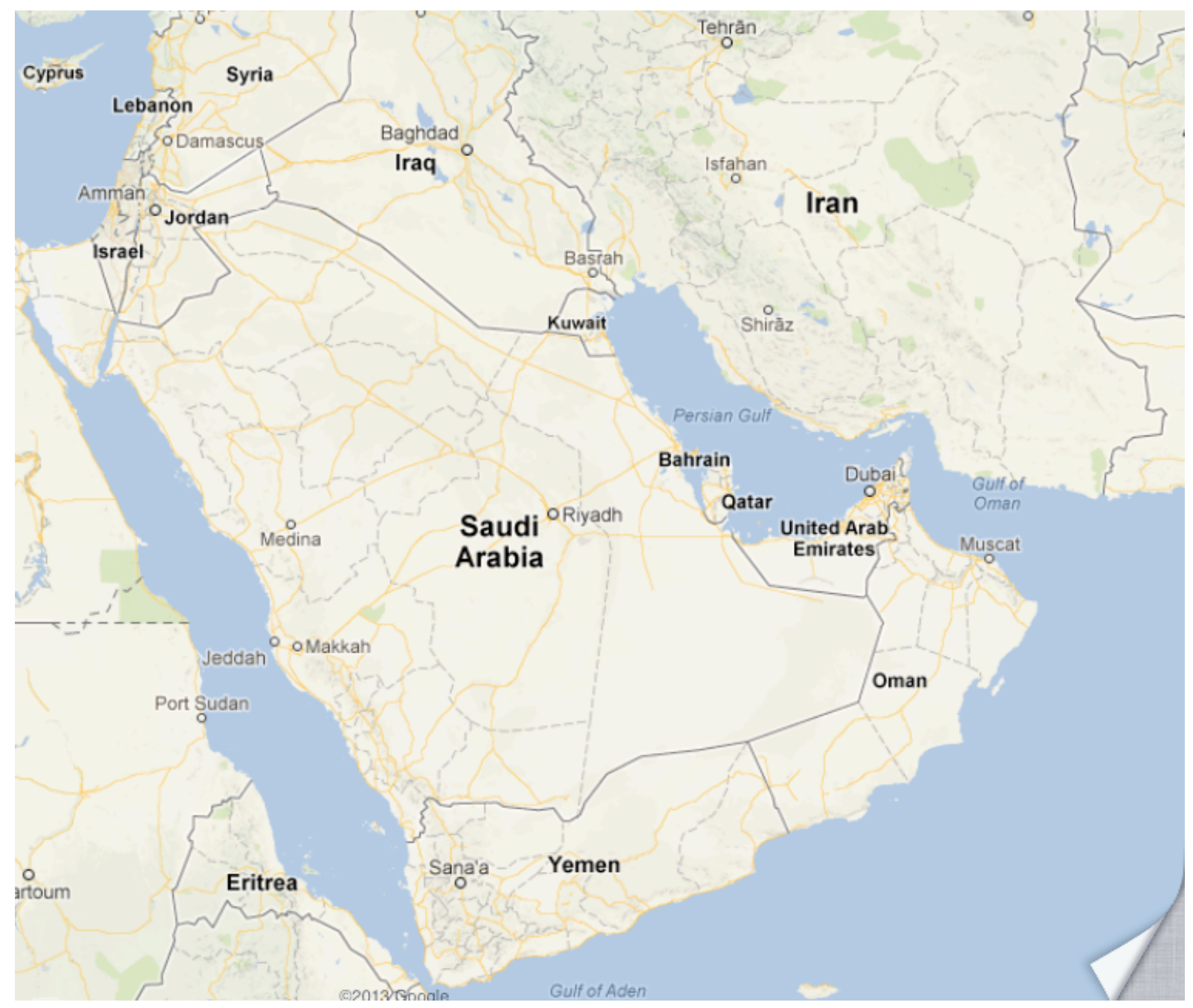

Fonte: maps.google.com 


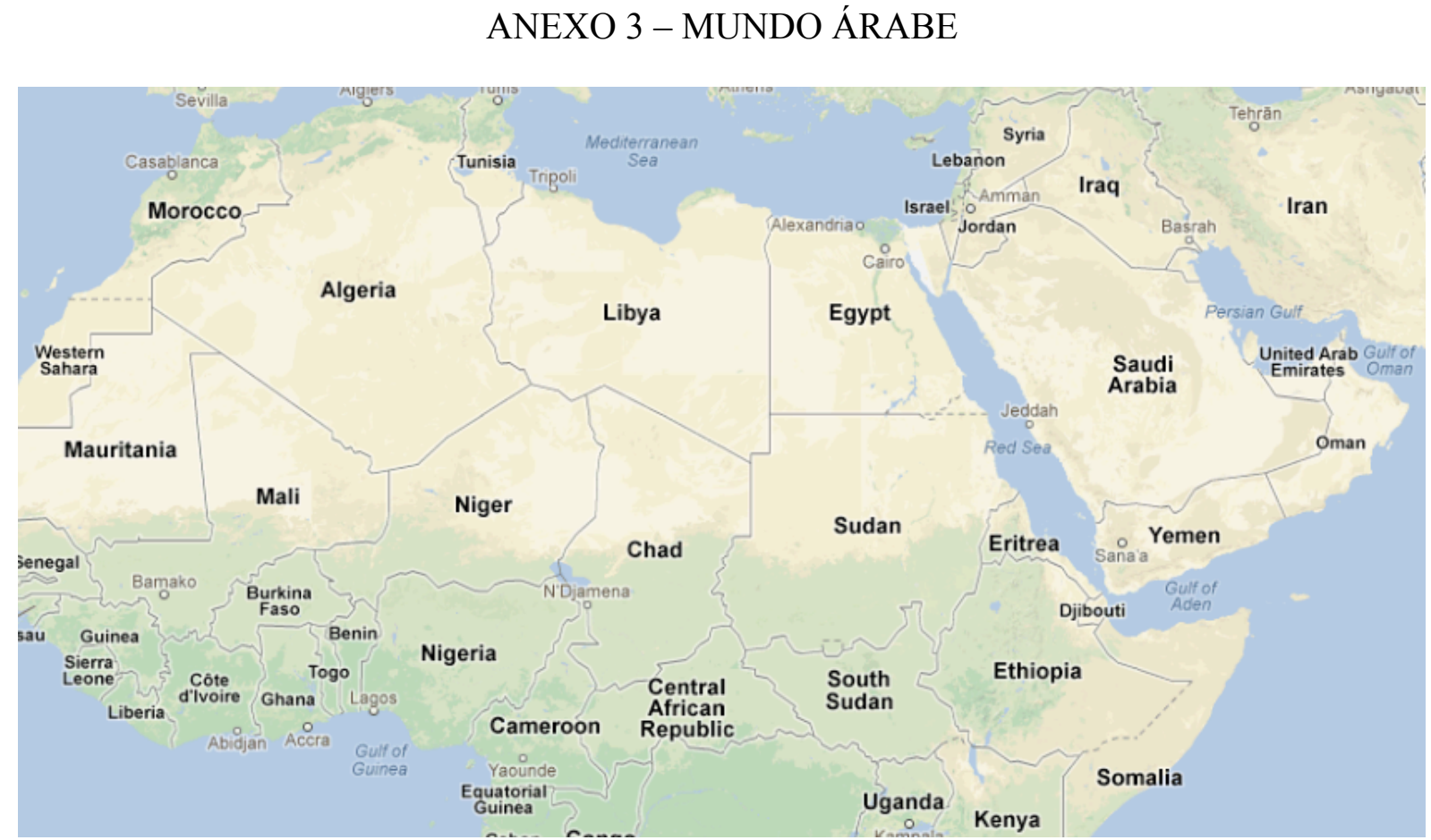

fonte: maps.google.com 